\title{
Bedrock Geology of
}

the Cupsuptic and

Arnold Pond Quadrangles,

West-Central Maine

G O L O I C A L S U R E Y B U L L T IN 1346

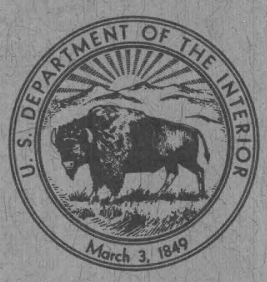





\section{Bedrock Geology of the Cupsuptic and Arnold Pond Quadrangles, West-Central Maine}

By DAVID S. HARWOOD

G E O L O G I C A L S U R V E Y B U L L E T I N 1346

Description of the geology of folded and metamorphosed lower Paleozoic rocks in the Boundary Mountain anticlinorium 


\section{UNITED STATES DEPARTMENT OF THE INTERIOR}

ROGERS G. B. MORTON, Secretary

GEOLOGICAL SURVEY

V. E. McKelvey, Director

Library of Congress Catalog-card No. 72-600305

For sale by the Superintendent of Documents, U.S. Government Printing Office Washington, D.C. 20402

Stock Number 2401-02205 


\section{CONTENTS}

Page

Abstract_...

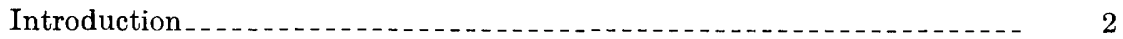

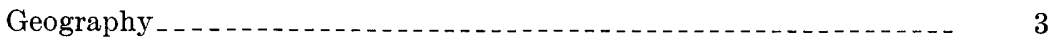

Previous work

Present work

Acknowledgments_.

Stratigraphy _..._._._._. 8

Rocks of pre-Silurian age

Aziscohos Formation.

Albee Formation_._. 10

Portage Brook Member.

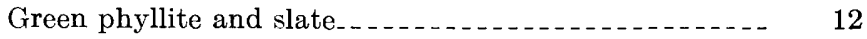

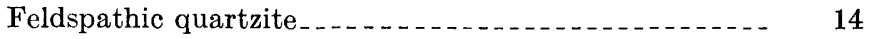

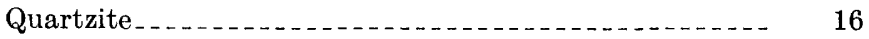

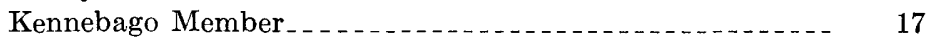

Red slate

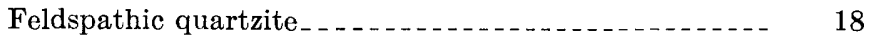

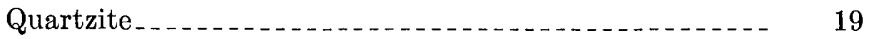

Black slate and greenstone._._._.................... 19

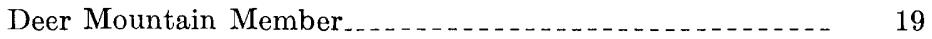

Black phyllite

Green slate and phyllite and greenstone.......... 20

Purplish-gray phyllite.............................. 21

Dixville Formation _._._.

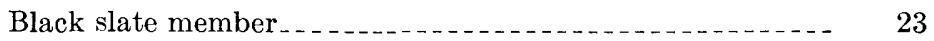

Lenticular units in the black slate member............. 24

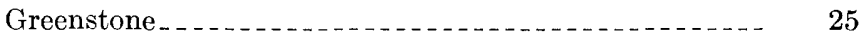

Calcareous lithic graywacke..._._._._.......... 25

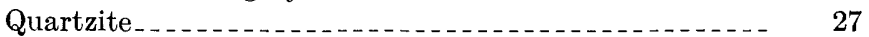

Magalloway Member._._. 28

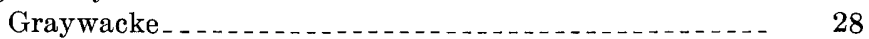

Green and purplish-gray slate..................... 30

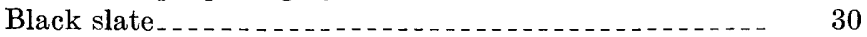

Biotite gneiss_._._._. 30

Lenticular greenstone units._. 31

Rocks of Ordovician and Silurian age._._.

Black hornfels and amphibolite._._._._._._._._._._._. 33

Quartzite and gray hornfels.

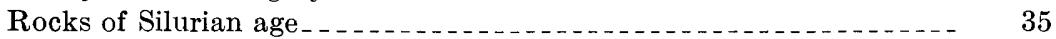

Rangeley Formation. 36

Polymict metaconglomerate member............ 36

Quartz-pebble metaconglomerate member._........ 38

Slate and quartzite member. 38 
Stratigraphy-Continued

Rocks of Silurian age-Continued

Unnamed rocks in the vicinity of Parmachenee Lake _._._._. 39

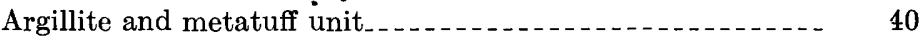

Metaconglomerate and quartzite unit.

Argillaceous metalimestone unit.................. 41

Arenaceous metalimestone unit._.

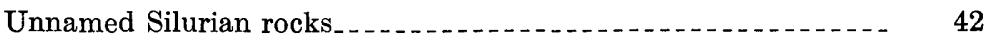

Polymict metaconglomerate

Calcareous slate and metalimestone.................. 44

Unnamed Silurian and Devonian rocks..................... 44

Metamorphosed felsic tuff $\ldots \ldots$. 45

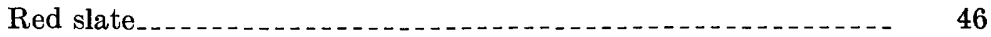

Green slate and metasiltstone....... 46

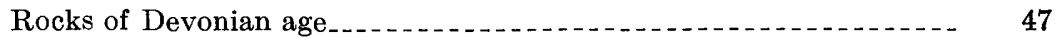

Seboomook Formation

Intrusive igneous rocks_...

Ordovician ultramafic and mafic rocks_._.

Serpentinite.................... 50

Pyroxenite

Metadiorite

Gabbro $\ldots$

Granodiorite

Devonian intrusive rocks.

Quartz monzonite

Granodiorite

Intrusive felsite....... 59

Post-Devonian intrusive rocks__._. 59

Lamprophyre dikes.

Metamorphism_....... 60

Regional metamorphism

Contact metamorphism

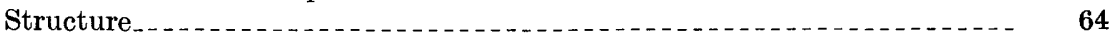

Acadian folds in the Silurian and Devonian rocks._.

Acadian folds in the pre-Silurian rocks

Taconic unconformity

Major Taconic folds

Major faults

Faults associated with the Deer Brook syncline

Faults in the Silurian rocks east of Parmachenee Lake...... 72

Fault at Little Kennebago Lake._... 73

Fault at Daddys Ridge

Fault at Johns Pond

Other faults

Minor structural features.

Foliation

Foliation in the igneous rocks. 75

Slip cleavage

Minor folds

Linear features. 79

Economic geology

References cited

Index 


\section{ILLUSTRATIONS}

[Plates are in pocket]

Plate 1. Bedrock geologic maps and sections of the Cupsuptic and Arnold Pond quadrangles, west-central Maine.

2. Geologic map and structure section of the Kennebago Member of the Albee Formation at Kennebago River gorge, Cupsuptic quadrangle, west-central Maine.

Figure 1. Index map of parts of Maine, New Hampshire, and Quebec showing location of the Cupsuptic and Arnold Pond quad-

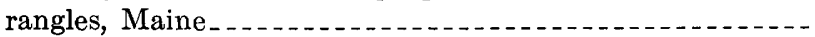

2. Photograph of stringers of quartz in green phyllite of the

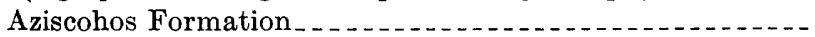

3. Photograph of chip-rubble weathering of the Portage Brook Member of the Albee Formation.

Page

4. Photograph and photomicrograph of pinstripe laminations in feldspathic quartzite of the Albee Formation .............

5. Ternary diagram showing the classification of graywacke and plots of graywacke samples from the Dixville Formation...

6. Photomicrograph of arkosic graywacke of the Magalloway Member of the Dixville Formation . . ..............

7. Photomicrographs of contact-metamorphosed rocks of the Albee Formation in the aureole of the Cupsuptic pluton...

8. Photograph and photomicrograph of slip cleavage crossing foliation in rocks of the Albee Formation ............

9. Photograph of minor folds in the Albee Formation........

10. Photograph of hogback fold in the Kennebago Member of the

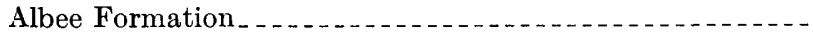

11. Sketches of refolded minor folds in the Albee Formation .....

\section{TABLES}

TABLE 1. Representative estimated modes of the Albee Formation in the Cupsuptic quadrangle............................

2. Measured modes and ternary compositions of graywacke from the black slate member and Magalloway Member of the Dixville Formation, Cupsuptic quadrangle

3. Representative estimated modes of the serpentinized ultramafic rocks and metadiorite from the Cupsuptic and Arnold Pond quadrangles.

4. Representative modes of Ordovician gabbro and granodiorite from the Cupsuptic quadrangle.

5. Representative modes of Devonian intrusive rocks from the Cupsuptic and Arnold Pond quadrangles.

6. Semiquantitative spectrographic analyses of selected sulfiderich rocks from the Cupsuptic-Arnold Pond area..........

7. Combined fire assay-atomic adsorption determinations for gold in selected sulfide-rich samples from the Cupsuptic-

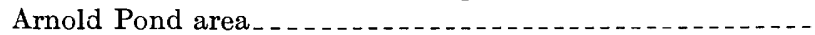




\title{
BEDROCK GEOLOGY OF THE GUPSUPTIC AND ARNOLD POND QUADRANGLES, WEST-CENTRAL MAINE
}

\author{
By David S. Harwood
}

\begin{abstract}
The Cupsuptic and Arnold Pond quadrangles constitute an area of about $\mathbf{2 6 5}$ square miles in west-central Maine about 3.5 miles east of the New Hampshire State line. The northern limit is the international boundary between the State of Maine and the Province of Quebec. Virtually all the area is forested, and logging is the principal industry.

The map area spans the northeast-trending Boundary Mountain anticlinorium, the principal structural feature in west-central Maine. A sequence of slate, metagraywacke, and metavolcanic rocks, at least 20,000 feet thick and ranging in age from Early Ordovician to late Middle Ordovician, forms the core of the anticlinorium in the central part of the project area. These rocks are unconformably overlain to the northwest and southeast by metaconglomerate, metalimestone, and slate, which range in age from Early Silurian to Early Devonian.

The pre-Silurian sequence has been divided into three formations. The oldest, the Aziscohos Formation, is exposed in the southwest part of the Cupsuptic quadrangle and consists of green phyllite that contains abundant pods and stringers of white quartz. The overlying Albee Formation has been divided into the Portage Brook Member, composed of green slate and phyllite and laminated quartzite ; the Kennebago Member, composed of red slate and laminated quartzite; and the Deer Mountain Member, composed of black, green, and purplish-gray slate and phyllite containing only minor amounts of arenaceous rocks. The Albee is overlain by the Dixville Formation, which includes a lower black slate member that contains lenses of greenstone, quartzite, and calcareous graywacke, and the overlying Magalloway Member, composed of feldspathic graywacke that contains lenses of mafic volcanic rocks. In the southeastern part of the Cupsuptic quadrangle, the black slate member of the Dixville contains graptolites of late Middle Ordovician age; the underlying formations contain no fossils and can be dated only tentatively as Early to Middle Ordovician by correlation with lithologically similar rocks of that age found elsewhere in northern New England.

In the southeastern part of the area, the Dixville and Albee Formations are unconformably overlain by the Rangeley Formation which consists of polymict and quartz-pebble metaconglomerate members overlain by a slate and quartzite member. The basal part of the Rangeley is Early Silurian (late Llandovery) in age. To the northwest near Parmachenee Lake, the Dixville is overlain by unnamed Silurian rocks which consist of an argillite and metatuff member, a metaconglomerate and quartzite member, an argillaceous metalimestone member, and an arenaceous metalimestone member that contains Late Silurian (Pridoli) fos-
\end{abstract}


sils. The northwest flank of the anticlinorium is marked by discontinuous patches of polymict metaconglomerate and of calcareous slate and metalimestone tentatively dated as Late Silurian by fossil fragments and by correlation with similar rocks of that age found on strike to the northeast. The calcareous slate and metalimestone are overlain by felsic metatuff and red and green slate units of Silurian and Early Devonian age, which are in turn overlain by well-bedded gray slate and quartzite of the Seboomook Formation of Early Devonian age.

The stratified rocks are cut by seven small plutons composed of sepentinite, serpentinized ultramafic rocks, and metadiorite; by three small plutons of granodiorite; and one small pluton of gabbro. These plutons are tentatively dated as Middle or Late Ordovician by field relationships. Larger plutons of biotitemuscovite quartz monzonite and hornblende-biotite granodiorite and several small bodies of instrusive felsite all of Devonian age cut the pre-Silurian, Silurian, and Devonian rocks and locally intrude and metamorphose the ultramafic plutons. Four small lamprophyre dikes cut the Devonian plutons and are tentatively datcu as Late Triassic or Early Jurassic.

The pre-Silurian rocks were folded into west- or northwest-trending major folds, uplifted, and deeply eroded during the Taconic orogeny, which is dated in the map area as Late Ordovician to earliest Silurian. The major deformation, however, occurred during the Acadian orogeny and formed northeast-trending, gently plunging folds in the Silurian and Devonian rocks and a complex pattern of northeast-trending major folds superimposed on northwest-trending Taconic folds in the pre-Silurian rocks in the core of the Boundary Mountain anticlinorium. A pervasive, generally northeast-trending foliation found in all the stratified rocks is parallel to the axial surfaces of the Acadian folds. This foliation, bedding, and minor folds and their related linear features are deformed locally by north-trending, vertical, slip cleavage tentatively related to the intrusion of the major Devonian quartz monzonite plutons.

The stratified rocks are in the chlorite zone of regional metamorphism. Around the Devonian quartz monzonite plutons, however, the rocks have been contact metamorphosed to biotite, andalusite, and sillimanite grades. The regional and contact metamorphism is attributed to the Acadian orogeny, but the pervasive foliation in the chlorite-grade rocks is obliterated in the sillimanite-grade hornfels, indicating that the contact metamorphism and thus intrusion of these plutons postdated the regional dynamo-thermal metamorphism.

Veinlets of chalcopyrite and sphalerite occur locally along the trace of an inferred thrust fault on the southeast side of Thrasher Peaks in the northwest part of the Cupsuptic quadrangle. Disseminated grains of chromite occur locally in amphibolite associated with sepentinite north of Arnold Pond. Asbestos and talc veinlets are found scattered throughout the small serpentinite plutons, but they do not appear to be present in sufficient amounts to be mineable.

\section{INTRODUCTION}

Prospecting for asbestos and sulfide deposits in the Cupsuptic and Arnold Pond quadrangles and adjacent areas in the early 1950's focused attention on the lack of detailed geologic knowledge in this part of Maine. Although reconnaissance studies were made in the latter half of the 1800 's, the first detailed investigations of stratigraphy and structure were made by Boucot (1961) and Albee and Boudette (1972). Albee (1961) first defined the Boundary Mountain 
anticlinorium, and Cady (1960) discussed the lithologic similarity between rocks within it and those on the east flank of the Green Mountain anticlinorium in northern Vermont and adjacent Quebec, which contain valuable asbestos deposits and small base-metal sulfide deposits. Detailed mapping of the stratigraphy and structure of the rocks in the Cupsuptic and Arnold Pond quadrangles was considered essential to any economic investigations in the area, and data obtained in this study have provided a link between detailed mapping in northern New Hampshire by Hatch (1963) and Green $(1964,1968)$ and mapping in west-central Maine, either completed or in progress, by Albee and Boudette (1972), Moench (1971), E. V. Post, G. M. Boone, E. L. Boudette, and C. V. Guidotti.

\section{GEOGRAPHY}

The Cupsuptic and Arnold Pond quadrangles (fig. 1) comprise an area of about 265 square miles, the western edge of which is about 3.5 miles east of the Maine-New Hampshire State line. The northern border is the international boundary between Quebec and Maine, which in this region is the major drainage divide of the Boundary Mountains (Fenneman, 1938) that separates streams flowing north to the St. Lawrence River from those flowing south to the Atlantic Ocean. The Magalloway River (fig. 1) flows south along the western border of the quadrangles through Parmachenee and Aziscohos Lakes to Umbagog Lake near Errol, N.H. The Cupsuptic and Kennebago Rivers (fig. 1) flow south through the central and eastern parts of the map area, respectively, and enter Cupsuptic Lake. Cupsuptic Lake drains southwestward through Mooselookmeguntic Lake and Upper and Lower Richardson Lakes (fig. 1) to Umbagog Lake. The Androscoggin River (fig. 1) flows west from Umbagog Lake, then south and east to the Gulf of Maine. A local drainage divide in the eastern part of the Arnold Pond quadrangle separates the north-flowing headwaters of the North Branch of the Dead River, a major tributary of the Kennebec River, from the south-flowing Kennebago River (fig. 1).

The Magalloway, Cupsuptic, and Kennebago Rivers divide the Boundary Mountains into two belts of sharp mountain peaks and low ridges. Altitudes range from 1,467 feet at Cupsuptic Lake to 3,815 feet at White Cap Mountain (pl. 1), giving a maximum relief in the area of 2,348 feet. Local relief is 1,988 feet between Deer Mountain and Cupsuptic Lake, 1,928 feet between West Kennebago Mountain and Kennebago Lake, and 1,865 feet between White Cap Mountain and the Kennebago River. The most conspicuous topographic features are two essentially circular lowland areas in the center of the Cupsuptic quadrangle and a third in the eastern part of the Arnold Pond 


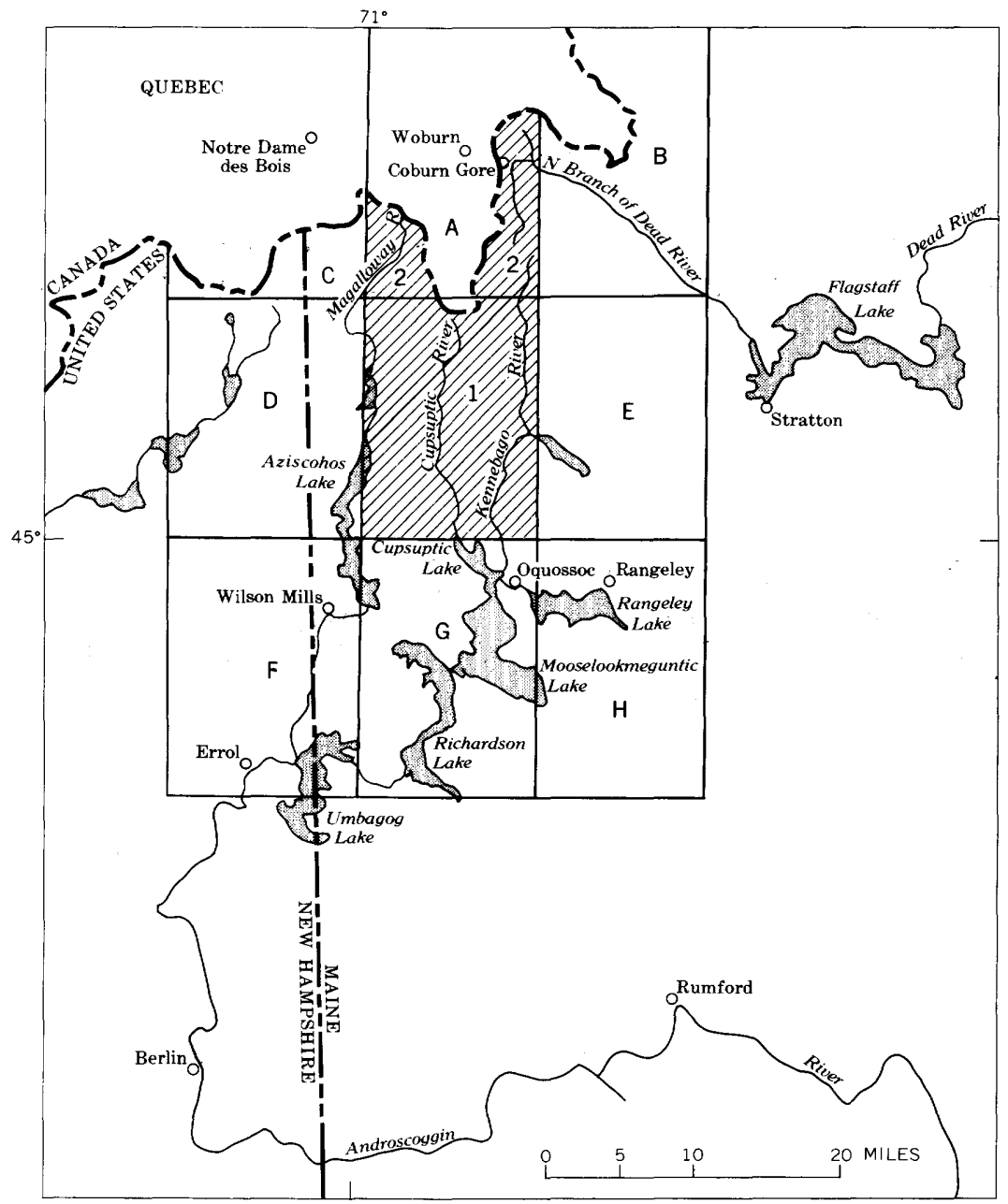

Frgure 1.-Index map of parts of Maine, New Hampshire, and Quebec showing the locations of the Cupsuptic (1) and Arnold Pond (2) quadrangles (shaded) ; Woburn area, Quebec (A); and Chain Lakes (B), Moose Bog (C), Second Lake (D), Kennebago Lake (E), Errol (F), Oquossoc (G), and Rangeley (H) quadrangles.

quadrangle. These lowland areas are underlain by granitic rocks surrounded by prominent mountains of more resistant hornfels. Low ridges of variable trends are by far the most common topographic feature; these reflect the trend of resistant bedrock units.

There are only 5 miles of paved road in the Cupsuptic quadrangle, where State Route 16, between Wilsons Mills and Oquossoc, Me. (fig. 1), arches around the northern end of Cupsuptic Lake. An ex- 
tensive network of gravel logging roads, however, provides good access to all but the most mountainous parts of the area. Several gravel roads, recently constructed as main haulageways for current logging operations and therefore not shown on the topographic map, have provided particularly valuable access. One such road extends from the southwest corner of the Cupsuptic quadrangle to Lincoln Pond (pl. 1); a second road crosses the area from Deer Mountain in the southwest to Little Kennebago Lake (pl.1) on the east. Several roads extend east and north from Parmachenee Lake to the upper reaches of the Magalloway and Cupsuptic Rivers. Many of the older gravel roads are not maintained and can be traversed only in a four-wheel-drive vehicle.

Access to the eastern part of the Arnold Pond quadrangle is provided by logging roads, such as the Beaver Pond Tote Road (pl. 1). The western part of the Arnold Pond quadrangle can be reached from Woburn or Notre Dame des Bois in Quebec (fig. 1) or via logging roads north from Parmachenee Lake.

The mapped area is heavily forested by thick stands of balsam fir and spruce in the swamps and on high mountain slopes and by more open stands of yellow birch, white birch, maple, and beech on the lower mountain slopes and ridges. The principal industry is logging of both hard and soft wood, under the direction of The Brown Company of Berlin, N.H., and various Canadian contractors. The Brown Company owns the principal parts of Parkertown, Lynchtown, and Parmachenee townships and buys standing timber selectively in the rest of the area from various landowners. Services related to logging, such as logistical support and road construction, are provided in part by local businessmen in nearby settlements. An important means of livelihood in the neighboring Rangeley area is providing accommodations, equipment, and services for an active hunting, fishing, and tourist trade and a growing winter sports business. The rivers, lakes, and woodlands in the mapped area serve as a recreation area for the sportsmen and tourists.

\section{PREVIOUS WORK}

Geological reconnaissance in the Cupsuptic area began more than 100 years ago when Stephenson (in Jackson, 1839, p. 191-205) travelled up the Magalloway River to verify the position of the Quebec Border. Mason (in Holmes and Hitchcock, 1862, p. 324-329) traversed Rangeley and Cupsuptic Lakes searching primarily for limestone for agricultural use. The atlas prepared by C. H. Hitchcock (1878) to accompany his account of the Geology of New Hampshire (1877) includes a geologic map of the Cupsuptic area that shows the broad outline of rock units presented in this report. Hitchcock's Lisbon Group, which corresponds 
roughly to the Albee Formation of Billings (1956), lies in a broad northeast-trending belt through the center of the quadrangle. The Lisbon Group on Hitchcock's map is overlain to the northwest and southeast by his Lyman Group, in part equivalent to the Ammonoosuc Volcanics and Partridge Formation of Billings (1956). In addition, Hitchcock recognized the rocks of Silurian age in the southeastern part of the Cupsuptic quadrangle.

Dale (1907) mapped the granite body in the northeast corner of the map area, but he did not show the quartz monzonite, mapped by Hitchcock, in the center of the Cupsuptic area, nor did he include this area in his discussion of the granite bodies of Maine.

The "Preliminary Geologic Map of Maine" by Keith (1933) has been superseded by the "Preliminary Geologic Map of Maine" compiled by Hussey and others (1967) which, to date, is the most complete and detailed regional synthesis of the geology.

Recent work in northern New Hampshire, particularly that of Billings $(1937,1956)$, Green $(1964,1968)$, and Hatch (1963), describes rocks on strike with those in the mapped area at equivalent or higher grades of regional metamorphism. Recent unpublished geologic work has been done by C. V. Guidotti in the Oquossoc quadrangle to the south and E. L. Boudette in the Kennebago Lake and Chain Lakes quadrangles to the east. Marleau $(1957,1959,1968)$ mapped the Woburn area (fig. 1) in the adjacent part of Quebec, and Moench (1971) has mapped the Rangeley and Phillips quadrangles to the southeast.

Discussions and maps of Cady (1960), Billings (1956), Albee (1961), Boucot (1961), and Boucot, Griscom, and Allingham (1964) present important regional stratigraphic syntheses and correlations in northern Vermont, northern New Hampshire, and northwestern Maine.

Post and Hite (1963) have recorded the content of citrate-soluble heavy metals and cold acid-extractable copper from stream sediment in the Cupsuptic and Arnold Pond quadrangles as part of a regional geochemical survey of west-central Maine. Gravity anomalies are indicated on the Bouguer gravity map of Maine by Kane and Bromery (1966), and the aeromagnetic anomalies in the Cupsuptic area are reported by Boynton and Gilbert (1964).

\section{PRESENT WORK}

Geologic mapping of the Cupsuptic and Arnold Pond quadrangles, carried out during the summers of 1963 through 1967, represents a total of 15 man-months in the field. Most of the mapping was done at a scale of 1:48,000 using standard pace-and-compass methods supplemented with readings from an aneroid barometer. In addition, a detailed paceand-compass map at a scale of about $1 \mathrm{inch}=1,500$ feet was made of the 
Silurian rocks east of Parmachenee Lake (pl. 1), and a second detailed geologic map ( pl. 2), at a scale of 1 inch $=200$ feet, was made by planetable methods for a half-mile section of the Kennebago River gorge between the dams at the outlet of Kennebago Lake.

Many outcrops, and in some areas the only outcrops, are exposed in the network of logging roads not shown on the topographic base maps surveyed in 1931 and 1932. These outcrops were located on high-altitude air photographs taken in 1958 and were transferred to the base map by measuring corresponding bearings and proportional distances from recognizable topographic or cultural features common to both the photographs and the map.

\section{ACKNOWLEDGMENTS}

It is a pleasure to acknowledge the cooperation of Mr. C. S. Herr, Vice President of the Brown Company, Berlin, N.H., and the supervisor in the Cupsuptic area, Mr. Alton Olsen, who granted access to private logging roads and took an active interest in the progress of the mapping. Access to private land and roads was also kindly provided by the Kennebago Camp Owners Association, the Megantic Club, and Mr. Wilford Gregoir.

Helpful discussions and the cooperation of E. L. Boudette and R. H. Moench, U.S. Geological Survey, C. V. Guidotti, University of Wisconsin, and J. C. Green, University of Minnesota, all of whom mapped adjacent quadrangles, are gratefully acknowledged.

The fossils discussed in this report were studied by W. B. N. Berry, University of California, Berkeley, R. B. Neuman and W. A. Oliver, Jr., U.S. Geological Survey, A. J. Boucot, Oregon State University, and R. M. Finks, Queens College. A. J. Boucot and R. B. Neuman discussed problems of regional correlations in the field and helped collect some of the fossiliferous rocks.

Special thanks are given to M. P. Billings and J. B. Thompson, Jr., of Harvard University, who reviewed field relationships and made helpful criticisms when part of this report was submitted as a $\mathrm{Ph} . \mathrm{D}$. thesis at Harvard University.

Field assistance was provided by Howard Day and Charles Thayer in 1963, Norman Dion in 1964, Frederick Hoffman in 1965, Edward Grew in 1966, and Graham Patterson in 1967. Thanks are offered to Douglas Rumble who provided valuable assistance for part of the 1965 season. The enthusiastic and able assistance of Carl Eastwood, Jr., of Rangeley, Me., offered without remuneration on weekends from 1963 to 1965 , is gratefully acknowledged. 


\section{STRATIGRAPHY}

The stratified rocks of the Cupsuptic and Arnold Pond quadrangles can be divided into two broad lithologic groups corresponding to two major chronological divisions. Rocks of pre-Silurian age-dominantly slate, metagraywacke, and greenstone-form a sequence about 20,000 feet thick deposited in the northern Appalachian geosyncline from Early Ordovician (?) to late Middle Ordovician time. Rocks of Silurian and Devonian age, ranging in thickness from 0 to 3,000 feet, are mainly polymict metaconglomerate, quartz-pebble metaconglomerate, quartzite, slate, and metalimestone that rest unconformably on the pre-Silurian rocks. Intrusive rocks underlie about 10 percent of the area.

The sequence of stratigraphic units was determined from primary depositional features such as graded bedding, crossbedding, channeland-fill structures, and volcanic pillow structures located at the contracts of map units. These features are not present or clearly distinguished everywhere in the area; therefore, the stratigraphic sequence depends, in part, on the careful tracing of distinctive lithologic units from areas where the order of superposition is known. Fossils found in the Cupsuptic area date some of the units and set broad limits on the age of adjacent units, but they are too scarce and too widely separated to use in determining the stratigraphic sequence or in establishing or refuting the facies changes suggested by the discontinuous pattern of some lithologic units.

The thickness of map units, especially those of pre-Silurian age, is not well known because these rocks have undergone intense deformation, and even partial sections free of structural repetition are not available. Furthermore, the outcrops are so widely scattered that reliable measurements across even the least deformed areas are impossible. The thicknesses of units, therefore, have been determined from measurements taken from the geologic map and cross sections and depend on the interpretation of the deformation pattern.

\section{ROCKS OF PRE-SILURIAN AGE AZISCOHOS FORMATION}

Green (1964) proposed the name Aziscohos Formation for rocks believed to underlie the Albee Formation in the northeastern part of the Errol quadrangle (fig. 1). He divided the Aziscohos into a lower part that consists of carbonaceous and sulfidic black phyllite and schist and variable amounts of amphibolite, biotite-plagioclase-quartz gneiss, quartzite, calc-silicate rock and quartz-spessartite rock, and an upper part that consists of green to silvery gray schist and phyllite containing abundant pods and stringers of white quartz. Green to 
silvery gray phyllite containing abundant stringers of quartz (fig. 2), which crops out at scattered localities in the southwest corner of the Cupsuptic quadrangle, is assigned to the upper part of the Aziscohos Formation of Green (1964) which is herein adopted. The lower carbonaceous part of the Aziscohos Formation is not exposed in the mapped area.

The phyllite is composed of quartz, muscovite, albite, chlorite, magnetite, tourmaline, and zircon; its surface weathers to a soft, chalky white rind that is locally studded with euhedral to subhedral magnetite porphyroblasts as much as $2 \mathrm{~mm}$ (millimeters) on an edge. Thin, lightgray to greenish-gray metasiltstone beds that are 1 to 5 inches thick and have essentially the same composition as the phyllite make up less than 5 percent of this part of the Aziscohos Formation.

The upper noncarbonaceous part of the Aziscohos Formation grades into the Albee Formation through a zone of intermixed lithologies ranging in thickness from 200 to 500 feet. The green to silvery gray phyllite is the same in both formations; in the gradational zone, however, the number of quartzite and feldspathic quartzite beds character-

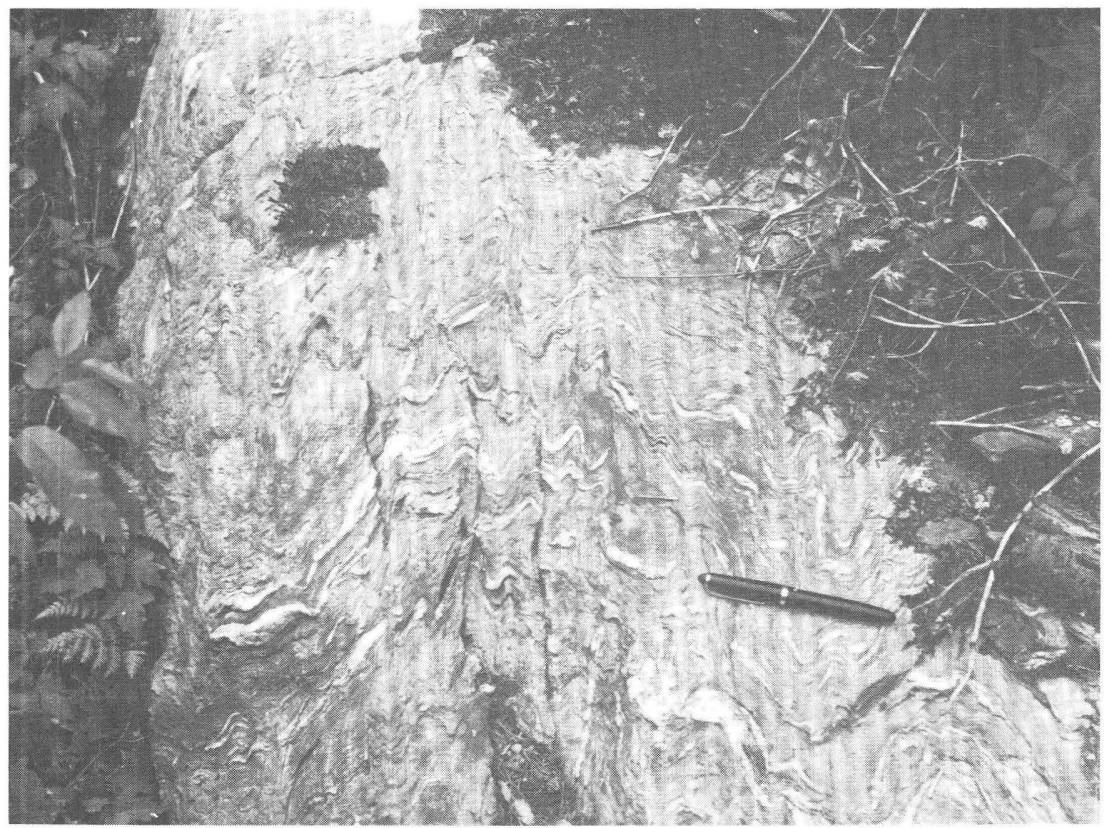

FIGURE 2.-Green to silvery gray phyllite, containing abundant stringers of white quartz, characteristic of the upper part of the Aziscohos Formation about 1 mile north of the southwest corner of the Cupsuptic quadrangle. Quartz stringers are parallel to foliation and are folded about north-trending slip cleavage. Note hinge of early isoclinal fold outlined by quartz stringer at lower left-hand corner of outerop. 
istic of the Albee increases and the number of quartz stringers typical of the Aziscohos decreases. This intermixing strongly suggests that the noncarbonaceous Aziscohos is a facies of the Albee as originally proposed by Green (1964). The contact was arbitrarily drawn where the arenaceous rocks make up 10 percent or more of an exposure. This may not correspond exactly to the Aziscohos-Albee boundary drawn by Green (1964, p. 13) on the "first appearance" of quartzite, but his criterion was not sufficient to separate the formations in the Cupsuptic area.

Green (1964, p. 16) estimated the thickness of the Aziscohos in the Errol quadrangle (fig. 1) to be 7,000 feet, but most of this is the lower carbonaceous part of the formation. Assuming no repetition due to folding and an average dip of $70^{\circ}$, the maximum thickness of the upper noncarbonbonaceous part of the Aziscohos is about 4,000 feet in the Cupsuptic quadrangle. These rocks are intensely folded, however, and an estimate of 2,000 feet is probably more nearly correct.

No fossils have been found in the Aziscohos Formation, but it is gradationally below the Albee Formation which, in turn, underlies the Middle Ordovician Dixville Formation so the Aziscohos can be no younger than Middle Ordovician. Green (1964, p. 65) considered the Aziscohos to be Late Cambrian to Early Ordovician from lithologic correlation with the Stowe Formation and possibly with the Ottauquechee Formation in eastern Vermont. The upper part of the Aziscohos is remarkably similar to the noncarbonaceous part of the Stowe and both underlie similar distinctive rocks (Albee and Moretown Formations, respectively) so their correlation seems reasonably certain. Cady (1968) considered the Stowe to be Early Ordovician and Zen (1967) correlated the upper part of the Stowe and the overlying Moretown Formation with the $\mathrm{B}$ and $\mathrm{C}$ members of the Poultney Slate which contains Early and Middle Ordovician graptolites. However, because the Aziscohos Formation underlies the Albee Formation, which is of Early and Middle Ordovician age, the Aziscohos is considered to be of Early Ordovician age only.

\section{ALBEE FORMATION}

The name Albee Formation was given by Billings (1934) to green, greenish-gray, and black slate interbedded with quartzite exposed on Albee Hill near Littleton, N.H., 65 miles southwest of the Cupsuptic quadrangle. The distinctive rocks of the Albee have been mapped continuously from the type area, through various metamorphic zones in easternmost Vermont (Doll and others, 1961) and northern New Hampshire (Billings, 1956), to the southern part of the Cupsuptic quadrangle. For this reason the Albee forms the most reliable link 
between the stratigraphy of northern New Hampshire and westcentral Maine.

In the Cupsuptic-Arnold Pond area, the Albee Formation is composed of green, gray, red, and black slate and phyllite interbedded with quartzite and feldspathic quartzite in variable proportions. It is herein divided into three members using the relative abundance of arenaceous rocks and the dominant color of the slate and phyllite as distinguishing criteria. These members are the Kennebago, Portage Brook, and Deer Mountain Members. The members have local stratigraphic significance, but those separated on the basis of red versus green slate cannot be recognized in the higher grades of metamorphism in New Hampshire where the pelitic rocks are gray or silver-gray schists. Furthermore, the Deer Mountain Member appears to pinch out across strike in the Cupsuptic quadrangle, and the Kennebago Member may become indistinguishable or inseparable from the Portage Brook Member along strike.

The maximum thickness of the Albee Formation is about 10,500 feet; the Portage Brook Member accounts for about 6,000 feet and the Kennebago Member accounts for as much as 4,500 feet. The Deer Mountain Member is about 2,500 feet thick in its type area but wedges out completely to the north and northwest.

No fossils have been found in the Albee Formation, but it must be Middle Ordovician or older because it underlies black slate of the Dixville Formation which contains Middle Ordovician graptolites in the southeastern part of the Cupsuptic quadrangle (pl. 1, fossil loc. 0-1). Billings (1956) concluded that the Albee was Middle Ordovician or older from lithologic correlations with the Moretown Formation in eastern Vermont. The Moretown is apparently equivalent to the Beauceville Formation that contains late Middle Ordovician graptolites at Magog, Quebec (Berry, 1962). Zen (1967, p. 55) has recently correlated the Moretown and part of the underlying Stowe Formation with the B and C members of the Poultney Slate (Theokritoff, 1964) in the northern Taconic Mountains of Vermont. This part of the Poultney contains red, green, and black slate interbedded with quartzite and has been dated as late Early Ordovician to early Middle Ordovician by its graptolite assemblages (Berry, 1959). The B and C members of the Poultney bear striking lithologic similarity to the noncarbonaceous part of the Aziscohos Formation and to the Albee Formation, and both the Poultney and the Albee underlie black slate units containing fossils of equivalent age. Therefore, a tentative correlation between the Albee and the Poultney seems justified, and the Albee is concluded to range in age from Early to Middle Ordovician. This correlation extends the age of the Albee from Middle Ordovician into the Early Ordovician. 
PORTAGE BROOK MEMBER

Green phyllite and slate containing beds of finely laminated, gray to light green quartzite and feldspathic quartzite that form 10 to 50 percent of an exposure are herein assigned to the Portage Brook Member of the Albee Formation. Exposures in the middle reaches of Portage Brook and on the ridge between Portage Brook and Lincoln Pond are designated the type area of this member, and the name is taken from Portage Brook. Other good exposures are found on the lower east slope of Deer Mountain and on the east-trending ridge west of Deer Mountain.

The Portage Brook Member is the most widespread member in the formation and appears to represent the entire formation in the Southwestern part of the Cupsuptic quadrangle. It is equivalent to the undivided Albee Formation mapped by Green $(1964,1968)$ in the Errol and Second Lake quadrangles. Furthermore, the other members of the Albee appear to be lithofacies of the Portage Brook Member that were formed by changes in environmental conditions during deposition.

The Portage Brook Member is gradational into the noncarbonaceous upper part of the Aziscohos Formation in the southwestern part of the Cupsuptic quadrangle. In the central part of the quadrangle, the Portage Brook Member is underlain by red slate and interbedded quartzite assigned to the Kennebago Member of the Albee. The contact between the Kennebago Member and the Portage Brook Member is exposed on the low hills about three-fourths of a mile south of the upper reaches of the South Branch of Black Cat Brook (pl. 1) and on the southwest slope of the 2,040-foot hill 1.2 miles southwest of Riverside Camp (pl. 1), where it is conformable and sharply gradational through a zone of mixed red, green, and purplish-gray slate about 3 feet thick. In a few areas, discontinuous patches of black slate as much as 75 feet thick separate the Portage Brook Member from the underlying Kennebago Member.

\section{Green Phyllite and Slate}

Dark-green to light-yellowish-green phyllite and slate that weathers chalky white or light gray make up 40 to 90 percent of the Portage Brook Member; the remainder is composed of arenaceous rocks described below. Foliation surfaces are commonly dull in the slate but have a silvery sheen in the phyllite because of an increase in the size of muscovite and chlorite. The phyllite and slate are commonly dragged 
into the interbedded arenaceous rocks by crosscutting cleavage. In the more fissile varieties, especially in areas of pronounced slip cleavage, the slate at the surface of the outcrop flakes off to form a chip rubble (fig. 3) leaving the arenaceous beds in relief.

The phyllite and slate are composed primarily of quartz, albite, muscovite, chlorite, and magnetite and minor amounts of tourmaline, zircon, ilmenite, and rutile. Representative modes are given in table 1 (Samples 1, 2). Muscovite is extremely fine grained and has distinct grain boundaries, whereas chlorite occurs as somewhat larger scaly masses that have poorly defined crystal boundaries. Quartz and untwinned albite generally form angular to subangular grains about $50 \mu$ (microns) in maximum diameter. Magnetite octahedra, as much as $0.5 \mathrm{~mm}$ on an edge, are common in the phyllite and stud the weathered surface. Tourmaline, pleochroic in blue green to straw yellow, and rultile form euhedral crystals about $20 \mu$ long; zircon occurs as either euhedral or rounded grains about $50 \mu$ in length.

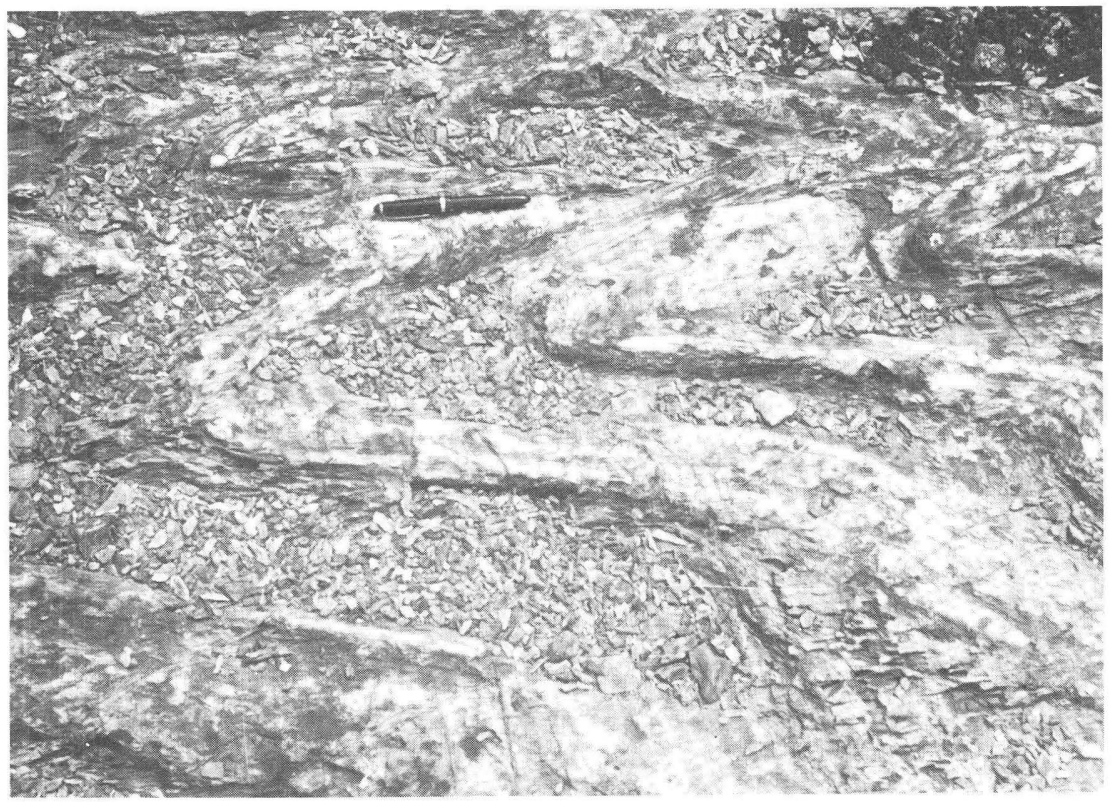

FIGURE 3.-Typical chip-rubble weathering of green phyllite and slate interlayered with contorted quartzite beds in the Portage Brook Member of the Albee Formation, 1.5 miles N. $65^{\circ} \mathrm{W}$. of Riverside Camp. 
TABLE 1.-Representative estimated modes of the

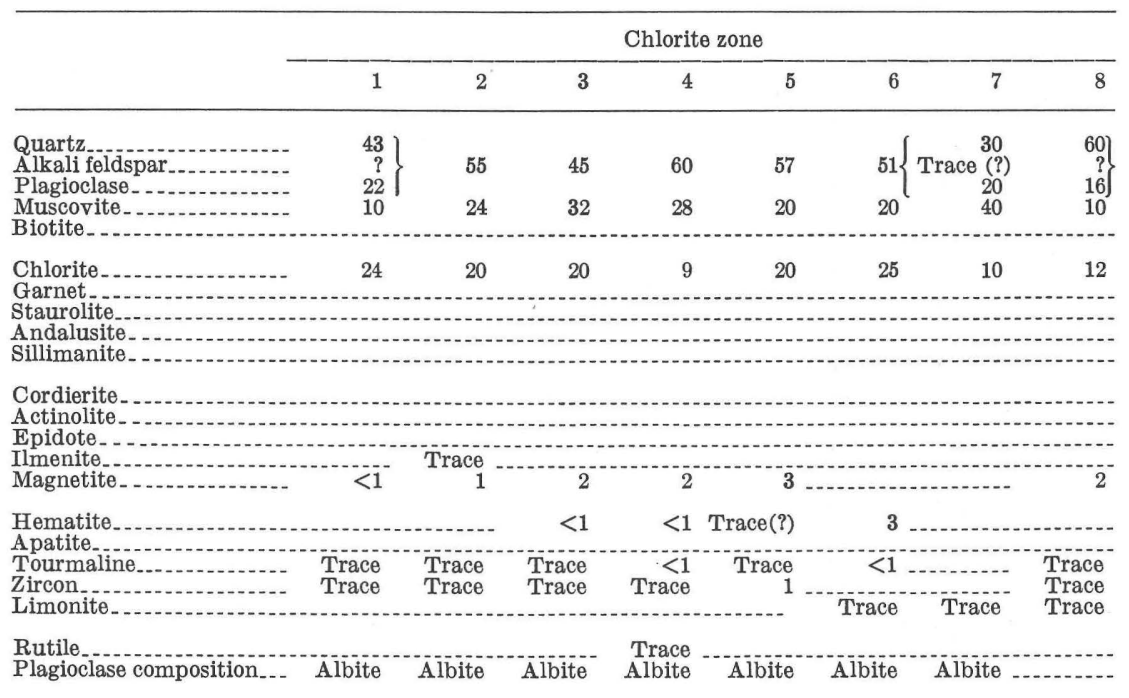

1. Green phyllite of Portage Brook Member adjacent to pinstripe quartzite; 1.4 miles (bearing $274^{\circ}$ ) from camp on west side of Lincoln Pond.

2. Green phyllite of Portage Brook Member; 1.5 miles west of summit of Deer Mountain.

3. Red slate of Kennebago Member; on 2,240-foot topographic knob 0.95 mile (bearing $17^{\circ}$ ) from camp on west shore of Lincoln Pond.

4. Purplish-gray quartzite of Kennebago Member; 1.1 miles (bearing $303^{\circ}$ ) from 1,531-foot bench mark at Big Falls on the Cupsuptic River.

5. Green phyllite of Deer Mountain Member; on 2,385-foot summit of Daddys Ridge.

6. Purplish-gray phyllite of the Deer Mountain Member; at 2,160 feet altitude, 2.1 miles (bearing $261^{\circ}$ ) from 1,578-foot bench mark on South Brook.

7. Black phyllite of Deer Mountain Member; at 1,560 feet altitude in first south-trending branch of Cold Brook 3,000 feet (bearing $279^{\circ}$ ) from intersection of Route 16 and Cold Brook.

8. Feldspathic quartzite in Portage Brook Member; on east shore of Lincoln Pond, 3,300 feet (bearing $130^{\circ}$ ) from camp on west side of Lincoln Pond.

9. Light gray, slightly maculose phyllite of Kennebago Member; at 1,920 feet altitude south of 2,940-foot summit of Burnt Mountain.

\section{Feldspathic Quartzite}

The feldspathic quartzite beds are characterized by dark-green, paper-thin micaceous laminae separated by lighter gray or green, equigranular quartz-feldspar-rich bands that range in thickness from a few millimeters to about $3 \mathrm{~cm}$ (centimeters). The micaceous laminae, which weather more rapidly than the equigranular layers, give the arenaceous beds a diagnostic striped appearance referred to by Cady (1956) as the "pinstripe" texture in similar rocks in the Moretown Formation. The micaceous laminae are thought to represent primary layering because they parallel bedding contacts even at fold noses (fig. 4 ) and because they are commonly more closely spaced near the top of a bed indicating a gradational change from the arenaceous rocks to the pelitic rocks. Distinct grading of grain size in the quartzfeldspar-rich bands, however, is not a common feature in the feldspathic quartzite. 
Albee Formation in the Cupsuptic quadrangle, Maine

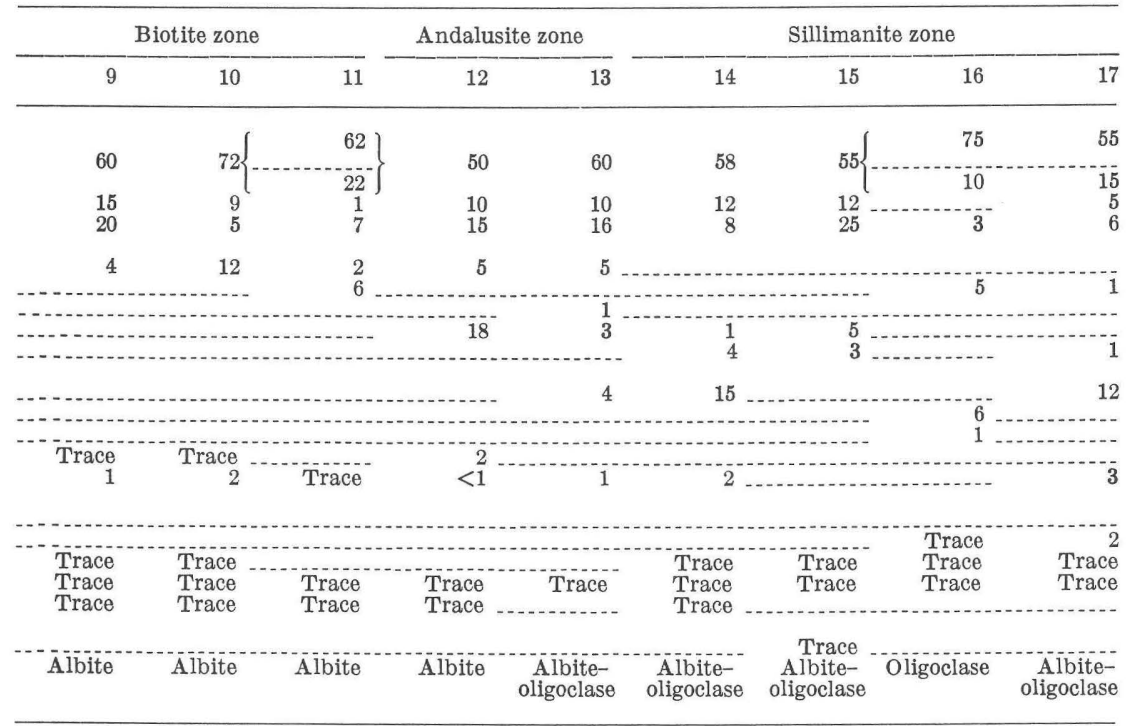

10. Green, maculose phyllite of Portage Brook Member; at 1,540 feet altitude in Lost Brook, 900 feet upstream from 1,531-foot bench mark at Big Falls on the Cupsuptic River.

11. Feldspathic quartzite in Portage Brook Member; same location as sample 10.

12. Gray, maculose hornfels of Kennebago Member; 1,800 feet (bearing $253^{\circ}$ ) from 2,660-foot summit of Cupsuptic Mountain.

13. Gray, maculose hornfels of Portage Brook Member; at 2,180 feet altitude, 200 feet north of 2,217-foot summit of Big Buck Mountain.

14. Dark gray, muscovite-spangled hornfels of Portage Brook Member; at 2,620 feet altitude, 1,200 feet east of 2,940-foot summit of Burnt Mountain.

15. Dark gray, fine-grained, equigranular hornfels of Portage Brook Member; at 2,160 feet altitude, 500 feet north of 2,217-foot summit of Big Buck Mountain.

16. Gray-green, fine-grained, calc-silicate rock in Portage Brook Member; at 2,415 feet altitude, 1,200 feet (bearing $315^{\circ}$ ) from 2,660-foot summit of Cupsuptic Mountain.

17. Dark gray hornfels of Kennebago Member containing large cordierite porphyroblasts; at 2,450 feet altitude, 900 feet west of 2,660-foot summit of Cupsuptic Mountain.

The equigranular layers (table 1, samples 8, 11) are composed primarily of quartz, untwinned albite, muscovite, and chlorite. Micaceous minerals are most abundant in the dark pinstripe laminae (fig. 4) and are associated with concentrations of magnetic, tourmaline, zircon, and, less commonly, rutile. Some feldspathic quartzite beds are calcareous or they contain calcareous pods that weather to a brown punky rind. The equigranular layers in such beds contain calcite in addition to the minerals listed above. The feldspathic quartzite beds commonly part parallel to the micaceous laminae.

In the higher grades of contact metamorphism, biotite forms in the granular layers; biotite, cordierite, andalusite, or sillimanite may be present in the pinstripe laminae, and the calcareous parts of the feldspathic quartzite (table 1, sample 16) are calc-silicate beds or pods composed of quartz, plagioclase, garnet, actinolite, biotite, and apatite. 


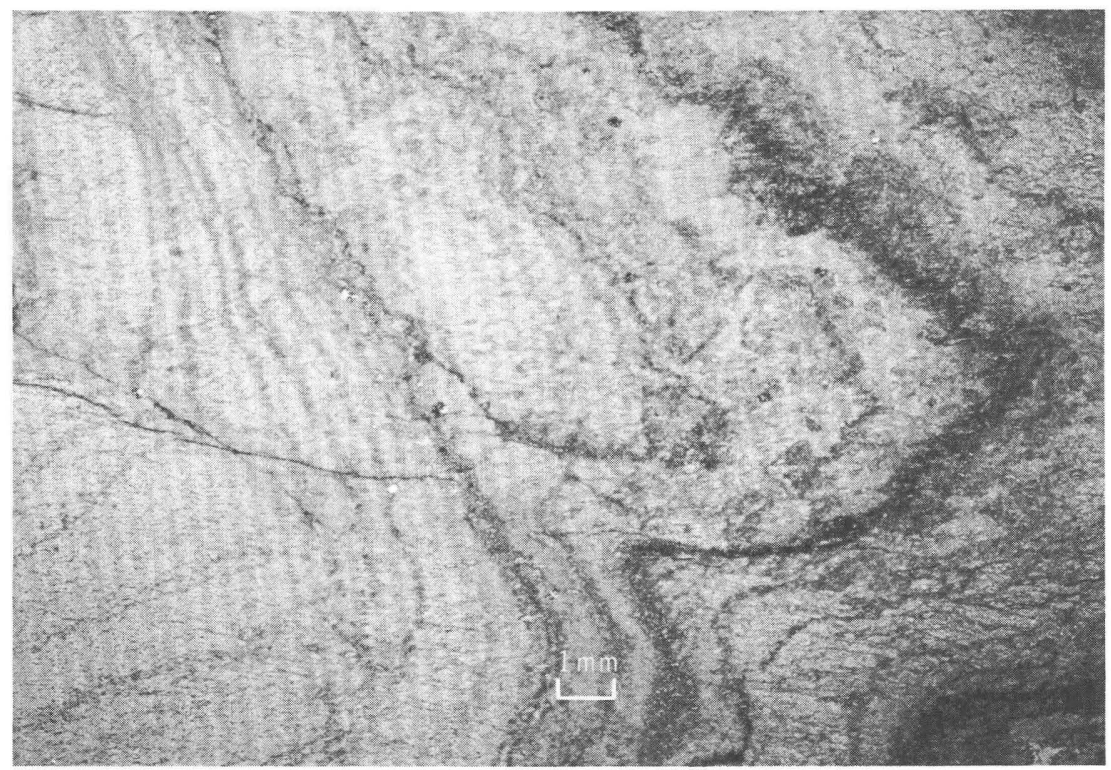

FIguRE 4 (above and right).-Dark-gray paper-thin micaceous laminations (pinstripe structure) in light gray feldspathic quartzite of the Portage Brook Member of the Albee Formation. Right: Pinstripe laminae in outcrop on east slope of Deer Mountain looking northeast; pencil is about 5 inches long. Above: Photomicrograph of pinstripe laminae (dark). Dark layers are rich in chlorite, muscovite, zircon, tourmaline, and magnetite; light layers are rich in quartz and feldspar. Plane-polarized light.

\section{QUARTZITE}

Gray, greenish-gray, and green hard vitreous-weathering quartzite forms beds in the phyllite and slate that range in thickness from a few inches to as much as 2 feet; the average thickness is about 8 inches. Graded bedding is more common in the quartzite than in the feldspathic quartzite, and the pinstripe laminae are generally less distinct, discontinuous, and are commonly absent from the base of the quartzite beds. Quartzite beds appear to be randomly associated with the feldspathic quartzite beds in the Portage Brook Member.

The quartzite is composed of the same minerals-predominantly quartz, albite, muscovite, and chlorite-as the feldspathic quartzite, and because gradational types exist, the distinction between the two is made arbitrarily on the quartz content. Quartzite contains 70 to 90 percent quartz and feldspathic quartzite contains 50 to 70 percent quartz. Quartz is subrounded to subangular and is about $0.5 \mathrm{~mm}$ in maximum diameter. Albite grains are subangular, commonly elongate, and are smaller than the quartz grains. Muscovite and chlorite are pres- 


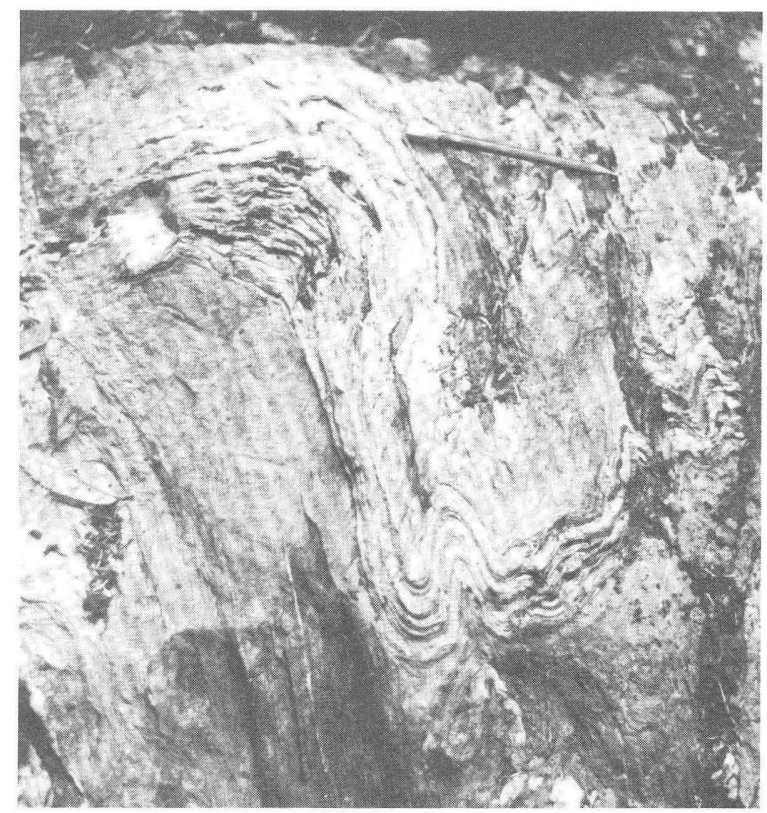

ent in minor amounts in the arenaceous layers and are abundant in the pinstripe laminae, which also contain magnetite, zircon, tourmaline, and limonite.

KEN NEBAGO MEMBER

The Kennebago Member of the Albee Formation is herein adopted for red, maroon, purplish-gray, and minor green slate that contains 10 to 50 percent feldspathic quartzite and quartzite and sparse discontinuous lenses of black slate and greenstone. This member underlies the Portage Brook Member in the central part of the Cupsuptic quadrangle. The nearly continuous exposures along the banks of the Kennebago River that extend about half a mile downstream from the dam at the outlet of Kennebago Lake are designated as the type locality and the name is taken from the abandoned logging settlement of Kennebago. A planetable map of the rocks at the type locality is shown on plate 2.

The Kennebago Member crops out in a narrow band that trends southwest from the type locality and curves to the west around the Cupsuptic pluton; west of the pluton, the Kennebago Member forms two narrow bands of variable trend. Good exposures are found on the low northwest-trending ridge west of Lost Brook and on the hills south of the headwaters of the South Branch of Black Cat Brook (pl. 1).

The lower contact of the Kennebago Member is not exposed. The upper contact of the Kennebago Member with the Portage Brook Mem- 
ber is conformable and sharply gradational; locally, this upper contact is marked by lenses of black slate 0 to 75 feet thick. The contact between the black slate and the purplish-gray slate of the Kennebago Member is conformable and gradational over a zone about 3 feet thick. Similar contact relationships are present between the black slate and the overlying green slate of the Portage Brook Member.

Red slate has not been reported previously in the Albee, but this may be due to the higher metamorphic grade in the areas of New Hampshire where the Albee is observed. Apparently an analogous situation exists between the red slate, "Caldwell Facies," of the Mansonville Formation (Cooke, 1937, p. 22) in Quebec and the higher grade equivalent green slate and phyllite of the Stowe Formation on strike with the Mansonville in northern Vermont (Cady, 1960; Cady and others, 1963).

\section{Red Slate}

The red slate is composed primarily of quartz, muscovite, chlorite, albite, hematite, zircon, tourmaline, rutile, and locally magnetite, in the proportions given for sample 3 in table 1 . All the minerals are microscopic except magnetite and, less commonly, muscovite which can be seen with a hand lens. Quartz and untwined albite are angular to subangular and are about $50 \mu$ in maximum diameter. Muscovite forms distinct flakes, whereas chlorite is present as low birefringent masses that lack distinct grain boundaries and have an anomalous blue interference color. Hematite plates are blood red, are about $20 \mu$ in size, and are commonly hexagonal in outline. Tourmaline forms single crystals as much as $0.1 \mathrm{~mm}$ long that are strongly pleochoric from blue green to colorless. Rutile is commonly present as euhedral twinned crystals or as acicular aggregates less than $50 \mu$ in length.

In the contact-metamorphic aureoles the red slate of the Kennebago Member is a dark-gray maculose or equigranular hornfels that is distinguishable from the contact-metamorphosed green slate of the Portage Brook Member only by its greater magnetite content. The red slate hornfels contains cordierite, biotite, andalusite or sillimanite (or both), quartz, muscovite, albite, ilmenite, magnetite, and tourmaline. Hematite is not present in the rocks that contain biotite.

\section{Feldspathic Quartzite}

Dark-green or greenish-tan, chalky-weathering, feldspathic quartzite beds containing maroon or purplish-gray, paper-thin, micaceous laminae are interbedded in variable proportions with the red slate of the Kennebago Member. The feldspathic quartzite makes up about 25 percent of the member at the type locality but may account for as 
much as 50 percent of it west of the Cupsuptic pluton (pl. 1). The beds range in thickness from 1 inch to about 12 inches and are locally graded.

Subangular to subrounded quartz and untwinned albite, present in variable but major proportions together with lesser amounts of muscovite and chlorite, form the arenaceous layers of the feldspathic quartzite. Muscovite, chlorite, hematite, rutile, and tourmaline are most abundant in the micaceous laminae.

\section{QUARTZITE}

At least two discontinuous and highly folded beds of vitreous, whiteweathering, greenish-gray quartzite (see pl. 2) are exposed in the red slate at the type locality of the Kennebago Member. The beds range in thickness from about 8 to 24 inches and have been tectonically thickened and thinned in very tight minor folds. These beds lack the characteristic micaceous laminae found in the feldspathic quartzite.

The quartzite is composed predominantly of subangular to subrounded, medium- to coarse-grained quartz and contains subordinate amounts of albite, muscovite, and chlorite.

\section{Black Slate and Greenstone}

Discontinuous lenses of black slate, as much as 75 feet thick, are found along the contact between the red slate of the Kennebago Member and the green slate of the Portage Brook Member. A lens of greenstone about 20 feet thick occurs in the red slate immediately below the black slate lens near the type locality of the Kennebago Member.

Because finely divided carbonaceous material of unknown composition renders thin sections of the black slate nearly opaque, the major constituents quartz, muscovite, chlorite, and albite were determined by $\mathrm{X}$-ray diffraction methods.

\section{DEER MOUNTAIN MEMBER}

The name Deer Mountain Member is adopted herein for green slate and phyllite that contain thin stringers of quartz and less than 10 percent feldspathic quartzite. It includes lenticular units of black phyllite at the base, purplish-gray and green phyllite near the top, and minor greenstone. This member overlies the Portage Brook Member of the Albee Formation in the southern part of the Cupsuptic quadrangle. Although a type section cannot be established owing to scattered exposures, a type area is designated as the north slope and northeast-trending ridge of Deer Mountain ( $p l .1$ ), for which the member is named. 
The lower contact of the Deer Mountain Member is defined over most of the area by the sharp and conformable change upward from green slate and phyllite of the Portage Brook Member to rustyweathering, black phyllite-the lowest lithologic unit in the Deer Mountain Member. Where the black phyllite is absent on the north and northeast side of the Deer Mountain syncline (pl. 1), green slate and phyllite of the Portage Brook Member are in contact with green slate and phyllite of the Deer Mountain Member and no clear-cut boundary exists between them. In such areas the contact is arbitrarily placed so that green slate and phyllite containing 10 percent or more of arenaceous rocks are assigned to the Portage Brook Member and green slate and phyllite that have less than 10 percent of arenaceous rocks are assigned to the Deer Mountain Member. These contact relations can be seen in large pavement exposures on the west side of the road to Big Falls about 0.4 mile south of Fox Pond (pl. 1).

The upper contact of the Deer Mountain Member is exposed along the west slope of Cloutman Ridge (pl. 1). Here, layers of green phyllite 10 to 50 feet thick alternate with layers of greenstone of similar thickness through a zone about 300 feet thick. The contacts between the greenstone and green phyllite layers are sharp. No unconformity could be seen between the greenstone and green phyllite, but bedding is rare in both lithologies. It is unlikely that the green phyllite is folded into the greenstone because the layers of rock continue along the length of Cloutman Ridge without any sharp variation in trend around minor fold noses. The zone of alternating green phyllite and greenstone is interpreted to be a primary mixing of mud and volcanic rocks.

\section{Black Phyllite}

Dull black to silvery black, rusty weathering, sulfidic, carbonaceous phyllite that contains less than 10 percent of thin feldspathic quartzite beds forms the lowest lenticular unit of the Deer Mountain Member. The arenaceous beds, which are commonly less than 2 inches thick, are generally not graded and do not contain the distinct micaceous pinstripe laminations found in the Portage Brook Member.

The black phyllite contains quartz, muscovite, chlorite, albite, pyrite, and minor amounts of zircon and tourmaline. Finely divided particles of carbonaceous material of unknown composition are also present. Quartz, albite, muscovite, chlorite, pyrite, and carbonaceous material make up the feldspathic quartzite.

\section{Green Slate and Phyllite and Greenstone}

Green slate and phyllite, like those of the Portage Brook Member, overlie the black phyllite described above and overlie the Portage 
Brook Member where the black phyllite is missing. The order of superposition can be determined by graded beds in the Portage Brook Member exposed beside the road to Big Falls 0.4 mile south of Fox Pond (pl. 1). The green slate and phyllite unit of the Deer Mountain Member is distinguished from that of the Portage Brook Member by the scarcity of arenaceous beds and by the greater abundance of quartz stringers, about a quarter of an inch thick, in the Deer Mountain Member. Green phyllite of the Deer Mountain Member is similar to that in the upper part of the Aziscohos Formation but it contains fewer stringers of quartz, and the Deer Mountain Member also contains scattered lenses of greenstone and purplish-gray phyllite that are not found in the Aziscohos. Quartz, muscovite, chlorite, albite, magnetite, zircon, tourmaline, and, locally, rutile make up the green slate and phyllite.

Discontinuous layers of greenstone, less than 50 feet thick, are scattered in the green phyllite. Low hogback ridges of greenstone (not shown on pl. 1), less than 20 feet thick, are commonly found at the green phyllite-black phyllite contact. The greenstone is composed of albite, actinolite, calcite, chlorite, epidote, sphene, and minor amounts of magnetite and pyrite.

\section{Purplish-Gray Phyllite}

Purplish-gray phyllite interlayered with green phyllite forms a lenticular map unit near the top of the Deer Mountain Member. These rocks are well exposed on the east slope of the northeast-trending ridge north of Deer Mountain and the east-flowing tributary of the Kennebago River, 1,000 feet north of the abandoned settlement of Realty (pl. 1). The upper and lower contacts of this lenticular unit are drawn to enclose the known outcrops of purplish-gray phyllite. The proportion of green phyllite interlayered with the purplish-gray phyllite increases toward the contacts.

The purplish-gray phyllite has a mineral composition similar to that of the green phyllite of the Deer Mountain and Portage Rock Members with the addition of minor amounts of hematite. Green phyllite is interlayered with the purplish-gray phyllite in variable proportions but, in general, it makes up 15 to 30 percent of an exposure.

The purplish-gray phyllite can be distinguished from the red slate of the Kennebago Member primarily by the relative scarcity of arenaceous beds, which make up less than 5 percent of an exposure of this unit; by its less vivid color; and by its association with green phyllite that lacks abundant arenaceous rocks typical of the Portage Brook Member. 


\section{DIXVILLE FORMATION}

The name Dixville Formation was proposed by Green (1964) for black phyllite and schist, quartzite, and amphibolite that overlie the Albee Formation on the west side of the Errol quadrangle (fig. 1). These rocks extend westward into the Iixville quadrangle, where they were mapped by Hatch (1963), and northward into the Second Lake quadrangle (fig. 1), where they were mapped to the Cupsuptic border by Green (1968). In the type area, Green subdivided the formation into the Dixie Brook Member, consisting mainly of black phyllite and schist; the Clear Stream Amphibolite Member; and the Rice Mountain Member, made up of black schist interbedded with quartzose and spessartitic granofels. These major lithologies are present in the Cupsuptic quadrangle, but the mafic volcanic rocks (Clear Stream Amphibolite Member), essential to Green's origin subdivision, are neither continuous nor are they in one stratigraphic position here; therefore, the original member names are not used herein.

In the area of this report, the Dixville Formation has been divided into a lower unnamed black slate member that contains mappable lenses of greenstone, quartzite, and calcareous graywacke, and an upper member, named the Magalloway Member by Green (1968), composed primarily of feldspathic graywacke that contains mappable layers of greenstone. The black slate member of this report includes the unnamed greenstone and slate unit and the unnamed black slate unit of Harwood and Berry (1967) and probably includes all of the Dixie Brook Member of Green (1964) and all, or part, of his Clear Stream and Rice Mountain Members. The Magalloway Member is continuous with rocks mapped as the Arnold River Formation by Marleau (1957) in the Woburn area, Quebec (fig. 1).

The black slate member in the northern half of the Cupsuptic quadrangle is continuous with the Dixie Brook Member of the Dixville mapped by Green (1968) in Second Lake quadrangle. Black slate, greenstone, and graywacke in the Green Top syncline (pl. 1) and in the southeastern part of the Cupsuptic quadrangle are assigned to the Dixville Formation because of lithologic similarity and stratigraphic position above the Albee Formation. Greenstone, graywacke, and slate in the northwestern part of the Arnold Pond quadrangle, considered Devonian by Green (1968) and Marleau (1968), are included in the Dixville by Harwood (1969a) because of (1) their lithologic similarity to the main belt of Dixville, (2) their stratigraphic position below rocks of Silurian and Devonian age, and (3) because they are intruded by bodies of serpentinite that to date have been found only in rocks of Middle Ordovician or older age (Chidester, 1962). 
The lower contact of the black slate member with the Albee Formation was not observed because of glacial cover, but it was located within 10 feet in several places near the northern end of the Black Cat anticline and of the Green Top syncline (pl. 1). In these areas, graded beds in both formations indicate that the black slate member overlies the Albee. The contact between the black slate member and the overlying Magalloway Member is gradational and conformable where it was observed along the northeast-trending ridge southeast of the First East Branch of the Magalloway River in the north-central part of the Cupsuptic quadrangle. The lower 10 feet of the Magalloway Member consists of alternating beds of pyritic olive-green metasiltstone and metagraywacke, 4 to 8 inches thick, that are commonly graded, indicating that the Magalloway Member overlies the black slate member. This stratigraphic relationship strengthens the conclusion that the black slate member overlies the Albee Formation, because the Megalloway does not appear between the black slate member and the Albee.

The thickness of the black slate member may be as much as 12,000 feet, assuming an essentially homoclinal sequence in the southeastern part of the Cupsuptic quadrangle. The Magalloway Member is about 4,500 feet thick on the basis of measurements from cross sections (pl. 1).

The age of the black slate member of the Dixville at fossil locality $0-1$ in the southeastern part of the Cupsuptic quadrangle has been established as late Middle Ordovician by an assemblage of graptolites (Harwood and Berry, 1967) indicative of the Climacograptus bicornis zone (Berry, 1960). Fragments of shelly fossils from the lens of calcareous graywacke at Kamankeag Brook (pl. 1, fossil loc. 0-2) were studied by R. B. Neuman, who concluded that they were compatible with the Middle Ordovician age established by the graptolites. The black slate member at the northern end of the Black Cat anticline contains fragments of Protospongia sp. at fossil locality 0-3 southeast of Bottle Mountain (pl. 1), which were studied by R. M. Finks. Although Protospongia ranges in age from Cambrian through Ordovician and thus does not unequivocally date these rocks, they are assigned a Middle Ordovician age because they correlate lithologically and stratigraphically with the graptolite-bearing slate at fossil locality $0-1$. The Magalloway Member is also assigned a Middle Ordovician age by correlation with similar rocks, which contain brachiopods of that age, found near The Forks, Me., by E. V. Post. (See Harwood and Berry (1967) and Neuman (1968, p. 40).)

\section{BLAGK SLATE MEMBER}

Rusty-weathering, sulfidic, carbonaceous black slate and phyllite locally interbedded with feldspathic quartzite and felsic tuff makeup 
more than 80 percent of the lower part of the Dixville Formation. Black slate, well exposed on the low hills north of Kamankeag Pond (pl. 1), is the most common rock in the southeastern part of the Cupsuptic quadrangle. Silver-black phyllite, well exposed in the Big Canyon of the Cupsuptic River and on the low hills east of Parmachenee Lake (pl. 1), forms the bulk of the member north of the Albee Formation. The black slate and phyllite apparently are not as resistant to erosion as rocks of the Albee Formation, and exposures of this member are generally scarce.

The pelitic rocks of the black slate member vary from soft, highly fissile, dull, sooty-black slate to intensely crenulated and sheared silverblack phyllite. All varieties are rusty weathering and contain disseminated cubes and pod-shaped aggregates of pyrite in the chlorite zone and smears of pyrite or pyrrhotite in the higher grade, contact-metamorphic zones. The black slate near fossil locality $0-1$ is hard, siliceous, and contains gray chert laminae about $3 \mathrm{~mm}$ thick.

Dark-gray, fine-grained, sulfidic, feldspathic quartzite beds 3 to 6 inches thick are scattered in the black slate member. Generally the arenaceous beds make up less than 5 percent of the member, except on the slopes of Ephraim Ridge where they account for as much as 30 percent of an exposure. Here, feldspathic quartzite beds that are commonly graded and about 2 inches thick alternate with layers of black slate 6 to 10 inches thick to form a cyclically bedded rock. Prominent joints oriented parallel to bedding produce a slabby talus from this cyclically bedded part of the black slate member.

The feldspathic quartzite is composed of quartz, albite, muscovite, chlorite, and pyrite; biotite is locally abundant where the rock is contact metamorphosed.

North of the Albee Formation the black slate member contains less than 5 percent of light-gray, chalky-weathering, very fine grained felsic tuff or metasiltstone beds and lenses that are generally less than 2 inches thick. The felsic tuff has essentially the same composition as the feldspathic quartzite but contains more albite than quartz.

The major minerals of the black slate member, as determined by $\mathrm{X}$-ray diffraction, are quartz, muscovite, chlorite, albite, and pyrite. Zircon, tourmaline, and, less commonly, zoisite (?) are present in minor amounts. Where the black slate member is contact metamorphosed, it forms a maculose andalusite-bearing hornfels or, adjacent to the igneous rock, an equigranular sillimanite-cordierite-bearing hornfels.

\section{LENTIGULAR UNITS IN THE BLAGK SLATE MEMBER}

Many greenstone lenses of variable size, thickness, and stratigraphic position are scattered throughout the black slate member. In addition, one lens of calcareous lithic graywacke and conglomerate was found in 
the black slate member west of Kamankeag Pond (pl. 1), and several scattered patches of quartzite, probably on one stratigraphic horizon, were found on the limbs and nose of the Black Cat anticline.

\section{Greenstone}

Dark-green massive to crudely foliated greenstone that weathers light gray to rusty brown occurs as lenses 200 to 7,500 feet thick at widely separated stratigraphic positions within the black slate member. The largest lens of greenstone interfingers with black slate near Kamankeag Brook (pl. 1) and extends southward into the Oquossoc quadrangle (fig. 1). All the greenstone lenses are rather resistant and exposures are numerous.

Although the greenstone is most commonly massive and intensely fractured, it contains faintly preserved pillow structures, primary compositional layering, and thin agglomerate layers in scattered localities, indicating that the greenstone originated as lava flows and, to a lesser degree, as accumulations of coarse volcanic ejecta.

Albite or sodic oligoclase, actinolite, chlorite, calcite, epidote, and sphene are the major minerals. Actinolite and plagioclase are commonly intergrown in an ophitic texture. Ilmenite, magnetite, and pyrite are present in minor amounts. Locally, the greenstone contains lightgreen epidote-rich layers or pods a few inches thick which alternate with dark-green actinolite-chlorite-rich layers 2 to 12 inches thick.

\section{Galcareous Lithic Graywacke}

Massive to well-bedded calcareous lithic graywacke forms a mappable lens in the black slate member in the southeastern part of the Cupsuptic quadrangle. The lens is about 200 feet thick and extends northward from Kamankeag Brook at least as far as the low hills near fossil locality 0-1 (pl. 1). The calcareous lithic graywacke is massive and coarsely conglomeratic where it is in sharp but conformable contact with the underlying black slate. Near the top of the lens, graywacke beds 2 to 12 inches thick are interlayered with black slate beds 2 to 6 inches thick. Crossbedding, channel structures, and wispy lenticles of black slate are locally abundant. Conglomerate layers as much as 2 feet thick occur at and near the base of the lens and contain subrounded clasts of black slate, chert, granular white quartz, greenstone, and green phyllite as much as 3 inches in diameter, set in a matrix of fine-grained graywacke mixed with black slate. Conglomerate layers near the top of the lens are rarely more than 2 feet thick and contain granule-sized particles of the same rock types.

At fossil locality 0-2, dark-gray, strongly foliated, fine- to mediumgrained calcareous lithic graywacke containing thin partings of black 
slate is exposed in Kamankeag Brook. Chips of black slate and, to a lesser extent, green slate and chert, as much as 1 inch long, are scattered in a matrix of quartz, feldspar, muscovite, chlorite, and calcite. Pyrite, zircon, and carbonaceous material of unknown composition are present in minor amounts. Two measured modes of the lithic graywacke are given in table 2 (samples 1,2 ; see also fig. 5 ). The calcite occurs as very fine grained interstitial material and as larger perforated fossil fragments. Arcuate pits, some with distinct ribbing, are common in the weathered rock indicating that the graywacke locally contains abundant fragments of shelly fossils.

Fossils from locality 0-2 were studied by R. B. Neuman of the U.S. Geological Survey, who reported abundant fragments of bryozoans, pelecypods, gastropods, pelmatozoans, and brachiopods, all too badly deformed for generic identification. One brachiopod, identified as either Bilobia or Diambonia by Neuman, is compatible with the Middle Ordovician age established by the graptolites from fossil locality 0-1.

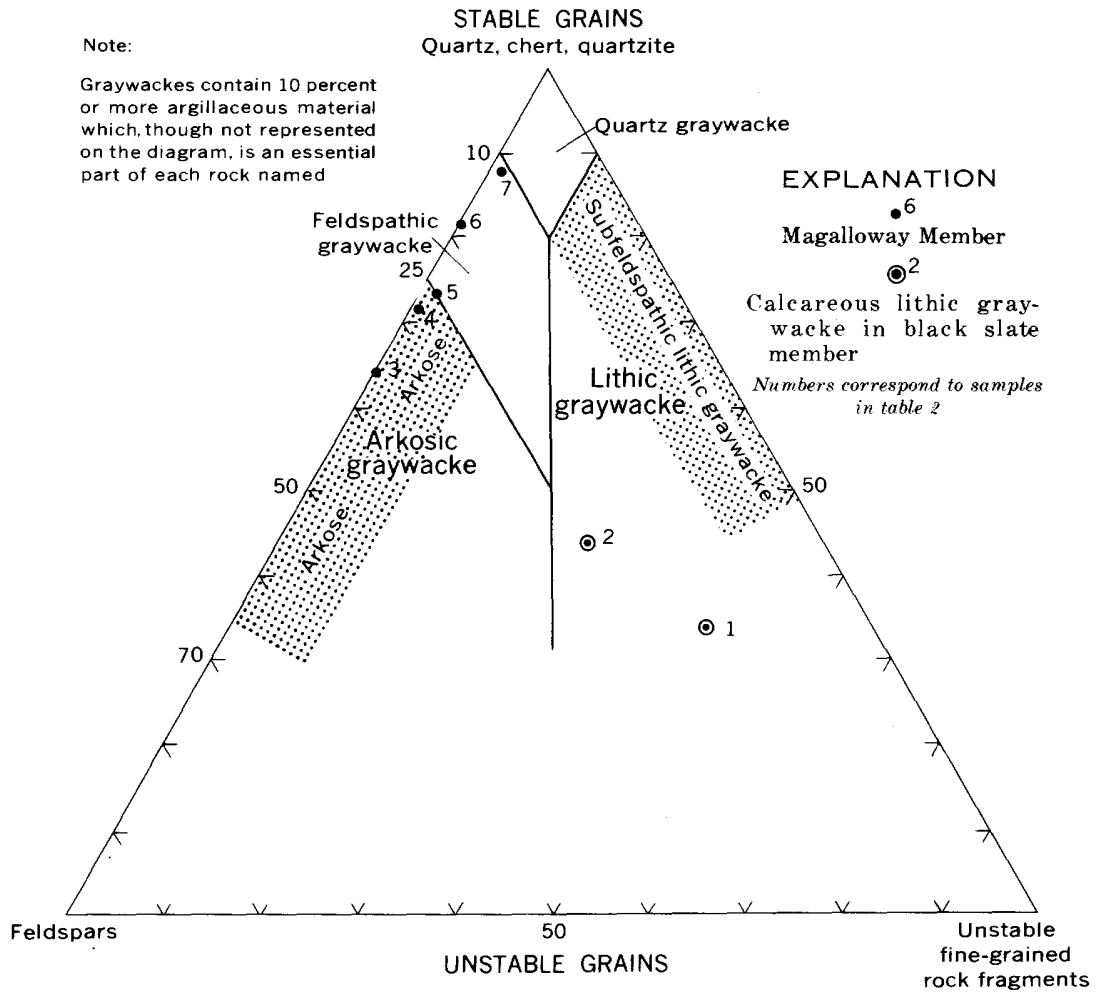

Figure 5.-Classification of graywacke (modified from Williams and others, 1954, p. 292) with plots of graywacke samples from the Dixville Formation. 
TABLE 2.-Measured modes and ternary compositions of gray'wacke from the black slate member and Magalloway Member of the Dixville Formation, Cupsuptic quadrangle, Maine

[See figure 5 for graywacke classification of samples]

\begin{tabular}{|c|c|c|c|c|c|c|c|}
\hline Sample & 1 & 2 & 3 & 4 & 5 & 6 & 7 \\
\hline Point counts...- & 503 & 517 & 757 & 780 & 650 & 744 & 570 \\
\hline
\end{tabular}

\section{Measured modes}

\begin{tabular}{|c|c|c|c|c|c|c|c|}
\hline Quartz. & 13.7 & 27.8 & 39.2 & 35.8 & 84 & 52. 1 & 34.8 \\
\hline Feldspar... & 7.4 & 16.2 & 23.1 & 14.1 & 12.9 & 12.4 & 4. 4 \\
\hline Rock fragments.......... & 19.7 & 20.2 & .3 & .6 & 1. 2 & .3 & 1. 0 \\
\hline Chlorite & 1. 2 & 1. 0 & .3 & 1.7 & .6 & .7 & 1. 4 \\
\hline Muscovite. & 2 & .4 & .3 & .2 & 6 & .5 & .2 \\
\hline Calc te & 33.0 & $3 . \overline{3}$ & 4 & 2.8 & 0 & 1.9 & .0 \\
\hline Matrix & 21.7 & 30.1 & 35.6 & 43.5 & 45. 0 & 31.8 & 56. 7 \\
\hline Other 1 & 3.2 & .8 & .8 & 1.3 & 1. 1 & .4 & 1.4 \\
\hline Total ............ & 100.1 & 99.8 & 10.0 & 100.0 & 99.8 & 100.1 & 99.9 \\
\hline
\end{tabular}

Ternary compositions

\begin{tabular}{|c|c|c|c|c|c|c|c|}
\hline $\begin{array}{l}\text { Quartz } \\
\text { Feldspar } \\
\text { Rock fragments. }\end{array}$ & $\begin{array}{l}34 \\
18 \\
48\end{array}$ & $\begin{array}{l}43 \\
25 \\
32\end{array}$ & $\begin{array}{r}63 \\
37 \\
0\end{array}$ & $\begin{array}{r}71 \\
28 \\
1\end{array}$ & $\begin{array}{r}73 \\
25 \\
2\end{array}$ & $\begin{array}{r}81 \\
19 \\
0\end{array}$ & $\begin{array}{r}87 \\
11 \\
2\end{array}$ \\
\hline Total & 100 & 100 & 100 & 100 & 100 & 100 & 100 \\
\hline
\end{tabular}

1 Includes zircon, tourmaline, epidote, magnetite, pyrite, and carbonaceous material.

Black slate member:

Location of samples

1. At 1,680 feet altitude in Kamankeag Brook.

2. Top of 1,940 -foot knob, 2,500 feet (bearing $023^{\circ}$ ) from county line-Kamankeag Brook crossing. Magalloway Member:

3. Top of 2,140-foot knob immediately north of confluence of Bear Brook and Kennebago River.

4. Top of 2,669-foot knob, 3,500 feet (bearing $305^{\circ}$ ) irom 1,922-foot bench mark on Beaver Pond Tote Road.

5. At 1,940 feet altitude in Crowley Brook.

6. At 2,000 feet altitude, 3,700 feet (berring $326^{\circ}$ ) from 1,869 -foot bench mark on Beaver Pond Tote Road.

7. At 2,400 feet altitude in Sable Mill Brook.

The lens of calcareous lithic graywacke and conglomerate is concluded to represent a thin, intraformational flysch deposit rather than a major break in the depositional record because (1) beds in the lens and the black slate member are conformable, (2) the graywacke contains chaotically deformed wispy lenticles of black slate identical to the black slate enclosing the lens, and (3.) the graywacke lens contains abundant fragments of various fossils that lived, died, and were apparently fragmented within a littoral marine environment rather than in the euxinic environment that produced the surrounding black slate.

\section{QUARTZITE}

Dark-gray, fine- to medium-grained quartzite interbedded with black phyllite is found at scattered localities on the north limb and nose of the Black Cat anticline, 1,000 to 3,000 feet above the base of the black slate member. Quartzite constitutes more than 50 percent 
of an exposure in these localities. It is believed to form an essentially continuous lithologic zone about 200 feet thick in the black slate member. Primary sedimentary structures are not common in the quartzite beds, which range in thickness from 0.5 to 5 feet and alternate with beds of black slate about 0.5 to 1 foot thick.

The quartzite is composed primarily of subrounded quartz and contains lesser amounts of albite, muscovite, chlorite, and pyrite. Quartzpebble meta-conglomerate, containing rounded clasts of white vein quartz and minor chert and quartzite pebbles as much as 1 inch in diameter, locally forms lenses a few feet thick in the quartzite zone southwest of Bottle Mountain and at the southwest end of Parmachenee Lake (pl. 1).

The quartzite zone is conformable within and gradational into the black slate member and thus does not appear to mark a major break in the sedimentary record.

\section{MAGALLOWAY MEMBER}

The Magalloway Member is a heterogeneous unit, consisting primarily of feldspathic graywacke interbedded with variable amounts of metavolcanic rocks and slate. It overlies the black slate member in the northern part of the Cupsuptic quadrangle and apparently overlies intermixed greenstone and black slate in the northwest part of the Arnold Pond quadrangle. (See Harwood (1969a).) Biotite gneiss in the eastern part of the Arnold Pond quadrangle is tentatively assigned to the Magalloway Member because it is interlayered with contact-metamorphosed graywacke west of, and in roof pendants within, the Seven Ponds pluton (pl.1).

Graywacke makes up about 90 percent of the member and is interbedded with green, purplish-gray, or black slate and light-green schistose felsic metavolcanic rocks. Relatively thin but locally continuous layers of greenstone have been mapped as lenticular units within the Magalloway Member on Thrasher Peaks and north of White Cap Mountain (pl. 1).

\section{GraYwacke}

Graywacke is used here as defined in Williams, Turner and Gilbert (1954), p. 289-294) to mean an impure sandstone containing 10 percent or more of argillaceous matrix which encloses poorly sorted stable (quartz, quartzite, chert) and unstable (feldspar and rock fragments) grains. The ratio of stable grains, feldspar, and rock fragments is used to subdivide the graywacke clan into compositional classes. On this basis, the arenaceous rocks in the Magalloway Member range from arkosic graywacke to feldspathic graywacke (fig. 5). These gray- 
wacke classes could not be distinguished from each other in the field and, indeed, two or more classes may intergrade in one outcrop.

Gray wacke in the chlorite zone of metamorphism is dark green, gray, or rusty brown and generally weathers to a rough chalky gray or vitreous surface depending on the quartz content. Variations in grain size from silt to granule arkosic conglomerate are common and may be cubrupt or gradational over several inches. The fine-grained varieties are crudely foliated to schistose, whereas the coarse-grained varieties are generally massive. Beds in the graywacke range in thickness from less than 1 inch to about 10 feet and generally vary in thickness, commonly pinching out completely, in an exposure. Primary sedimentary structures such as graded bedding, sole markings, and channelling are not common.

Quartz, quartzite, alkali feldspar, plagioclase, muscovite, green slate, and chert occur as detrital grains in a matrix of sericite, chlorite, quartz, and feldspar (fig. 6). The quartz clasts are glassy, white, light blue, or hematite stained, are subangular to subrounded, and range in size from $0.1 \mathrm{~mm}$ to $10 \mathrm{~mm}$. Rutilated quartz grains are common. Clasts of

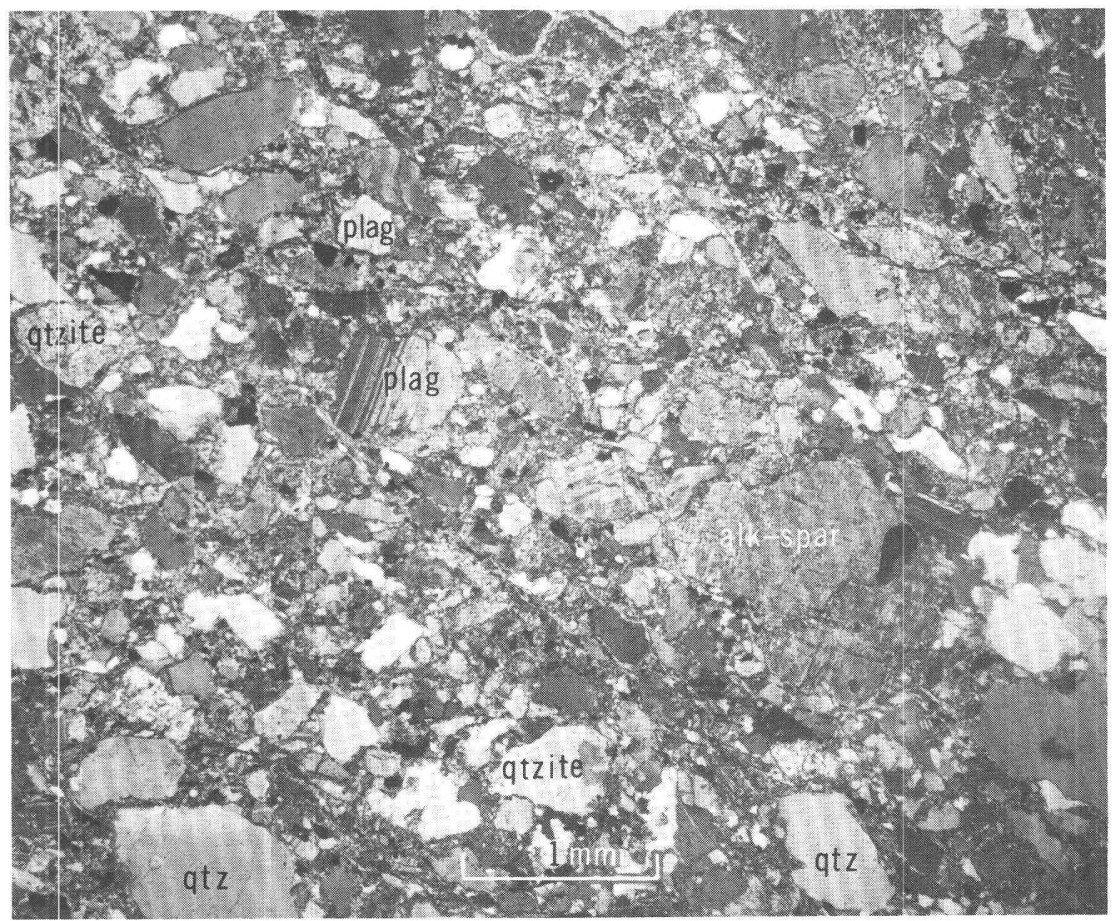

FIGURE 6.-Photomicrograph of arkosic graywacke from Magalloway Member of Dixville Formation (table 2, sample 3). Crossed polarizers, qtzite, quartzite; plag, plagioclase ; alk-spar, alkali feldspar; qtz, quartz. 
polycrystalline quartz, having sutured grain boundaries and strain lamellae, may be quartzite or vein quartz. Relatively fresh subangular plagioclase is associated with highly sericitized, subrounded microcline perthite and plagioclase. Muscovite flakes, as much as $2.0 \mathrm{~mm}$ long, appear as bent and partly altered clastic grains in the fine-grained matrix. Zircon grains commonly have rounded overgrowths around euhedral cores and are associated with euhedral tourmaline in all thin sections of the graywacke. Locally, the graywacke has a siliceous matrix that deeply embays and serrates the edges of the clastic grains.

\section{Green and Purplish-Gray Slate}

Green and, locally, purplish-gray slate form layers and discontinuous patches in the graywacke. The slate layers are commonly less than 10 feet thick and are nonbedded.

\section{Blagk Slate}

Black slate, identical to that of the black slate member of the Dixville, occurs in several isolated exposures in the road east of the First East Branch of the Magalloway River about half a mile south of the international boundary ( $\mathrm{pl} .1$ ). Although the exact stratigraphic relations of these slate outcrops is unknown, the black slate is inferred to be interlayered in the graywacke. Similar layers of black slate in graywacke are exposed west of Twin Peaks in the western part of the Arnold Pond quadrangle (pl.1).

\section{Biotite Gneiss}

In the eastern part of the Arnold Pond quadrangle, rocks of the Magalloway Member have been contact metamorphosed to massive biotite gneiss or faintly banded biotite gneiss adjacent to the Seven Ponds pluton (pl. 1). Much of this biotite gneiss is dark gray to silver gray, medium to coarse grained, and massive to crudely schistose. Thin, wispy, biotite-rich layers form less than 10 percent of the massive gneiss, and rounded masses of clear to milky white, granular quartz about 1 inch in diameter are scattered throughout the rock. In addition to these quartz knots-which may be pebbles, or metamorphic segregations, or both-the massive gneiss also contains rounded, light-gray, quartz-feldspar-rich clasts and dark-gray biotite-rich clasts 0.5 to 3 inches in diameter. The massive gneiss is composed of quartz, plagioclase, biotite, muscovite, and magnetite; chlorite is present in the biotite zone, and andalusite or sillimanite, or both, are present in pelitic layers in the andalusite and sillimanite zones. The massive gneiss is not separated from the graywacke of the Magalloway Member on plate 1. 
Well-layered biotite gneiss forms a narrow belt around the western side of the Seven Ponds pluton and appears to be interlayered with massive gneiss in the roof pendants east of Massachusetts Bog (pl. 1). The well-layered gneiss is characterized by alternating light-gray, quartz-feldspar-rich layers and dark-gray to black, biotite-rich layers 0.5 to 8 inches thick. Andalusite or sillimanite, or both, are present in the biotite-rich layers, and microcline and garnet occur locally in the more granular layers.

Although the well-layered gneiss is mapped as a separate rock type, the stratigraphic relations between the well-layered gneiss and massive gneiss could not be determined due to the lack of primary sedimentary structures. Because the well-layered gneiss appears to be interlayered with massive gneiss which represents the contact-metamorphosed graywacke of the Magalloway Member, it is concluded that the well-layered gneiss is a lithofacies of the Magalloway Member. Future work in the Chain Lakes quadrangle to the east, however, may show that these gneisses are not equivalent in age.

\section{Lentigular Greenstone Units}

Two lenticular units of dark-green to dark-gray greenstone have been mapped in the Magalloway Member; one is north of White Cap Mountain in the northeast corner of the Cupsuptic quadrangle and the other is along the southeast slope of Thrasher Peaks in the northwest corner of the Cupsuptic quadrangle and the adjacent part of the Arnold Pond quadrangle.

The lens near White Cap Mountain is of varied composition and contains light-green epidote-rich layers alternating with dark-green actinolite-rich layers about 3 inches thick. Discontinuous layers of agglomerate or volcanic breccia occur near Dennison Bog and south of the serpentinite body on the east slope of White Cap Mountain. Locally, the greenstone contains layers and masses of magnetite- and hematite-rich chert a few inches thick that are associated with purple or red slate. Areas where this iron-rich horizon were found are shown by the circled letter "M" on plate 1; similar rocks in Quebec, about 1 mile on strike to the west of Dennison Bog, contain chalcopyrite and galena. No base-metal sulfides were found in the lens of greenstone north of White Cap Mountain.

The greenstone lens on Thrasher Peaks contains light- and darkgreen layers that vary principally in the ratio of actinolite and chlorite to feldspar and quartz. The layers are 10 to 30 feet thick. Unlike the greenstone lens near White Cap Mountain, the lens on Thrasher Peaks contains well-preserved pillow structures that are locally outlined by gray-green or red chert. Volcanic agglomerate or breccia is 
present in the Thrasher Peaks greenstone lens, but the magnetitehematite-rich chert was not found.

\section{ROGKS OF ORDOVICIAN AND SILURIAN AGE}

A sequence of metamorphosed sedimentary and volcanic rocks, unlike any in the surrounding Magalloway Member of the Dixville, is found in narrow roof pendants in the quartz monzonite north and south of Arnold Pond (pl. 1). The order of superposition, determined from graded beds shown on inset maps B and C of plate 1 is (1) sulfidic black hornfels and feldspathic quartzite containing layers of amphibolite, (2), cyclically bedded white quartzite and gray nonsulfidic hornfels, and (3) sulfide black hornfels and feldspathic quartzite similar to the lowest unit in this sequence. Discontinuous layers of massive white quartzite and quartz-granule metaconglomerate occur near or at the base of the cyclically bedded quartzite and gray hornfels. Several small bodies of serpentinite are in contact with the lower black hornfels and amphibiolite unit, but none intrude the cyclically bedded quartzite and gray hornfels.

The Sulfidic black hornfels is not in contact with rocks of the Magalloway Member of the Dixville Formation although on the ridge east of Massachusetts Bog (pl. 1), a separate roof pendant of black hornfels occurs between roof pendants of well-layered biotite gneiss of the Magalloway suggesting that the two rock types may be interlayered. The lower contact of the cyclically bedded quartzite and gray hornfels with the black hornfels is sharp and conformable. The cyclically bedded unit is in contact with the well-layered biotite gneiss of the Magalloway Member about 1.5 miles east of Massachusetts Bog (pl. 1), and this contact is also sharp and apparently conformable. The upper contact of the cyclically bedded quartzite and gray hornfels with the overlying black hornfels is exposed north of Arnold Pond (pl. 1, inset map C). The two rock types are intensely folded but the contact is sharp and conformable.

The lower unit of sulfidic black hornfels has a maximum thickness of 400 feet; the cyclically bedded quartzite and gray hornfels is about 250 feet thick; and the upper sulfidic black hornfels is at least 350 feet thick. The discontinuous layers of massive white quartzite and quartz-granule metaconglomerate in the cyclically bedded unit range in thickness from 0 to 35 feet.

The age of these rocks is unknown, but they are clearly older than the quartz monzonite which intrudes them and equal to or younger than the Magalloway Member which lies stratigraphically below them; therefore, a Middle Ordovician to Middle Devonian age is possible. Sulfidic black hornfels associated with amphibolite and serpentinite 
correlates most closely with similar rocks in the Magalloway Member of the Dixville found north of White Cap Mountain (pl. 1). The cyclically bedded quartzite and gray hornfels associated with massive quartzite and quartz-granule metaconglomerate, on the other hand, are similar to basal Silurian rocks described in a later section of this report. From lithologic correlation only it seems most likely that the lower sulfidic black hornfels, amphibolite, and serpentinite are Middle Ordovician and the overlying quartzite and gray hornfels are Silurian. If this reasoning is correct the upper black hornfels above the quartzite and gray hornfels must be Silurian or possibly Devonian, or both; alternatively, this entire sequence of rocks may be pre-Silurian. Lacking definitive evidence for the age of these rocks, they are herein considered to be Middle Ordovician to Silurian because they are lithologically similar to known Middle Ordovician and Silurian rocks in this area.

\section{BLACK HORNFELS AND AMPHIBOLITE}

Rusty weathering, sulfidic black hornfels makes up most of the narrow roof pendants south of Arnold Pond (pl. 1). This rock is well exposed on the group of low hills about 1 mile west of Otter Pond and, to a lesser extent, on the 1,840-foot hill north of Arnold Pond.

The rock is fine to medium grained, is commonly massive to crudely foliated, and contains discontinuous layers of medium- to coarsegrained, sulfidic, feldspathic quartzite. The arenaceous beds are present in variable proportions but they generally make up less than 10 percent of an outcrop; the remainder is metamorphosed pelitic rock. The arenaceous beds, which are as much as 2 feet thick, pinch and swell along strike and tend to be irregularly separated by highly variable thicknesses of pelitic rock.

The black hornfels is composed of quartz, muscovite, plagioclase, biotite, cordierite, sillimanite, zircon, pyrrhotite, and finely divided opaque material that may be graphite. Locally, muscovite is absent, or nearly so, and microcline is the dominant potassium-rich mineral. Andalusite may be present in addition to sillimanite. The feldspathic quartzite is composed primarily of quartz, plagioclase, biotite, and muscovite and contains lesser amounts of sillimanite, cordierite, zircon, tourmaline, and pyrrhotite.

Thin layers of fine- to coarse-grained dark-green amphibolite, generally less than 50 feet thick, are found between the black hornfels and the serpentinite bodies north of Arnold Pond (pl. 1, inset map C) and about 1.5 miles west of Otter Pond (pl. 1). Amphibolite also occurs west of the serpentinite borly northwest of Crosby Pond (pl. 1).

Most of the amphibolite is coarse grained, massive, intensely fractured and contains no recognizable primary structures. It is composed 
of dark-green hornblende, saussuritized plagioclase, biotite, calcite, epidote, and magnetite. A discontinuous layer of finely laminated and streaked, light-green and white, fine-grained amphibolite about 10 feet thick occurs locally between the coarse-grained amphibolite and the black slate hornfels. This finely laminated amphibolite appears to be a metamorphosed calcareous siltstone or tuff, whereas the massive amphibolite appears to be a metamorphosed mafic volcanic rock.

\section{QUARTZITE AND GRAY HORNFELS}

The cyclically bedded quartzite and gray hornfels unit is well exposed on the 1,840-foot hill north of Arnold Pond (pl. 1, inset map C), in the brook between Arnold Pond and Mud Pond, and in several thin roof pendants on the ridges between Otter Pond and Massachusetts Bog Stream (pl. 1).

Outcrops characteristically contain alternating beds of fine- to medium-grained, well-sorted, white to light-gray quartzite and dark-gray, fine-grained pelitic hornfels interbedded in about equal proportions to produce a cyclically bedded rock. The quartzite beds, which range in thickness from 1 to 4 inches, are commonly graded and are separated by beds of nonfoliated gray hornfels about 4 inches thick. The quartzite beds range from thin continuous layers to anastomosing lenses and beds. The lowermost 10 to 15 feet of the cyclically bedded unit is composed predominantly of dark-gray hornfels that contains widely separated beds of quartzite about 4 inches thick.

In the roof pendant that crops out about 1 mile west of Otter Pond (pl. 1, inset map B), the base of the cyclically bedded unit is marked by a discontinuous layer of quartz-granule metaconglomerate. The clasts of the metaconglomerate are flattened, white to light-gray, granular quartzite and colorless quartz grains set in a light-gray matrix of fine-grained biotitic quartzite. Paper-thin biotite laminations curve around the flattened quartz-rich clasts and give the metaconglomerate a streaked appearance and platy fracture. In addition, near the base of the cyclically bedded unit in this roof pendant, a discontinuous layer of massive white vitreous quartzite about 15 feet thick forms a pronounced hogback ridge about 10 feet high adjacent to the logging road shown in inset map $B$ of plate 1.

The quartzite beds of this unit are composed of more than 90 percent subrounded quartz and contain minor biotite, muscovite, zircon, and tourmaline. The dark-gray hornfels is predominantly composed of quartz, plagioclase, biotite, muscovite, sillimanite, zircon, and tourmaline. Cordierite is present in some of the gray hornfels, but is not as common in this rock as it is in the sulfidic black hornfels. 


\section{ROGKS OF SILURIAN AGE}

Polymict and quartz-pebble metaconglomerate, quartzite, calcareous slate, and metalimestone-ranging in age from Early Silurian (late Llandovery) to Late Silurian (Ludlow or Pridoli) - form lenticular units that rest unconformably on the pre-Silurian rocks in three widely separated parts of the map area. The Silurian rocks, in contrast to those of pre-Silurian age, are relatively thin and discontinuous and remarkably varied in composition.

Silurian rocks exposed north and south of Johns Pond (pl. 1) in the southeastern part of the Cupsuptic quadrangle are assigned to the Rangeley Formation. These rocks have been divided into a polymict metaconglomerate member, a quartz-pebble metaconglomerate member, and a well-bedded slate and quartzite member. The conglomerate members have been dated as late Llandovery by fossils found 6 miles on strike to the northeast and reported by E. L. Boudette (U.S. Geol. Survey, 1965, p. A74). The overlying slate and quartzite member is probably Llandovery in age because its lower part interfingers with the polymict conglomerate; the upper part, however, may be somewhat younger (Ludlow?).

Unnamed Silurian rocks found in an outlier east of Parmachenee Lake include an argillite and metatuff member, a metaconglomeratequartzite member, an argillaceous metalimestone member, and an arenaceous metalimestone member. The youngest member, the arenaceous metalimestone, has been dated by fossils as Pridoli (Late Silurian) by A. J. Boucot (written commu., 1967). The underlying members may range in age from Early to Late Silurian.

Small patches of polymict metaconglomerate and a thin, but somewhat more extensive, layer of calcareous slate and metalimestone, unnamed in this report, form the basal Silurian rocks in the northwest corner of the Cupsuptic quadrangle and the adjacent part of the Arnold Pond quadrangle. The calcareous slate and metalimestone has been tentatively dated as Late Silurian (Ludlow?) by Naylor and Boucot (1965) and by Green (1968, p. 1615). The conglomerate may be Early or Late Silurian in age by analogy with other conglomerates in the area.

Several features of the Silurian rocks suggest they were deposited in a transgressive sea which encroached from the southeast onto a rapidly eroding positive area referred to as Somerset Island by Naylor and Boucot (1965) and the Somerset geanticline by Cady (1967). Perhaps the most significant feature in this respect in the map area is the pronounced decrease in the amount of coarse polymict metaconglomerate toward the northwest and the reciprocal increase in the same direction of the more stable quartz-pebble metaconglomerate asso- 
ciated with calcareous slate and metalimestone. It could be argued that all these Silurian units are simply coeval lithofacies, except that the conglomerate in the southeastern part of the Cupsuptic area is late Llandovery in age and the limestone at the base of the Silurian section in the northwestern part of the map area is most probably Ludlow in age.

\section{RANGELEY FORMATION}

The name Rangeley Conglomerate was given by Smith (1923) to a polymict metaconglomerate exposed in the Rangeley quadrangle (fig. 1). Osberg, Moench, and Warner (1968) revised the Rangeley Conglomerate to include overlying metasandstone and metashale units and adopted the unit as the Rangeley Formation. The name is used here for a lithologically similar but thinner sequence of rocks exposed at the west end of a small syncline near Johns Pond (pl. 1) in the southeast part of the Cupsuptic quadrangle. The formation consists of a polymict metaconglomerate member 0 to 1,100 feet thick on the south limb of the syncline, a quartz-pebble metaconglomerate member 0 to 450 feet thick on the north limb of the syncline, and a slate and quartzite member about 2,600 feet thick that overlies the quartz-pebble metaconglomerate and overlies and interfingers with the polymict metaconglomerate member.

The matrix of the polymict metaconglomerate contains scattered fragments of brachiopods and small horn corals at fossil locality S-1, and boulders of limestone within the metaconglomerate contain corals at fossil locality S-2 (pl. 1). A. J. Boucot (written commun., 1966) identified the brachiopod fragments in the matrix as either Eoplectodonta or Plectodonta. The corals in the matrix were studied by W. A. Oliver, but they are preserved as molds that are not diagnostic. Oliver (written commun., 1965) found numerous recrystallized halysitid and horn corals in the limestone boulders from fossil locality S-2 and identified the halysitid coral as Catenipora (?) sp. None of these fossils gives a definitive age for the polymict metaconglomerate, but all are compatible with the late Llandovery age established by brachiopods found in the overlying quartz-pebble metaconglomerate 6 miles on strike to the northeast by E. L. Boudette (U.S. Geol. Survey, 1965, p. A74). Thus, a late Llandovery age (Early Silurian) is tentatively established for the basal conglomerate members of the Rangeley Formation in the Cupsuptic quadrangle.

\section{POLYMIGT METAGONGLOMERATE MEMBER}

Polymict metaconglomerate that contains variable amounts of interbedded feldspathic quartzite is well exposed on the southeast and west slopes of the 2,780-foot hill between Johns Pond and Kamankeag Pond 
(pl. 1) and at scattered localities along the 2,200-foot contour half a mile north of Kamankeag Pond. The rocks are inferred to rest unconformably upon the Dixville and Albee Formations, and they form the lowest member of the Rangeley Formation in the Cupsuptic quadrangle.

Near the base of the member, the polymict metaconglomerate contains clasts of black slate, granitic rocks, vein quartz, light-gray quartzite, green phyllite, and minor amounts of greenstone, felsite, and light-gray coarsely crystalline limestone. The clasts range in size from pebbles about 1 inch in diameter to boulders as much as 2 feet in diameter. The clasts of granitic rocks, vein quartz, and quartzite are well rounded and nearly spherical, whereas the fragments of black slate and green phyllite are platy and angular and have a pronounced cleavage. Cleavage in the slate fragments is parallel to or subparallel to cleavage in the argillaceous rocks above the polymict metaconglomerate member. The clasts of black slate, green phyllite, quartzite, vein quartz, and greenstone were apparently derived from the underlying pre-Silurian rocks. The origin of the granitic clasts is not known, but they may have been derived from the Adamstown Granite of Green and Guidotti (1968) in the northern part of the Oquossoc quadrangle (fig. 1), or from the small granodiorite plutons of inferred Ordovician age in the Cupsuptic quadrangle, or from the large quartz monzonite bodies of Ordovician age found at the nose of the Boundary Mountain anticlinorium (Albee, 1961). The coral-bearing limestone boulders probably were derived from local Silurian encrustations or small reef deposits that were broken up by the influx of coarse detritus. There are no known layers of coarsely crystalline limestone in the surrounding Silurian or pre-Silurian rocks.

The matrix of the metaconglomerate is coarse-grained feldspathic quartzite composed of subangular to subrounded grains of quartz, alkali feldspar, plagioclase, and lesser amounts of microscopic muscovite, chlorite, and calcite. The metaconglomerate is not distinctly stratified near the base.

In the middle and upper parts of the member the clasts are predominantly vein quartz, light-gray quartzite, and granite; minor amounts of green phyllite, black slate, and greenstone clasts are also present. No limestone fragments were found above the basal 50 feet of the member. The clasts are well rounded, range in diameter from about 0.25 to 4 inches, and are set in a matrix of fine- to mediumgrained feldspathic quartzite which is identical in composition and appearance to the interlayered feldspathic quartzite beds. The metaconglomerate beds range in thickness from about 1 to 10 feet, and the feldspathic quartzite beds are generally less than 1 foot thick. Channel- 
and-fill structures are common. Pebbles and small cobbles similar to those in the metaconglomerate beds are present locally as isolated clasts in the feldspathic quartzite beds.

\section{QUARTZ-PEBBLE METAGONGLOMERATE MEMBER}

Quartz-pebble metaconglomerate is exposed in scattered outcrops and as abundant float in a belt that extends from the 2,300-foot knob southwest of Grants Camps to the west end of the 2,780-foot hill due south of Johns Pond (pl. 1). A thin, discontinuous patch of the quartzrebble conglomerate, separated from the main syncline but tentatively correlated with the main body on the basis of lithologic similarity, is exposed along the west bank of the Kennebago River near the 1,566foot bench mark on the abandoned Maine Central Railroad grade.

The quartz-pebble metaconglomerate member is inferred to rest unconformably upon the Albee Formation on the north limb of the Johns Pond syncline (pl. 1) and conformably above the polymict metaconglomerate member on the south limb of the syncline. The contact between the basal members of the Rangeley Formation and the underlying pre-Silurian rocks was not seen, but the unconformable relationship is inferred from widely divergent bedding attitudes in the Silurian and pre-Silurian rocks and from the fact that the Silurian units truncate both the Albee and Dixville Formations.

The member is composed predominantly of light-gray or tannishgreen quartz-pebble conglomerate that locally is mottled jet black to rusty $\tan$ on the weathered surface where iron oxide stain outlines the quartz pebbles. Most of the clasts are milk-white to colorless vein quartz, but minor amounts of black chert, gray quartzite, and green phyllite clasts are also present. The quartz clasts are rounded to subrounded, nearly spherical to ovoid in shape, and range from granules about $3.0 \mathrm{~mm}$ in diameter to pebbles about $3.0 \mathrm{~cm}$ in maximum diameter. The green phyllite fragments are platy, angular, highly foliated, and commonly less than $1.0 \mathrm{~cm}$ in maximum diameter. The matrix is yellow green, has a resinous luster, and consists of an aggregate of quartz, chlorite, and muscovite; a crude foliation is present where chlorite and muscovite constitute more than 10 percent .of the rock. Siliceous cement is present locally.

The basal part of the member is not visibly bedded, but the upper part contains beds of medium- to coarse-grained quartzite as much as 3 feet thick. The beds are rarely graded.

\section{SLATE AND QUARTZITE MEMBER}

The slate and quartzite member is well exposed on the south slope and top of the 2,960-foot mountain southeast of Johns Pond (pl. 1) where it interfingers with the polymict metaconglomerate member. 
The facies relations between these members is well exposed east of the small swamp on the ridge between Johns Pond and Kamankeag Pond (pl.1).

The slate and quartzite member consists of dark-gray, soft, chalkyweathering slate and dark- to light-gray, fine- to coarse-grained feldspathic quartzite (including some metasiltstone) interbedded in variable proportions. Tongues and lenses of granule polymict metaconglomerate are common near the contact with the polymict metaconglomerate member. The rock is characteristically well bedded, particularly in the upper part where graded feldspathic quartzite beds 0.25 to 3 inches thick alternate with slate beds 2 to 12 inches thick. Locally, near the base of the unit, the feldspathic quartzite is calcareous and weathers to punky brown seams about 1 inch thick.

The slate is composed of microscopic quartz, muscovite, albite, and chlorite and minor amounts of pyrite and zircon. The feldspathic quartzite contains quartz, albite, and muscovite and lesser amounts of chlorite, calcite, alkali feldspar, sphene, and pyrite. The quartz and feldspar grains are angular to subangular and range in diameter from about $20 \mu$ to about $0.1 \mathrm{~mm}$.

\section{UNNAMED ROCKS IN THE VICINITY OF PARMACHENEE LAKE}

An unnamed sequence of argillite, metaconglomerate, and metalimestone about 2,300 feet thick is exposed on the low hills east of Parmachenee Lake (pl. 1) in an outlier containing a doubly plunging faulted syncline (p. 1, inset map A). The outlier is surrounded on three sides by the black slate member of the Dixville Formation, and on the west, by Parmachenee Lake. South of the east-trending normal fault that approximately bisects the outlier the lowest member in the sequence consists of laminated, gray argillite and felsic metatuff about 500 feet thick; it is overlain by the metaconglomerate and quartzite member, which ranges in thickness from 0 to 1,100 feet. North of the fault, the metaconglomerate and quartzite member is at the base of the sequence and is overlain by the argillaceous metalimestone member that is about 250 feet thick. The argillaceous metalimestone member is overlain by the arenaceous metalimestone member that has a maximum thickness of about 450 feet.

The arenaceous metalimestone contains abundant brachiopods and corals at fossil locality S-3 (pl. 1) and has been dated as Late Silurian (Pridoli) by A. J. Boucot (written commun., 1965) on the basis of the brachiopod Eccentricosta. The underlying members may range in age from Early to Late Silurian, but all must be younger than Middle Ordovician because they form a sequence resting unconformably on the Dixville Formation. 


\section{ARGILLITE AND METATUFF UNIT}

The argillite and metatuff unit is exposed in the vicinity of the broad 1,900-foot knob on the south side of the small swamp northeast of Parmachenee Lake and in the lower reaches of Moose Brook (pl. 1). The unit is inferred to lie unconformably above the black slate member of the Dixville Formation, but the actual contact was not seen.

Massive greenish-gray and less commonly well-layered dark- to light-gray argillite make up more than 90 percent of the unit. Bedding is generally difficult to see except in the stream-washed outcrops of Moose Brook, where alternating light- and dark-gray argillite layers 1 to 3 inches thick give the rock a varved appearance.

Thin discontinuous beds of light-green to greenish-white, extremely fine grained metatuff(?) commonly a few inches thick, but locally several feet thick, are scattered throughout the argillite. Primary structural features are not present; thus, it is difficult to determine whether this rock originated as pyroclastic ash or as thin lava flows, or whether it is, in fact, a feldspathic siltstone. Its extremely fine grain size and the absence of flow structures, however, suggest a pyroclastic or sedimentary origin, or both. Feldspar is the major constituent, so the tuff classification is favored. Exposed surfaces of the metatuff weather to a soft, chalky white rind less than $1.0 \mathrm{~mm}$ thick:

The argillite is composed of microscopic quartz, feldspar, chlorite, and muscovite and minor amounts of clinozoisite, zircon, and tourmaline. The metatuff is composed predominantly of microscopic feldspar and contains lesser amounts of quartz, white mica, and chlorite.

\section{METACONGLOMERATE AND QUARTZITE UNIT}

The metaconglomerate and quartzite unit underlies the higher ridges and knobs north and south of the east-trending central fault. North of the fault the unit is predominantly quartz-pebble metaconglomerate, whereas south of the fault, gray quartzite predominates and is interbedded with minor amounts of polymict metaconglomerate, dark-gray calcareous quartzite, and dark-gray to black slate.

The quartz-pebble metaconglomerate is dark gray or greenish gray and contains clasts of fine-grained gray quartzite, milky white or reddish vein quartz, and gray chert, plus minor amounts of feldspar and green phyllite. The clasts, which are commonly subrounded or platy, range in diameter from about 0.5 to about 3 inches. Adjacent to the faults the clasts have been slightly elongated. The matrix is composed primarily of subangular quartz and feldspar, generally less than $0.1 \mathrm{~mm}$ in diameter, and contains lesser amounts of microscopic chlorite and muscovite. 
On the north limb of the syncline, beds of greenish-gray quartzite, which are commonly graded and range in thickness from 1 to 4 feet, are present in the metaconglomerate. The quartzite is composed of subangular grains of quartz and minor amounts of feldspar, about $50 \mu$ to $0.2 \mathrm{~mm}$ in diameter, and finer grained chlorite and muscovite. Minor amounts of red slate are interbedded with the conglomerate on the 2,060-foot knob 1 mile northeast of the Parmachenee Club (pl. 1).

South of the fault the metaconglomerate and quartzite unit is composed predominantly of dark-gray to gray-green vitreous quartzite. The quartzite is commonly massive but locally contains beds of darkgray slate which range in thickness from 1 to 10 inches and alternate with beds of quartzite generally 3 to 5 feet thick. Graded bedding is not common. Near the top of the quartzite unit, dark-gray to black slate is more abundant and forms beds a few inches thick that alternate with beds of dark-gray to rusty brown, calcareous quartzite 1 to 6 inches thick.

The quartzite is composed of subangular grains of quartz, plagioclase, alkali feldspar, and chert, plus minor amounts of chlorite, muscovite, tourmaline, and locally calcite. The quartz grains range in diameter from about $20 \mu$ to $0.2 \mathrm{~mm}$.

A thin discontinuous lens of polymict metaconglomerate is found at the contact between the conglomerate and quartzite unit and the argillite and tuff unit in the vicinity of the 1,960-foot knob 4,000 feet due east of the Parmachenee Club (pl. 1). The clasts are predominantly light-gray felsite porphyry, black chert, gray quartzite, granodiorite, and green phyllite ranging from about 2 inches to as much as 2 feet in diameter. The granodiorite clasts are similar in mineralogy and texture to the granodiorite west of Parmachenee Lake and probably were derived from that body. The matrix of the polymict metaconglomerate is dark-gray argillite.

\section{ARgILlAGEOUS METALIMESTONE UNIT}

The argillaceous metalimestone unit crops out in two small basins in the eastern and western parts of the Silurian outlier; these basins are separated from each other by the metaconglomerate and quartzite unit and are bounded on the south by the central east-trending fault. Excellent exposures of this unit are found on the north side of the unnamed brook near its entrance into Parmachenee Lake (pl. 1) and on the low hills east of the small swamp in the center of the outlier.

The argillaceous metalimestone is very fine grained, mottled light gray and white, and weathers to a rough, deeply grooved, light-rustbrown surface. Calcite and quartz veinlets a few tenths of a millimeter thick commonly form a meshwork pattern in the metalimestone. Fine- 
ly laminated argillaceous beds about 1 inch thick alternate with limestone layers of equal thickness producing a well-bedded rock. The argillaceous beds are relatively resistant and are visible as thin, rough ridges on the weathered surface. The beds have been warped into open folds that have subvertical axial surfaces parallel to the east-trending crudely developed cleavage in the rock. Adjacent to the northern fault, the bedding is obliterated by closely spaced shear planes that trend about N. $60^{\circ} \mathrm{E}$.

The argillaceous metalimestone is composed of very fine grained calcite and minor amounts of muscovite, quartz, and feldspar scattered throughout the rock and locally concentrated in the argillaceous beds.

\section{ARENAGEOUS METALIMESTONE UNIT}

Most of the arenaceous metalimestone member is in the eastern part of the outlier where it is the youngest unit in the doubly plunging syncline. It is locally well exposed on the low hills immediately east of the small swamp in the center of the outlier. A second, smaller patch is exposed in a small waterfall at an altitude of 1,670 feet in the small, unnamed brook that flows from the swamp in the center of the outlier to Parmachenee Lake.

The rock is green or gray green on the fresh surface and weathers to light gray or tan. It contains alternating beds of massive and pitweathering arenaceous metalimestone 2 to 15 inches thick. The pitweathering layers are commonly about 2 inches thick and, in the eastern part of the outlier, they are composed primarily of fragments of shelly fossils.

The bulk of the arenaceous metalimestone is composed of calcite, which is present as a granular matrix and as shell fragments. The calcite grains are anhedral and range in diameter from $20 \mu$ to $0.1 \mathrm{~mm}$; the coarser material comprises the shell fragments. Quartz, plagioclase, clinozoisite, zircon, tourmaline, and pyrite, are present in subordinate amounts. The quartz and plagioclase are angular to subangular.

The arenaceous metalimestone lies conformably and gradationally above the argillaceous metalimestone member. The contact zone in the eastern basin is about 5 feet thick and is composed of mixed layers of white to light-gray argillaceous metalimestone and arenaceous metalimestone a few inches thick.

\section{UNNAMED SILURIAN ROCKS}

Thin lenses of polymict metaconglomerate and a somewhat more continuous layer of calcareous slate and metalimestone, unnamed in this report, form the basal Silurian rocks on and near Thrasher Peaks 
(pl. 1) in the northwestern part of the Cupsuptic quadrangle and in the adjoining part of the Arnold Pond quadrangle.

The polymict metacong]omerate, which ranges in thickness from 0 to about 100 feet, contains no fossils but is assigned a Silurian age (late Llandovery to Ludlow) because of its lithologic similarity with metaconglomerate units in the Rangeley Formation and the metaconglomerate and quartzite unit near Parmachenee Lake. The calcareous slate is about 500 feet thick and contains lenses of metalimestone as much as 50 feet thick. This unit is tentatively assigned a Late Silurian (Ludlow?) age on the basis of fossils at locality S-4 (pl. 1), which were found and discussed by Green $(1968, p .1615)$. The calcareous slate and metalimestone unit is probably equivalent, in part, to the unnamed calcareous rocks east of Parmachenee Lake and to the Hardwood Mountain Formation (Boucot, 1961) found at the base of Silurian and Devonian rocks in scattered localities to the northeast.

The polymict metaconglomerate and the calcareous slate and metalimestone units are inferred to rest unconformably on the Magalloway Member of the Dixville. The unconformity was not seen, and bedding in the overlying and underlying rocks near the inferred unconformity is approximately parallel. The unconformable relationships are apparent on a regional scale, however, because Silurian and Devonian rocks truncate various members of the Dixville Formation on strike to the southwest (Green, 1968; Green and Guidotti, 1968).

\section{POLYMICT METACONGLOMERATE}

Polymict metaconglomerate is exposed in scattered outcrops at an altitude of 2,400 feet near the middle of the northwest slope of Thrasher Peaks (pl. 1). A second, smaller patch of polymict metaconglomerate is found at 2,260 feet altitude on the southeastern slope of Thrasher Peaks and, according to Green (1968), it extends about half a mile into the Second Lake quadrangle.

The metaconglomerate is dark green to purplish gray and is composed predominantly of clasts of greenstone similar to the greenstone in the Magalloway Member of the Dixville Formation. In addition to greenstone, the clasts include vein quartz, purplish-gray slate, feldspathic graywacke, and chert, ranging in size from 0.5 to 8 inches. The matrix is feldspathic metasandstone and, locally, gray metasiltstone composed predominantly of fine- to medium-grained quartz, chlorite, plagioclase, and muscovite. Bedding was not seen in the polymict metaconglomerate. 


\section{GALGAREOUS SLATE AND METALIMESTONE}

Calcareous slate containing lenses of dark- to light-gray, coarsely crystalline metalimestone and limestone edgewise metaconglomerate outline a small syncline of Silurian and Devonian rock in the southwestern part of the Arnold Pond quadrangle and the adjoining part of the Cupsuptic quadrangle. Outcrops are scarce, but both the slate and metalimestone are exposed due west of marker post 460 on the international boundary and in the First East Branch of the Magalloway River north of the road to Lower Black Pond (pl. 1). Elsewhere along the trend of the unit, the metalimestone forms scattered and relatively resistant outcrops that locally expose the calcareous slate at their margins.

The calcareous slate is dark gray, soft, weathers punky brown, and is not visibly bedded except for the lenses of limestone. Pyrite cubes are the only macroscopic mineral present in the slate, which is mainly composed of quartz, muscovite, chlorite, calcite, and albite.

The metalimestone is commonly conglomeratic and is made up of dark-gray, medium-grained, platy, metalimestone fragments as much as 12 inches long, surrounded and cemented by light-gray, coarsely crystalline metalimestone that locally contains more than 50 percent of recognizable crinoid fragments. Thin partings of gray calcareous slate are present in the metalimestone lenses.

The metalimestone is composed of more than 90 percent calcite and contains scattered grains of quartz, albite, and muscovite. The discontinuous nature of the limestone and the presence of edgewise conglomerate cemented by fossil fragments suggest that the patches of metalimestone were part of a reef that was partly and perhaps periodically broken down by wave action in a shallow-water, shelf environment.

\section{UNNAMED SILURIAN AND DEVONIAN ROCKS}

In the western part of the Arnold Pond quadrangle, metamorphosed felsic tuff, red slate, and interbedded green slate and metasiltstone form a sequence that lies conformably above the Upper Silurian calcareous slate and metalimestone unit (described earlier) and cenformably below the Lower Devonian Seboomook Formation (described in a later section). No fossils were found in these rocks, but they must be Late Silurian or Early Devonian in age, or both, because of their position in the stratigraphic sequence.

The contacts of these rocks are exposed on the ridge about 1,500 feet west of marker post 460 on the international boundary. Here, a layer of highly resistant metamorphosed felsic tuff rests conformably above the calcareous slate and metalimestone unit along a sharp contact that 
dips about $45^{\circ}$ west. The felsic metatuff is overlain by a lens of red slate also along a sharp conformable contact. The red slate lens, in turn, is conformably overlain by well-bedded gray slate and feldspathic quartzite of the Seboomook Formation along a gradational contact of mixed purplish-gray slate about 4 feet thick. The Seboomook Formation rests with apparent conformity on the metamorphosed felsic tuff where the red slate is missing.

West of Deer Brook (pl. 1), red slate containing thin bedz of felsic metatuff and gray metasiltstone rests directly on greenstone assigned to the Dixville Formation by Harwood (1969a). The contact between the red slate and the greenstone is sharp and is inferred to be an unconformity primarily from the differences in the ages assigned to the red slate and the underlying greenstone. This unconformity has not been unequivocally established, however, owing to the absence of fossils and distinct bedding in the greenstone at the contact of the overlying red slate. Green slate and metasiltstone overlie the red slate along a gradational zone of mixed red and green slate that is about 5 feet thick. The green slate and metasiltstone are in sharp contact with the greenstone where the red slate is missing.

The red slate and green slate and metasiltstone units are in the same stratigraphic position-below the Seboomook Formation, and interbedded with or above calcareous slate and metalimestone of Late Silurian age--as are the red slate-bearing Capens and Lobster Lake Formations (Boucot, 1961) in the Moose River synclinorium to the northeast. For this reason, the red slate and green slate and metasiltstone units are tentatively correlated with the Capens and Lobster Lake Formations and are of Late Silurian age.

\section{METAMORPHOSED FELSIG TUFF}

A layer of light-greenish-gray, white-weathering, hard, massive to finely laminated and flow-banded felsic metatuff 30 to 100 feet thick forms a pronounced break in slope above the calcareous slate and metalimestone unit west of marker post 460 on the international boundary. The metatuff also forms scattered but pronounced hogback outcrops along the trace of the unit shown on plate 1.

The felsic metatuff varies in appearance from a highly schistose yellowish-green rock that feels greasy to the touch to a mottled gray and light-green, very fine grained flow-banded rock that contains quartz and albite phenocrysts. In the banded metatuff, light-green schistose laminae a few millimeters thick, alternate with and outline light-gray, very fine grained, nonschistose feldspar-rich layers and lenticles a few millimeters to a few centimeters thick. 
The felsic metatuff is composed primarily of very fine grained, interlocking crystals of untwinned albite and quartz. These grains are outlined by anastomosing networks of white mica, probably muscovite, that are a few millimeters thick. The white mica content varies from about 90 percent in the schistose laminae to about 20 percent in the nonschistose laminae. Euhedral to rounded phenocrysts of twinned albite, generally less than $1 \mathrm{~mm}$ long, are set in the very fine grained matrix of albite, quartz, and mica. The phenocrysts make up about 3 percent of the rock.

\section{RED SLATE}

Maroon to brick-red slate containing thin beds of metasiltstone and metamorphosed light-gray felsite is well exposed in discontinuous layers west of marker post 460 on the international boundary, about 0.5 mile north of Abbie Pond and 0.5 mile south of Upper Black Pond (pl. 1). The red slate is not a resistant unit and is commonly exposed only as a thin veneer on top of the more resistant metavolcanic rocks. The red slate unit ranges in thickness from 0 to 200 feet.

Red slate composed of quartz, muscovite, chlorite, albite, hematite, zircon, and tourmaline makes up 85 to 90 percent of most exposures; metamorphosed siltstone and felsite make up the remainder.

The metasiltstone beds weather light purplish gray, are not disinctly graded, range in thickness from about 0.5 to 3 inches, and are widely scattered throughout the red slate unit. The metasiltstone is composed of the same minerals as the slate but contains a slightly higher proportion of quartz and albite. North of Abbie Pond, discontinuous and highly contorted beds of white-weathering, light-gray metamorphosed felsite, each bed as much as 6 inches thick, are present in the slate in addition to the metasiltstone. These metamorphosed felsite beds are similar in composition to the felsic metatuff described in the preceeding section, but they contain no recognizable primary volcanic structure.

\section{GREEN SLATE AND METASILTSTONE}

Green slate and gray, locally calcareous, metasiltstone that are interbedded in variable proportions conformably overlie the red slate unit north of Abbie Pond and are inferred to rest unconformably upon greenstone of the Dixville Formation where the red slate unit is missing. Typical exposures of the green slate and metasiltstone are found on the northwest-trending ridge between Abbie Pond and Upper Black Pond. The maximum thickness of the green slate and metasiltstone unit is about 3,000 feet.

Soft, very fine grained green slate that weathers chalky white makes up 20 to 80 percent of an exposure, and light-gray fine-grained meta- 
siltstone makes up the remainder. The cleavage surfaces of the slate commonly have a silver-gray sheen due to very fine grained muscovite. Both the slate and metasiltstone are composed of quartz, muscovite, chlorite, albite, and magnetite (?) ; quartz and untwinned albite form more than 70 percent of the metasiltstone. Calcite is present in the calcareous metasiltstone.

The metasiltstone beds range in thickness from about 1 inch to as much as 5 feet. The thicker beds are graded and locally crossbedded. The crossbeds are marked by dark-green, paper-thin, arcuate laminations relatively rich in chlorite. In many outcrops the green slate has been dragged into the metasiltstone or completely transposed through the thinner metasiltstone beds parallel to the pronounced northeasttrending axial-plane cleavage.

\section{ROCKS OF DEVONIAN AGE}

\section{SEBOOMOOK FORMATION}

Thin-bedded, dark-gray slate and feldspathic quartzite exposed in the western part of the Arnold Pond quadrangle and the northwest corner of the Cupsuptic quadrangle are assigned to the Seboomook Formation. This assignment is based on (1) lithologic similarity, (2) position in the stratigraphic sequence above calcareous slate and metalimestone of Late Silurian age, and (3) the proximity of these rocks to exposures of the Seboomook Formation northeast of the map area (Boucot and others, 1964; Marleau, 1968). The Seboomook Formation in the Moose River synclinorium northeast of the map area contains fossils of Early Devonian age (Boucot, 1961).

Beds of dark-gray slate 1 to 8 inches thick are interlayered with beds of fine-grained feldspathic quartzite 0.5 to 4 inches thick, resulting in a characteristically thin-bedded or cyclically bedded rock. The quartzite beds are distinctly graded and weather to light-gray layers in the darker slate.

The Seboomook overlies the lens of red slate and the felsic metatuff unit along a sharp and conformable contact west of marker post 460 on the international boundary. The contact between the Seboomook and the unnamed green slate and metasiltstone unit west of Deer Brook (pl. 1) was not observed, but the pattern of minor folds and primary top-sense determinations near this contact and the contact near the outlet to Lower Black Pond (pl. 1) indicate the Seboomook overlies the green slate and metasiltstone. The lithologic differences between the Seboomook and the green slate and metasiltstone unit are not profound, and the eastward thinning of the latter suggests that these rocks may be equiralent facies. The maximum thickness of the Seboomook Formation in this area is 3,000 feet. 


\section{INTRUSIVE IGNEOUS ROCKS}

The stratified rocks have been intruded by a variety of igneous rocks, including serpentinite, gabbro, granodiorite, intrusive felsite, and quartz monzonite. Although no radiogenic age determinations have been made on these intrusive rocks, relative ages for most of them can be determined from field evidence in the mapped area or can be inferred from lithologic correlation with dated rocks found elsewhere in northern New England.

The ultramafic rocks in the Cupsuptic quadrangle and the eastern part of the Arnold Pond quadrangle are Middle Ordovician or younger because they intrude the Dixville Formation, but they are pre-Devonian because they are intruded by or metamorphosed by Devonian quartz monzonite. Green (1968) considered the serpentinite bodies in the northwest part of the Arnold Pond quadrangle to be Devonian because he considered the rocks they intruded to be Devonian. Harwood (1969a) proposed that this belt of metasedimentary and metavolcanic rocks was part of the Dixville Formation and that the serpentinite bodies in it could thus be Ordovician and contemporaneous with the other ultramafic bodies in the northern Appalachians (Chidester, 1962). The granodiorite west of Parmachenee Lake (pl. 1) is also considered to be Middle or Late Ordovician because it intrudes the Dixville Formation and appears as boulders in the Silurian polymict metaconglomerate east of the lake. Two small bodies of altered granodiorite, one at Little Kennebago Lake and the other at Bottle Mountain, and a small body of gabbro about 1.7 miles west of Cupsuptic Pond (pl. 1) cannot be unequivocally dated from field relationships. Because the feldspars are altered to sericite and the primary mafic minerals, hornblende and biotite, are partly replaced by actinolite and chlorite, the small bodies of granodiorite and gabbro that intrude Ordovician rocks are tentatively considered to predate the Devonian regional metamorphism and are assigned a Middle or Late Ordovician age.

Although the large quartz monzonite and granodiorite stocks in the area intrude only pre-Silurian rocks, they are considered to be either Middle or Late Devonian, because they are similar in composition to the two-mica granites of Devonian age found in New Hampshire and Maine (Billings, 1956; Faul and others, 1963). These rocks are undeformed and are relatively unaltered and thus seem to postdate the regional folding and metamorphism that affected the Early Devonian metasedimentary rocks in the area. The small intrusive felsite bodies are clearly post-Early Devonian and are probably Middle or Late Devonian, because they intrude rocks as young as Early Devonian above the Taconic unconformity in the northwestern part of the map 
area. The granitic dikes mapped on plate 1 are considered to be Devonian because they are lithologically similar to the quartz monzonite in the stocks.

The only intrusive rocks known to postdate the large Devonian stocks are fine-grained lamprophyre dikes that have distinct chilled borders against the quartz monzonite half a mile north of Amold Pond and in the lower part of Massachusetts Bog Stream (pl. 1). The lamprophyre dikes are clearly post-Devonian and are tentatively correlated with the White Mountain Plutonic Series of Late Triassic or Early Jurassic age.

\section{ORDOVICIAN ULTRAMAFIC AND MAFIC ROCKS}

Serpentinite that contains scatttered layers of serpentinized pyroxenite, peridotite, and talc-carbonate rock forms all of, or the major part of, seven small plutons in the Cupsuptic and Arnold Pond quadrangles. Five of the serpentinite bodies occur in roof pendants in the Seven Ponds pluton near Arnold Pond (pl. 1); one body intrudes rocks of the Dixville Formation in the northwestern corner of the Arnold Pond quadrangle; and the largest pluton intrudes rocks of the Dixville on White Cap Mountain (pl. 1) in the northeastern part of the Cupsuptic quadrangle. The serpentinite bodies are tabular or elliptical in plan and range in width from 100 to 5,000 feet. The largest body is more than 4 miles long. All the plutons tend to be elongate parallel to the strike of the surrounding metamorphosed sedimentary and volcanic rocks. The layers of pyroxenite found in all the bodies and the talc-carbonate rock found only in the two largest bodies are scattered in the serpentinite and do not appear to be arranged in zones related to the walls of the plutons.

All the serpentinite and serpentinized ultramafic rocks are mapped as one unit because the different rock types are intermixed and generally occur as thin lenses too small to be shown at the scale of the map. The serpentinized ultramafic rocks are mapped separately from metadiorite in the White Cap Mountain intrusive body where large masses of these two rock types are interlayered. Metadiorite similar to that on White Cap Mountain also occurs as discontinuous patches in the serpentinite in the northwest corner of the Arnold Pond quadrangle, but these patches of metadiorite are too small to show separately.

Chlorite-magnetite rock and actinolite-magnetite rock typical of the blackwall zone of Chidester (1962) were found in two small outcrops at the contact of the serpentinite and the Magalloway Member of the Dixville Formation on the east slope of White Cap Mountain. In each outerop, serpentinite was the only ultramafic rock in the con- 
tact zone. The absence of more complete blackwall zoning is probably related to the lesser degree of steatization of these ultramafic bodies relative to those in Vermont described by Chidester (1962).

\section{SERPENTINITE}

The dark-green, massive to schistose serpentinite weathers whito to light tan and is intensely fractured and commonly crosscut by anastomosing shear planes that contain thin selvedges of magnetite and slip-fiber asbestos. Cross-fiber asbestos also occurs in veinlets less than 0.5 inch thick, but these veinlets are rare and widely scattered. Crossfiber and slip-fiber veinlets are most abundant in the serpentinite in the northwest corner of the Arnold Pond quadrangle where they make up less than 0.1 percent of the exposed rock. Locally, the serpentinite has a granular texture and grades into a rock containing grains of carbonate associated with minor amounts of talc. None of the bodies is visibly zoned and talc- carbonate rock and serpentinite are intermixed on an outcrop scale.

In thin section the serpentinite is mainly a felted aggregate of serpentine flakes containing minor amounts of carbonate, talc, and magnetite. Some of the serpentinite contains scattered grains of relict clinopyroxene and olivine that are deeply etched and replaced by very fine grained radiating aggregates of serpentine which is finer grained and has a different texture from that of the matrix. The presence of relict olivine associated with clinopyroxene in the pseudomorphic serpentinite indicates that peridotite was the protolith of some of the serpentinite. Representative estimated modes are given in table 3.

\section{PYROXENITE}

Several outcrops of rather fresh pyroxenite occur in a narrow band at an altitude of 2,500 feet on the north slope of the 2,720-foot hill east of the Kennebago River in the northeast corner of the Cupsuptic quadrangle and at scattered localities north and south of Arnold F'ond (pl. 1).

The pyroxenite is massive, medium to coarse grained, equigranular to pegmatitic, dark green to black where fresh and rusty gray or light $\tan$ where weathered. The rock is a very hard, dense aggregate of pyroxene grains, the cleavage faces of which reflect light on the fresh surface. All stages of alteration from granular pyroxenite containing thin veinlets of light-green serpentine to serpentinite pseudomorphically replacing large pyroxene crystals were observed.

The pyroxenite is composed of pale-green to colorless clinopyroxene which can be tentatively identified as magnesian augite from an estimated $2 \mathrm{~V}$ of $50^{\circ}$ and a measured $\beta$ refractive index of $1.685 \pm 0.003$. 
TABLw 3.-Representative estimated modes of the serpentinized ultramafic rocks and metadiorite from the Cupsuptic and Arnold Pond quadrangles, Maine

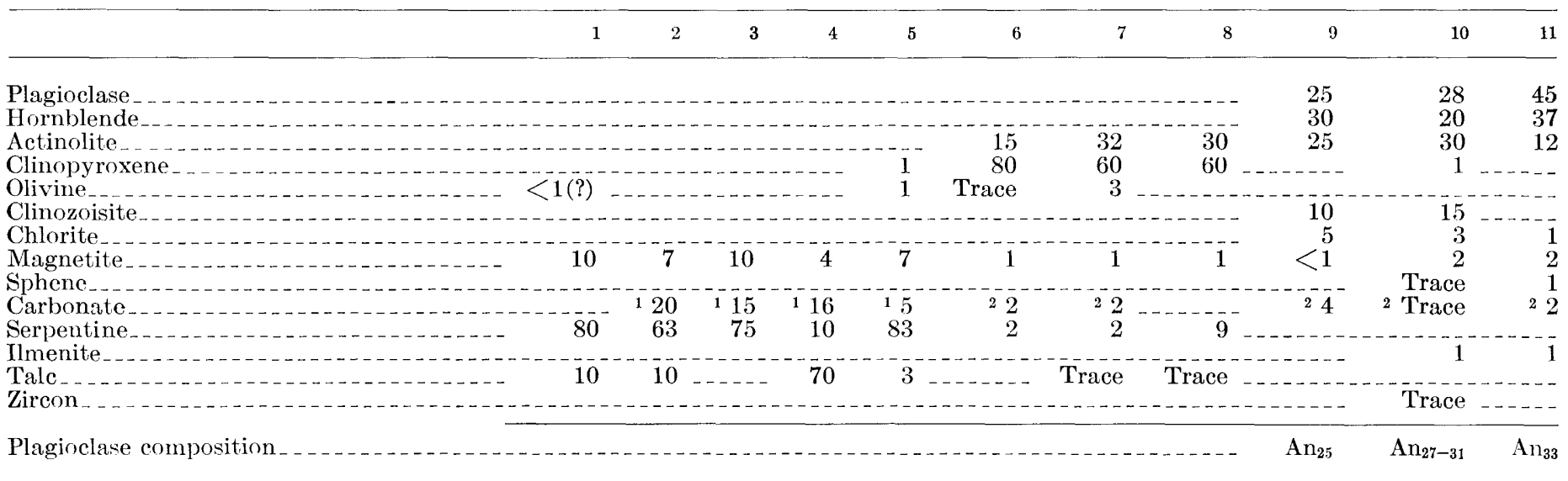

\section{Magnesite(?)}

Schistose serpentinite; on top of 2,720 -foot knob, 4,500 feet (bearing $106^{\circ}$ ) from the 1,950-foot bench mark on the Beaver Pond Tote Road.

at 2,380 feet altitude, 2,800 feet (bearing $217^{\circ}$ ) from

1,950 -

Sugary textured serpentinite; at 3,350 feet altitude, 1,500 feet (bearing $071^{\circ}$ ) from corner post 450 on the international boundary.

4. Talc-carbonate rock; at 3,340 foot altitude, 2,900 feet (bearing $015^{\circ}$ ) from 3,740 -foot north summit of Kennebago Divide.

. Prom 1 950-foot bench mark on Beaver Pond Tote Road.

7. Metapyroxenite; at 2,520 feet altitude, 900 feet due west of the location of sample 6 . Coarse-grained, serpentinized pyroxenite; at 2,400 feet altitude, 2,800 feet (bearing $217^{\circ}$ ) from 1,950-foot bench mark on Beaver Pond Tote Road, northeast slope

9. Coarse-grained metadiorite transitional(?) to pyroxenite; at 2,500 feet altitude, 3,100 feet (bearing $219^{\circ}$ ) from 1,950-foot bench mark on Beaver Pond Tote Road.

10. Fine-grained, porphyritic metadiorite; at 2,700 foet altitude, 3,700 feet (bearing

11. Coarse-grained metadiorite; at 2,800 feet altitude, 3,900 feet (bearing $219^{\circ}$ ) from 1,950-foot bench mark on Beaver Pond Tote Road. 
These optical properties are consistent with those of magnesian augite given by Hess (1949) and modified by Muir (1951). No exsolved pyroxene lamellae were seen in the clinopyroxene host. The grains range in size from about $0.5 \mathrm{~mm}$ to about $10.0 \mathrm{~mm}$, are subhedral, and are altered to actinolite at the rim. Dustlike magnetite particles, scattered in the pyroxene grains, tend to concentrate along microscopic shear zones in the crystals. Anhedral patches of calcite and banded veinlets of serpentine are present in the pyroxene matrix. Representative modes are given in table 3.

\section{METADIORITE}

In addition to serpentinite and serpentinized pyroxenite described above, the pluton at White Cap Mountain and, to a lesser extent, the one in the northwest corner of the Arnold Pond quadrangle are composed of a very distinctive metadiorite.

The metadiorite is dark green to mottled green and white and weathers to dark rusty brown or tan. It varies from a dense, finegrained porphyritic rock to a coarse-grained pegmatitic rock that has ophitic texture. There appears to be no systematic variation in grain size in the metadiorite with respect to the contact of the associated ultramafic rocks or the country rock. The pegmatitic variety is commonly found as lens-shaped bodies, irregular stringers, or dikes in the fine- or coarse-grained metadiorite.

The metadiorite is composed primarily of hornblende, plagioclase $\left(\mathrm{An}_{25-35}\right)$, actinolite, and clinozoisite and contains lesser amounts of chlorite, calcite, magnetite, sphene, ilmenite, and zırcon. In areas adjacent to bands of serpentinite or pyroxenite, the metadiorite contains minor amounts of clinopyroxene rimmed by hornblende. Except in the porphyritic variety, the plagioclase and hornblende are the same size, ranging from about $0.2 \mathrm{~mm}$ to as much as $3.0 \mathrm{~cm}$ in length. Ophitic texture is common and is recognizable in hand specimen and thin section. Hornblende encloses or partly surrounds anhedral grains of plagioclase and is commonly altered around the grain boundaries to fine-grained, bladed aggregates of actinolite. The plagioclase is generally altered to granular aggregates of clinozoisite, calcite, and sericite. Representative modes are given in table 3.

On the north slope of White Cap Mountain, layers of serpentinite and metadiorite 300 to 900 feet thick dip about $50^{\circ} \mathrm{S}$., and on the south side of the mountain the layers dip about $80^{\circ} \mathrm{S}$. Serpentinite is always the rock type in contact with the country rock. East of the Kennebago River where metadiorite is locally in contact with the country rocks, layers of metadiorite and serpentinite from 10 to 50 feet thick dip 
about $70^{\circ} \mathrm{S}$. Although all of the rocks are intensely altered, the metadiorite shows an increase in hornblende relative to plagioclase toward the serpentinite contact, and clinopyroxene rimmed by hornblende is locally present in the metadiorite near the contact. These relations suggest that the metadiorite and ultramafic rocks originated from the same magma and were differentiated by crystal settling. Whether this differentiation took place in situ or at some greater depth with the differentiates being transported upward as stiff crystal mushes, as suggested by Thayer (1963) for similar Alpine peridotite-gabbro complexes, cannot be unequivocally determined. The gradational contacts between the metadiorite and serpentinite and the lack of chaotic layering or mineral sequences suggest that the differentiated magma was not transported for any significant distance. The absence of a contact aureole around the White Cap Mountain body, on the other hand, argues for an anomalously low temperature of emplacement. It is believed, however, that any contact metamorphism related to the serpentinite-metadiorite complex could have been obliterated by the low-grade regional metamorphism and contact metamorphism related to the Acadian orogeny and that the complex was differentiated in situ.

\section{GABBRO}

A small body of gabbro, which intrudes the Middle Ordovician Dixville Formation, is exposed on the group of 3,100-foot knobs about 1.5 miles west of Cupsuptic Pond (pl. 1) in the north-central part of the Cupsuptic quadrangle.

The gabbro is dark green to gray, equigranular, nonfoliated, and weathers dark rusty brown. It is composed primarily of plagioclase $\left(\mathrm{An}_{35}\right)$, hornblende, actinolite, clinozoisite, and chlorite and contains minor amounts of sphene, ilmenite, magnetite, and calcite. The plagioclase grains are commonly altered to sericite and clinozoisite. Hornblende is surrounded or completely replaced by aggregates of actinolite, chlorite, ilmenite, and calcite. In thin section the hornblende and plagioclase have an ophitic texture. A representative mode is given in table 4 .

Although the age of the gabbro is uncertain, the rock is highly altered and the body lacks any visible contact aureole with the Dixville, which implies it probably was emplaced prior to the Acadian regional metamorphism of the area. It is thus considered to be Middle or Late Ordovician in age. 
TABLE 4.-Representative modes of Ordovician gabbro and granodiorite from the Cupsuptic quadrangle, Maine

[V=visual estimate; $p=$ point count (number of counts indicated)]

\begin{tabular}{|c|c|c|c|c|c|}
\hline & 1 & 2 & 3 & 4 & 5 \\
\hline Quartz_ & & 40.0 & 34.4 & 20 & 18. 4 \\
\hline Alkali feldspa & & 31.6 & 35.5 & 13 & 32. 2 \\
\hline Plagioclase_.... & 45 & 19.5 & 23.4 & 40 & 32. 7 \\
\hline Biotite $_{-}$ & $\ldots$ & 4. 3 & & 10 & 7. 6 \\
\hline Sericite. & $\ldots$ & 3. 6 & 3.7 & Trace & .9 \\
\hline Hornblende.. & 25 & .4 & .5 & 6 & 1. 3 \\
\hline Chlorite..... & 5 & .3 & .9 & 1 & 2. 5 \\
\hline Clinozoisite........... & 10 & & & 7 & 2. 0 \\
\hline Zircon_........ & $\ldots$ & Trace & Trace & Trace & Trace \\
\hline Apatite & $\ldots$ & .2 & $\ldots \ldots$ & Trace & Trace \\
\hline Calcite.. & & & & & 1. 6 \\
\hline Ilmenite_-_- & Trace & & & 2 & .5 \\
\hline Magnetite. . & 1 & Trace & & & \\
\hline Limonite & & $-\ldots-1--$ & 1.8 & 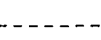 & $\ldots$ \\
\hline $\begin{array}{l}\text { Actinolite } \ldots \ldots \\
\text { Sphene }\end{array}$ & $\begin{array}{r}12 \\
2\end{array}$ & & & & --- \\
\hline Plagioclase composition. & $\mathrm{An}_{30}$ & $\mathrm{An}_{15}$ & $\mathrm{An}_{20}$ & $\mathrm{An}_{10}$ & $\mathrm{An}_{12}$ \\
\hline Method of analysis_... & V & $p=1,514$ & $\mathrm{p}=1,505$ & $\mathrm{~V}$ & $\mathrm{p}=1,256$ \\
\hline
\end{tabular}

1. Dark-gray, fine-grained gabbro; top of 3,100 -foot knob, 4,200 feet (bearing $227^{\circ}$ ) from 3,012 -foot bench mark on international boundary northwest of Cupsuptic Pond.

2. Dark-gray, highly fractured and sheared granodiorite; on small 2,080-foot knob, 3,700 feet (bearing $301^{\circ}$ ) from Otter Brook Camp.

3. Dark-to light-gray, intensely sheared and fractured granodiorite; on top of 2,300-foot knob east of Little Kennebago Lake.

4. Dark-gray, ophitic granodiorite; at 2,000 feet altitude, 2,300 feet (bearing $296^{\circ}$ ) from Otter Brook Camp.

5. Dark-gray, fine-grained porphyritic granodiorite; at 2,820 feet altitude, 400 feet due south of summit of Bottle Mountain.

\section{GRANODIORITE}

Granodiorite of Middle or Late Ordovician age forms three small, widely separated intrusive bodies. One is well exposed east and west of Little Kennebago Lake; a second is exposed on the low hills west of Parmachenee Lake; and a third, smaller body, is exposed near the top of Bottle Mountain in the Cupsuptic quadrangle (pl. 1).

The rock is medium grained, equigranular to subporphyritic, dark green or gray, and weathers dark rusty brown. White plagioclase phenocrysts fleck the dark-green matrix of the subporphyritic rock. The rock is highly fractured and is commonly laced with veins of white quartz or light-yellow-green veinlets of quartz, epidote, and calcite.

The bulk of the rock is composed of plagioclase $\left(\mathrm{An}_{10-20}\right)$, alkali feldspar, quartz, biotite, hornblende, chlorite, epidote, calcite, and minor amounts of zircon, ilmenite, pyrite, and apatite. Representative modes are given in table 4 . The plagioclase grains are concentrically zoned, subhedral laths as much as $2.0 \mathrm{~mm}$. long that are commonly altered to calcite, epidote, and sericite. The alkali feldspar is untwinned orthoclase containing broad lamellae of albite. Quartz and alkali feld- 
spar are anhedral and intergranular to the plagioclase. Biotite and hornblende form anhedral to subhedral grains that are commonly altered to chlorite, ilmenite, epidote, and calcite.

Granodiorite exposed near the major fault east of Little Kennebago Lake is medium grained, dark gray where fresh, and dark rusty brown where weathered. It is highly sheared and contains thin solution channels and vugs that are lined with euhedral quartz crystals as much as 0.5 inch long. Irregular patches and northeast-trending layers of milky white vein quartz as much as 4 feet thick are common. Hornblende, ubiquitous in the rock at other localities, is rarely present in rocks of the fault zone. Plagioclase is highly altered to sericite, calcite, and clinozoisite; biotite is altered to chlorite and ilmenite. Untwinned alkali feldspar is commonly present as a graphic intergrowth with quartz. All the mineral grains are fractured; quartz grains contain strain lamellae, and incipient mortar structure is present.

The granodiorite intrudes the Dixville Formation and is thus Middle Ordovician or younger. The composition and degree of alteration suggest that it is pre-Devonian and probably related to the Middle and Upper Ordovician Highlandcroft Plutonic Series in New Hampshire.

\section{DEVONIAN INTRUSIVE ROGKS}

Three rather large plutons, several smaller bodies, and numerous dikes ranging in composition from quartz monzonite to granodiorite intrude the stratified rocks of the map area. The largest pluton, named herein the Seven Ponds pluton (pl. 1), underlies most of the eastern part of the Armold Pond quadrangle and extends about 4 miles eastward into the Chain Lakes quadrangle. The Seven Ponds pluton is continuous with the Spider Lake Granite mapped by Marleau (1968) in the Woburn area (fig. 1). The Cupsuptic and Lincoln Pond plutons (pl. 1) of quartz monzonite composition are in the central and southwestern part of the Cupsuptic quadrangle, respectively. Several elongate bodies of intrusive felsite, ranging in composition from quartz monzonite to granite, intrude rocks above and below the Taconic unconformity in the western part of the Arnold Pond quadrangle and the adjacent part of the Cupsuptic quadrangle. Numerous granite dikes, which range in width from a few feet to a few tens of feet and have a consistent northeast trend, intrude parts of the Dixville Formation and the Albee Formation near the Cupsuptic pluton and on Deer Mountain (pl. 1). One sill of granodiorite intrudes the Rangeley Formation northeast of Johns Pond (pl. 1).

The quartz monzonite of the Cupsuptic and Lincoln Pond plutons is composed of approximately equal amounts of quartz, plagioclase, and microcline perthite and subordinate amounts of biotite and mus- 
covite. There are no major variations in the mineralogy of these two bodies and most of the surrounding dikes appear to be satellitic bodies of similar composition. The Seven Ponds pluton, on the other hand, is made up of an outer belt of quartz monzonite that contains biotite and muscovite near the contacts with the country rocks and biotite and minor amounts of hornblende elsewhere. The biotite-hornblende quartz monzonite of the Seven Ponds pluton changes gradually, with an increase in the amount of hornblende, to a hornblende-biotite granodiorite.

\section{QUARTZ MONZONITE}

The quartz monzonite is a medium- to coarse-grained, equigranular to subporphyritic light-gray rock flecked with black biotite. Near the country rocks in the Seven Ponds pluton, the rock is also flecked with pink alkali feldspar. The Lincoln Pond and Cupsuptic plutons have a discontinuous chilled border of dark-gray, fine-grained porphyry, 1 to 10 feet thick, which contains phenocrysts of plagioclase, quartz, and biotite. This porphyry and, to a lesser extent, white aplite occur as dikes and stringers within the Cupsuptic pluton. All three rock types, the quartz monzonite, porphyry, and aplite, are well exposed at the 1,745foot bench mark on the Cupsuptic Tote Road 1,500 feet south of Riverside Camp (pl. 1). The quartz monzonite is generally not foliated except near the narrow roof pendants of country rock in the Seven Ponds pluton and in the contact porphyry facies of the Cupsuptic and Lincoln Pond plutons.

The contact between the intrusive bodies and the contact-metamorphosed slate of the Dixville and Albee Formations in the Cupsuptic quadrangle is vertical or dips steeply outward from the intrusive body and is extremely sharp. The contact of the Cupsuptic pluton is exposed on the east slope of Cupsuptic Mountain and along the ridgecrest of Burnt Mountain (pl. 1). The country rocks along this contact are remarkably free of small dikes and pegmatites. In contrast to this, the contact between the Seven Ponds pluton and the Magalloway Member of the Dixville Formation is generally diffuse and is laced with numerous dikes, veinlets, and pegmatites. The pegmatites and many of the dikes contain salmon-pink alkali feldspar, quartz, scaly muscovite, minor amounts of biotite, and magnetite, or magnetite and hematite. A veinlet of specularite and pink alkali feldspar, about 2 feet long, was found in the country rock at the quartz monzonite contact on the ridge 5,000 feet north of the outlet of Northwest Pond (pl. 1).

Representative modes of the quartz monzonite are given in table 5. These rocks are not noticeably altered in hand specimen, but in thin section, chlorite and ilmenite replace scattered biotite flakes and chlo- 
rite and epidote replace some of the hornblende. All the quartz monzonite contains small amounts of apatite, zircon, and magnetite; the muscovite-bearing variety locally contains a trace of garnet and hematite, and the hornblende-bearing variety contains small amounts of sphene and allanite. The plagioclase grains have strong oscillatory zoning and range in composition from $A_{3} n_{3-45}$ at the core to $A_{15-25}$ near the edge. Some grains have resorbed cores. Microcline perthite is anhedral and, with quartz and biotite, fills the interstices between the plagioclase. Biotite is dark brown or reddish brown where it is associated with muscovite and is greenish brown to green where it is associated with hornblende. Quartz grains commonly contain rutile needles.

\section{GRANODIORITE}

The granodiorite can be distinguished from the quartz monzonite described above by its finer grain size, pronounced foliation, and greater abundance of hornblende and sphene. In the Seven Ponds pluton, the two rock types are gradational over a zone several hundred feet wide in which the rock is of intermediate grain size and contains as much as 2 percent hornblende. The contact between the granodiorite and quartz monzonite is drawn to separate the fine-grained, foliated granodiorite that contains 3 to 6 percent hornblende from this transition rock.

The granodiorite is less resistant than the quartz monzonite and forms a topographic basin containing several small ponds, bogs, and swamps. Excellent exposures are found at the southeast end of Crosby Pond and in the stream between Horseshoe Pond and Mud Pond (pl. 1).

The granodiorite is gray, fine to medium grained, locally porphyritic and strongly foliated. Hornblende and plagioclase phenocrysts as much as 0.5 inch long are alined in the plane of the foliation which is primarily produced by oriented plates of biotite. The foliation is essentially vertical and conformable with the quartz monzonite contact. Locally, hornblende phenocrysts define a lineation that plunges about $35^{\circ} \mathrm{N}$. Most pavement outcrops of the granodiorite are crossed by a characteristic network of joints, along the edges of which the rock is relatively enriched in quartz. The joints form rectangular or rhombohedral patterns of resistant ridges on the weathered surface of the rock. Along the edges of the joints, biotite and hornblende are partly altered to chlorite and epidote, and the alkali feldspar may be salmon pink. 
TABLE 5.-Representative modes of Devonian intrusive rocks from the Cupsuptic and Arnold Pond quadrangles, Maine

[V =visual estimate; $p=$ point count (number of counts indicated)]

\begin{tabular}{|c|c|c|c|c|c|c|c|c|c|c|c|c|c|c|}
\hline & 1 & 2 & 3 & 4 & 5 & 6 & 7 & 8 & 9 & 10 & 11 & 12 & 13 & 14 \\
\hline $\begin{array}{l}\text { Quartz } \\
\text { Microcline } \\
\text { Plagioclase } \\
\text { Biotite } \\
\text { Muscovite.... }\end{array}$ & $\begin{array}{r}40 \\
33 \\
18 \\
6 \\
2\end{array}$ & $\begin{array}{r}38.4 \\
22.0 \\
27.3 \\
.1 \\
3.1\end{array}$ & $\begin{array}{r}38 \\
43 \\
17 \\
\text { Trace } \\
2\end{array}$ & $\begin{array}{r}36.2 \\
22.2 \\
28.9 \\
6.5 \\
5.8\end{array}$ & $\begin{array}{r}34.4 \\
9.2 \\
39.9 \\
12.6 \\
2.0\end{array}$ & $\begin{array}{r}32.2 \\
16.6 \\
36.6 \\
9.4 \\
3.6\end{array}$ & $\begin{array}{r}32.0 \\
7.4 \\
28.8 \\
19.7 \\
10.1\end{array}$ & $\begin{array}{r}31.8 \\
3.4 \\
46.5 \\
16.1\end{array}$ & $\begin{array}{r}30.6 \\
9.0 \\
41.1 \\
17.4 \\
1.7\end{array}$ & $\begin{array}{r}30.3 \\
6.5 \\
43.2 \\
17.9 \\
1.6\end{array}$ & $\begin{array}{l}27.2 \\
13.1 \\
40.5 \\
13.1\end{array}$ & $\begin{array}{l}23.1 \\
11.1 \\
36.9 \\
26.5\end{array}$ & $\begin{array}{r}22.1 \\
3.4 \\
48.2 \\
21.8\end{array}$ & $\begin{array}{r}17.6 \\
13.2 \\
55.5 \\
9.6 \\
3.4\end{array}$ \\
\hline $\begin{array}{l}\text { Hornblende } \\
\text { Garnet }\end{array}$ & Trace & & & & & & $10.1-$ & .4 & & & 3.1 & .8 & 1.5 & \\
\hline $\begin{array}{l}\text { Clinozoisite } \\
\text { Chlorite } \\
\text { Zircon } \\
\text { Apatite } \\
\text { Calcite }\end{array}$ & $\begin{array}{l}1 \\
\text { Trace } \\
\text { Trace }\end{array}$ & $\begin{array}{c}6.4 \\
\text { Trace } \\
-2.3\end{array}$ & $\begin{array}{l}\text { Trace } \\
\text { Trace } \\
\text { Trace }\end{array}$ & $\begin{array}{l}\text { Trace } \\
\text { Trace }\end{array}$ & $\begin{array}{l}\text { Trace } \\
\text { Trace } \\
\text { Trace } \\
\text { Trace }\end{array}$ & $\begin{array}{r}\text { Trace } \\
\text { Trace } \\
\text { Trace }\end{array}$ & $\begin{array}{l}\text { Trace } \\
\text { Trace } \\
\text { Trace } \\
\text { Trace }\end{array}$ & $\begin{array}{r}.2 \\
1 \\
1 \\
\text { Trace }\end{array}$ & $\begin{array}{l}\text { Trace } \\
\text { Trace } \\
\text { Trace }\end{array}$ & $\begin{array}{l}\text { Trace } \\
\text { Trace } \\
\text { Trace } \\
\text { Trace }\end{array}$ & $\begin{array}{r}\text { Trace } \\
\text { Trace } \\
.1\end{array}$ & $\begin{array}{r}.8 \\
\text { Trace } \\
.1\end{array}$ & $\begin{array}{r}\text { Trace } \\
\text { Trace } \\
.2\end{array}$ & $\begin{array}{r}\text { Trace } \\
1 \\
\text { Trace } \\
\text { Trace }\end{array}$ \\
\hline $\begin{array}{l}\text { Calcite } \\
\text { Sphene.e. } \\
\text { Allanite..... }\end{array}$ & $\cdots$ & 2.3 & - & -1 & -- & ......... & $\cdots$ & Trace & 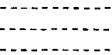 & -.. & .7 & .8 & $\begin{array}{r}1.5 \\
.2\end{array}$ & Trace \\
\hline $\begin{array}{l}\text { Pyrite } \\
\text { Magnetite... } \\
\text { Hematite. }\end{array}$ & Trace & Trace & & Trace & Trace & Trace & Trace & Trace & Trace & $\begin{array}{l}\text { Trace } \\
\text { Trace }\end{array}$ & Trace & 1 & .2 & $\begin{array}{l}\text { Trace } \\
\text { Trace }\end{array}$ \\
\hline $\begin{array}{l}\text { Ilmenite } \\
\text { Myrmekite........ }\end{array}$ & Trace & Trace & & -.... & 1.2 & Trace & - n & 0.4 & & Trace & 1.7 & .1 & .2 & .4 \\
\hline Plagioclase composition.- & $A n_{10}$ & $\mathrm{An}_{10}$ & $\mathrm{An}_{15}$ & $A n_{15-25}$ & $\mathrm{An}_{15-30}$ & $\mathrm{An}_{19-22}$ & $\mathrm{An}_{20}$ & $\mathbf{A n}_{23}$ & $\mathrm{An}_{20}$ & $A n_{10-35}$ & $\mathrm{An}_{15-25}$ & $\mathrm{An}_{20-28}$ & $\mathrm{An}_{25-35}$ & $\overline{\operatorname{An}_{15-20}}$ \\
\hline Method of analysis. - & $\mathrm{V}$ & $\mathrm{p}=1,214$ & $\mathrm{~V}$ & $\mathrm{p}=1,534$ & $\mathrm{p}=1,602$ & $\mathrm{p}=1,541$ & $p=1,018$ & $\mathrm{p}=1,464$ & $\mathrm{p}=1,150$ & $p=1,536$ & $p=1,361$ & $p=1,184$ & $p=1,233$ & $\mathrm{p}=1,481$ \\
\hline
\end{tabular}

1. Coarse-grained, porphyritic biotite-muscovite quartz monzonite; at 2,440 feet altitude, 2,500 feet (bearing $075^{\circ}$ ) from 1,950-foot bench mark on Beaver Pond

2. Dark-gray, medium-grained, porphyritic granodiorite; on top of 2,408 -foot knob (shown as 2,308 feet on map), 4,800 feet due south of Grants Camp cn Kennebag?

White, very fine grained intrusive felsite; at top of 2,540-foot knob that is the northernmost summit of Thrasher Peaks, approximately on northern border of

4. Medium-grained, equigranular, biotite-muscovite quartz monzonite; at 2,960 feet altitude, 4,500 feet (bearing $044^{\circ}$ ) from summit of Bull Mountain.

5. Coarse- to medium-grained bic tite-muscovite quartz monzonite; at 3,705 feet alti(1)

6. Medium- to coarse-grained, biotite-muscovit 3 quartz monzonite; at 3,340 feet altitude, on south side of 3,360 -foot $\mathrm{knob}, 4,100$ feet (bearing $250^{\circ}$ ) from the western peak of Twin Mountains.

7. Fine-grained biotite-muscovite quartz monzonite; at 1,860 feet altitude, 4,100 feet (bearing $077^{\circ}$ ) from Nasons Camp on east shor ${ }^{2}$ of Aziscohos Lake.

8. Coarse-grained quartz monzonite; at top of 2,360-foot knob, 2,500 feet northwest

9. Dark tet to facies; 1060 feet altitude 2,300 feet (bearing $197^{\circ}$ ) from 2,217 foot summit of $B$ ig Buck Mountain.

10. Fine- to medium-grained, porphyritic biotite-muscovite quartz monzonite; dike on the west side of Cupsuptic Mountain; at 2,420 feet altitude, 900 feet (bearing

$\left.246^{\circ}\right)$ from 2,640 foot summit of Cupsuptic Mountain.
11. Biotite-hornblende granodiorite; on 1,540 foot knob, 3,500 feet north of Mud Pond.

12. Crudely foliated quartz monzonite, at 2,300 feet altitude, 1.4 miles (bearing $100^{\circ}$ ) from south end of Massachusetts Bog.

13. Biotite-hornblende quartz monzonite, on 1,940 foot knob, 0.9 mile (bearing $095^{\circ}$ ) from outlet to Massachusetts Bog.

14. Biotite-muscovite quartz monzonite; at 2,260 feet altitude, 0.7 mile north of Northwest Pond. 
Plagioclase forms the largest grains in the rock and a single phenocryst may contain two or three partly resorbed cores that are surrounded, or partly surrounded, by subsequent zones. Microcline perthite is anhedral and intergranular to the plagioclase. Fine-grained granular quartz contains rutile and is commonly intergrown with alkali feldspar and biotite. Biotite is dark greenish brown and contains anhedral crystals of sphene along its grain boundaries. Hornblende is dark green, anhedral to euhedral, and commonly twinned parallel to (110). No exsolution lamellae were seen in the hornblende. In addition to microscopic sphene formed at the edges of biotite, the rock contains euhedral crystals of sphene as much as $3 \mathrm{~mm}$ long. The feldspars are locally sericitized, and biotite and hornblende are partly altered to chlorite and epidote. The rock is not as altered as the Ordovician granodiorite described in a preceding section. Representative modes are given in table 5 .

\section{INTRUSIVE FELSITE}

Several small bodies of intrusive felsite are exposed in the northwest corner of the Cupsuptic quadrangle and in the western part of the Arnold Pond quadrangle. The rock is rather resistant and commonly forms precipitous ledges or pronounced hogback ridges. Large exposures are found at the southwest end of Thrasher Peaks and along the banks of the Second East Branch of the Magalloway River between Upper and Lower Black Ponds (pl. 1).

The rock is extremely fine grained, equigranular, massive, white to light gray where fresh, and white to light $\tan$ where weathered. It is very hard, has a chertlike appearance, and commonly breaks with conchoidal fractures to produce sharp-edged talus. Quartz veinlets a few millimeters wide cross cut the rock in most ontcrops.

The bulk of the rock is composed of microscopic quartz, orthoclaseperthite, plagioclase $\left(\mathrm{An}_{25}\right)$, and biotite, it also contains lesser amounts of muscovite, zircon, and pyrite. Unzoned plagioclase grains as much as $0.1 \mathrm{~mm}$ long are commonly surrounded by anhedral aggregates of quartz and perthite. Biotite flakes and lesser amounts of ragged anhedral muscovite grains are intergranular to the quartz and feldspar. A representative mode is given in table 5 .

\section{POST-DEVONIAN INTRUSIVE ROCKS}

\section{LAMPROPHYRE DIKES}

Four unmetamorphosed lamprophyre dikes are known to intrude the metasedimentary rocks and the quartz monzonite in the northeastern part of the map area. The best exposure is at an altitude of 1,460 feet in Massachusetts Bog Stream (pl. 1) where a 2-foot-thick 
dike clearly forms a chilled border against the quartz monzonite of Devonian age. The other dikes range in thickness from 2 to 8 feet. These dikes, like those in northern New Hampshire reported by Billings $(1956$, p. 86$)$ and Hatch $(1963$, p. 49), are probably related to the White Mountain Plutonic Series (Billings, 1956) of Late Triassic or Early Jurassic age.

The rock is commonly aphanitic except in the center of the larger dikes, where it has an ophitic texture. White, spherical amygdules of calcite are present and weather out to form a pitted surface. The rock is black to dark green on the fresh surface and weathers to a soft, punky, rusty brown rind that commonly spalls off in spheroidal shells.

Thin section studies of the rock most commonly reveal a distinct ophitic texture in which randomly oriented laths of brown basaltic hornblende and colorless augite surround interstitial masses of plagioclase; less commonly the relationships are reversed, giving a diabasic texture. The bulk mineralogy of all the lamprophyre dike rocks is very similar and consists primarily of plagioclase, augite, basaltic hornblende, calcite, chlorite or biotite (or both), magnetite, ilmenite, and rutile. Plagioclase is present in amounts roughly equal to augite and basaltic hornblende combined and makes up about 50 percent of the rock. Augite, the most common ferromagnesian mineral, occurs as stubby laths or rather large subhedral phenocrysts and forms 20 to 45 percent of the rock. Basaltic hornblende, strongly pleochroic from red brown to pale yellow brown, makes up as much as 25 percent of the rock. Calcite in the rounded amygdules contains scaly plates and radiating fibrous masses of chlorite or biotite, or both. Locally the amygdules also contain very fine grained, untwinned feldspar. Microphenocrysts of magnetite and ilmenite make up as much as 2 percent of the rock.

The mineralogy of the dikes indicates that they are most closely akin to the spessartite-camptonite rocks described in Williams, Turner, and Gilbert $(1954$, p. $88-89)$.

\section{METAMORPHISM}

\section{REGIONAL METAMORPHISM}

All the stratified rocks in the Cupsuptic and Arnold Pond quadrangles have undergone regional metamorphism to chlorite grade. Mineral assemblages with quartz and muscovite include chlorite and albite with or without magnetite, hematite, pyrite, zircon, and tourmaline in argillaceous rocks of the Albee and Dixville Formations and chlorite-plagioclase-detrital potassium feldspar, magnetite, zircon, and tourmaline in the Magalloway Member of the Dixville Formation. 
The mafic volcanic rocks in the Dixville and Albee Formations are actinolitic greenstones composed of actinolite, sodic plagioclase, chlorite, quartz, epidote, magnetite, and calcite. The greenstones show no variation in their mineral assemblages throughout the area of regional metamorphism. The assemblages are typical of the greenschist facies of Turner and Verhoogan (1960).

The degree of recrystallization associated with the regional metamorphism increases southwestward across the Cupsuptic quadrangle. This is indicated by (1) a gradual increase in the grain size of chlorite, muscovite, and magnetite, (2) an increase in the amount of quartz pods and stringers in the Albee Formation, and (3) a progressive change in the foliation from a slaty cleavage on the east to schistosity in the southwest. In spite of these textural changes, the rocks contain no stilpnomelane or biotite. Locally, in the southwestern part of the Cupsuptic quadrange, the rocks contain quartz-spessartite stringers referred to as coticule horizons by Emerson (1898, p. 174) and Clifford (1960). Apparently the rocks never reached the field of biotite stability, or biotite would be present in the arenaceous beds in the Albee Formation as it is in the outer margins of the contact aureoles described later. The absence of stilpnomelane, on the other hand, is probably due to the relative abundance of magnesium over iron in the Albee Formation, as indicated by the abundance of cordierite instead of staurolite or garnet in the contact aureoles.

Magnetite is ubiquitous in the green slate and phyllite of the Albee Formation, and hematite or, locally, hematite and magnetite are present in the purple slate. The sporadic occurrence of hematite- and magnetite-rich slate and the presence of both oxides in several areas well removed from the contact aureoles indicates the progressive increase in regional metamorphism was not accompanied by a progressive oxidation or reduction in this area.

\section{CONTACT METAMORPHISM}

'I'he rocks adjacent to the quartz monzonite plutons have been contact metamorphosed to aureoles of highly resistant hornfels approximately conformable with the shapes of the intrusive bodies. Three isograds that mark the first appearance of biotite, andalusite, and sillimanite, respectively, have been mapped around the Seven Ponds and Cupsuptic plutons. Around the Lincoln Pond pluton, however, only the andalusite isograd has been mapped because of the narrowness of the contact aureole and the scarcity of exposures in its outer margins. In the southeastern part of the Cupsuptic quadrangle, the rocks have been contact metamorphosed to biotite grade and probably to andalusite grade around the west end of a gabbro body east of the map area. 


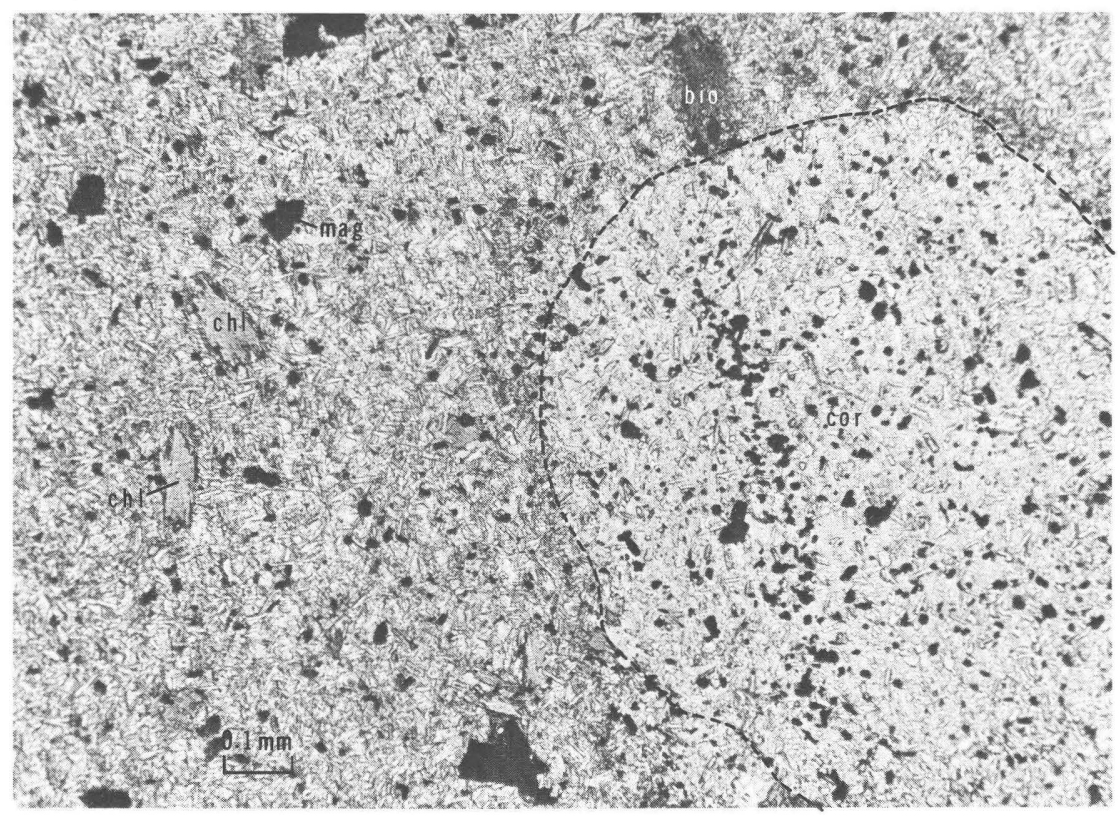

FIGURE 7 (above and right).-Photomicrographs of contact-metamorphosed rocks of the Albee Formation in the contact aureole of the Cupsuptic pluton. Above: maculose hornfels from the biotite zone. Lighter gray, rounded porphyroblast of cordierite in lower right of photograph set in very fine grained matrix of muscovite, quartz, and albite. Plane-polarized light. From west slope of Cupsuptic Mountain. Right: fibrous mat of sillimanite (sil) replacing biotite. Gray patches in fibrous mat are remnant biotite flakes. Plane-polarized light. From south slope of Burnt Mountain. bio, biotite; chl, chlorite; cor, cordierite; mus, muscovite; mag, magnetite; qtz, quartz.

Abundant float of andalusite hornfels occurs on the east slope of Ephraim Ridge (pl. 1), but there is not enough outcrop to locate the andalusite isograd.

Biotite first appears in quartzite beds and adjacent to quartz pods in the Albee Formation and has a rather wide distribution in the contact-metamorphosed graywacke of the Magalloway Member of the Dixville Formation; its first appearance under appropriate conditions is in the less aluminous rocks. The argillaceous rocks in the biotite zone are spotted slates or maculose hornfels in which the regional foliation is well preserved. Common mineral assemblages, with quartz and muscovite, in the biotite zone are biotite-chlorite-albite, biotitechlorite-cordierite-albite (fig. 7), and biotite-microcline-albite \pm chlorite. Very fine grained manganiferous garnet or epidote locally appears in these assemblages. 


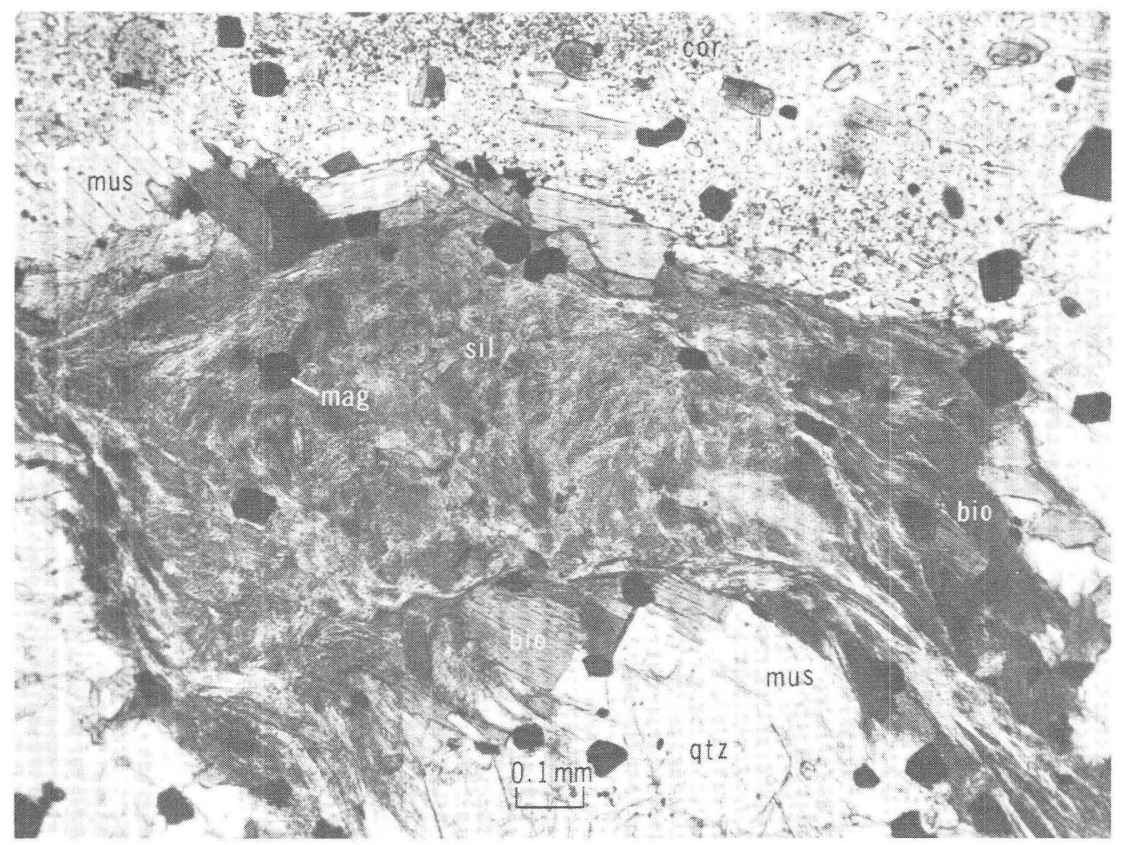

Andalusite appears first as poikiloblastic anhedral grains in the argillaceous rocks and persists into the sillimanite zone where it forms lath-shaped porphyroblasts as much as $3 \mathrm{~cm}$ long. With the appearance of andalusite, the rock is more completely recrystallized than in the biotite zone, but the regional foliation is still recognizable. Quartz, muscovite, and sodic plagioclase are ubiquitous, and, in the andalusite zone, the common mineral assemblages include andalusite-biotite-chlorite, andalusite-biotite-cordierite, and andalusite-biotite-chlorite-cordierite. Manganiferous garnet is present in addition to the above minerals in some of the rocks. Staurolite associated with andalusite and biotite, or chlorite and biotite, was found in three thin sections from the aureole around the Lincoln Pond pluton (pl.1).

Argillaceous rocks in the sillimanite zone are equigranular or medium-grained porphyroblastic hornfels in which the regional foliation has been completely obliterated. Sillimanite is not readily visible in hand specimen, but the marked change in the texture of the rock and the presence of coarse spangles of muscovite serve as field guides to recognizing the sillimanite-grade rocks. Mineral assemblages with quartz, muscovite, and sodic plagioclase are sillimanite-biotite-cordierite and sillimanite-biotite-garnet. Locally, adjacent to the Cupsuptic pluton and commonly in the roof pendants near Arnold Pond (pl. 1), 
muscovite is partly replaced by the fibrolite variety of sillimanite and orthoclase or microcline. As shown in figure 7, biotite is also replaced by fibrolite and magnetite. The breakdown of the hydrous minerals is apparently the result of the low activity of water in the inner part of the aureole rather than of their thermal instability, because both biotite and muscovite are stable in the quartz monzonite. A detailed study of the delta index of cordierite around the Cupsuptic pluton (Harwood, 1969b) also suggests a lower activity of water in the inner part of the contact aureole.

The breakdown of the hydrous minerals and the fresh appearance of cordierite and feldspar in the sillimanite zone seem to indicate that there was very little movement of fluids from the intrusive rocks into the hornfels during contact metamorphism. Retrograde metamorphism in the inner part of the aureoles is shown only locally by chlorite and ilmenite that have replaced biotite. In the outer part of the aureoles, however, cordierite is replaced completely or partly by white mica and chlorite, and the feldspars in the Magalloway Member are almost completely replaced by white mica. These textures suggest that the aureoles acted as relatively anhydrous sinks in the late stages of metamorphism and were retrograded inward to the limit of permeability.

Mafic volcanic rocks in the contact aureoles are fine-grained dense epidote amphibolites composed primarily of fibrous mats of darkgreen pleochroic hornblende and plagioclase, plus lesser amounts of biotite, epidote, quartz, and magnetite. In one locality, about 1 mile south of Arnold Pond, the amphibolite contains hornblende that has exsolved lamellae of cummingtonite.

\section{STRUCTURE}

The pre-Silurian rocks in the Cupsuptic and Arnold Pond quadrangles lie in the core of the Boundary Mountain anticlinorium (Albee, 1961), the dominant structural feature of northern New Hampshire and west-central Maine. Silurian and Devonian rocks in the northwest and southeast part of the map area occupy subsidiary synclines on and near the flanks of the anticlinorium and are believed to be separated from the pre-Silurian rocks by the Taconic unconformity.

A marked difference in the style of folding and the intensity of deformation occurs in the rocks above and below the Taconic unconformity. The unconformity and overlying rocks are warped into rather open northeast-trending folds that have gently dipping limbs, steeply dipping axial surfaces, and gently plunging axes. In contrast to this style of deformation, the pre-Silurian rocks contain northeast- and northwest-trending isoclinal folds that have essentially vertical axial 
surfaces and variable but steeply plunging axes. Near the quartz monzonite plutons in the Cupsuptic quadrangle and along the southern border of the map area the major folds and related minor structural features are deformed by north-trending, essentially vertical, slip cleavage that apparently formed during the intrusion of the major igneous bodies.

The contrasting style and degree of deformation above and below the Taconic unconformity, coupled with the fact that coarse-grained polymict metaconglomerate of Silurian age truncates both the Dixville and Albee Formations in the southeastern part of the Cupsuptic quadrangle, indicates that the pre-Silurian rocks in this area were folded, uplifted, and eroded during the Taconic orogeny in Late Ordovician to earliest Silurian time. However, the major period of folding that warped the Taconic unconformity and the overlying rocks into the northeast-trending Boundary Mountain anticlinorium was post-Early Devonian and was related to the Acadian orogeny. Intrusion of the nonfoliated quartz monzonite plutons followed the main stage of Acadian folding. Major high-angle reverse faults accompanied the Acadian folding in the northwest part of the area, and thrust faulting and normal faulting accompanied or postdated the Acadian folding in the southeastern part.

\section{ACADIAN FOLDS IN THE SILURIAN AND DEVONIAN ROCKS}

Although the Acadian folds in the Silurian and Devonian rocks have a consistent northeast trend, major differences in the style of deformation occur in the three areas where these folds are found. In the northwestern part of the map area, the Devonian Seboomook Formation occupies the troughs of the Deer Brook syncline (pl. 1) (Harwood, 1969a) and a major drag fold, cut off by a thrust fault, on its southeast limb. The vertical axial surface of the drag fold trends about N. $20^{\circ} \mathrm{E}$. and converges on the trace of the Deer Brook syncline which trends about N. $35^{\circ} \mathrm{E}$. The green slate and metasiltstone unit and red slate unit on the northwest limb of the Deer Brook syncline have been warped into several small folds that expose rocks of the Dixville Formation in the cores of anticlines near Upper Black Pond and Abbie Pond (pl. 1). All these subsidiary folds are overturned or asymmetric to the east with the axial surfaces dipping $60^{\circ}$ to $80^{\circ} \mathrm{NW}$. and the axes plunging $10^{\circ}$ to $30^{\circ} \mathrm{NE}$. The short limb of the asymmetric minor folds and the inverted limb of the overturned minor folds related to the Deer Brook syncline commonly contain boudinaged beds. The southeast limb of the doubly plunging anticline at Abbie Pond and part of the southeast limb of the Deer Brook syncline are truncated by high-angle reverse faults. The west-over-east movement sense on these faults, 
inferred from the absence of stratigraphic units, is compatible with the direction of overturning of the folds and suggests that the faulting and folding were contemporaneous.

The greenstone, graywacke, and slate northwest of the Deer Brook syncline, previously thought to be Devonian by Marleau $(1957,1959)$, Hatch (1963), Green (1968), and Green and Guidotti (1968), have recently been correlated with the Middle Ordovician Dixville Formation by Harwood (1969a). This narrow, northeast-trending belt of rocks is inferred to form a subsidiary anticline, named the "Second Lake anticline" by Harwood (1969a), on the northwest limb of the Boundary Mountain anticlinorium because (1) the rocks underlie red and green slate units of probable Late Silurian age on the northwest limb of the Deer Brook syncline, (2) they are continuous with the Dixville Formation to the southwest, and (3) they are intruded by serpentinite, which is known to intrude only Middle Ordovician or older rocks elsewhere in the northern Appalachians.

In the outlier of Silurian rocks east of Parmachenee Lake (pl. 1, inset map A) parts of two small doubly plunging synclines of metalimestone are preserved in a down-dropped fault block. The axial surface of the eastern syncline and the axial surfaces of folds in the basal metaconglomerate and quartzite member trend about N. $40^{\circ}$ E. and are essentially vertical. The axes of the symmetric minor folds plunge northeast and southwest at shallow angles. Transposition of bedding and boudinage structures were found in these rocks only adjacent to the northern fault, which parallels the axial surfaces of the minor folds.

Near Johns Pond (pl. 1) in the southeastern port of the Cupsuptic quadrangle the metaconglomerate members of the Rangeley formation outline a broad syncline whose axis trends N. $20^{\circ}$ E. and plunges about $20^{\circ} \mathrm{NE}$. Although exposures are scarce in the central part of this area, the limbs of the syncline appear to dip $40^{\circ}$ or less, and minor folds are symmetrical about vertical axial surfaces. E. L. Boudette (written commun, 1969) reported that rocks on strike northeast of those near Johns Pond have been folded into several northeast-plunging folds which, in turn, have been repeated and offset by several northeast-trending faults. A similar pattern of complex folds and faults may exist in the lowland near Johns Pond, but not enough exposures are available to unequivocally establish these possible structures. Instead, one major southeast-dipping thrust fault is inferred to offset the quartz-pebble metaconglomerate member of the Rangeley at Johns Pond and to isolate a sliver of quartz-pebble metaconglomerate beneath the fault on the west bank of the Kennebago River about 3 miles to the southwest. 


\section{ACADIAN FOLDS IN THE PRE-SILURIAN ROGKS}

Throughout the belt of pre-Silurian rocks in the central part of the map area are several major folds, which have axial surfaces that trend about N. $40^{\circ}$ E. and, thus, closely parallel the trend of the folds in the overlying Silurian and Devonian rocks. The plunge of these major folds and their related minor structural features, however, is generally steep and extremely variable, ranging from $0^{\circ}$ to $90^{\circ}$ NE. or SW.

In the northwestern part of the Cupsuptic quadrangle, graded beds in the Magalloway Member of the Dixville Formation and pillow structures in greenstone at the contact with the black slate member indicate that the Magalloway Member orerlies the black slate member. The Magalloway Member in the valley of the First East Branch of the Magalloway River, therefore, is interpreted to be in a northeast-trending syncline, the First East Branch syncline (pl. 1), whose axial trace is approximately parallel to the trace of the Deer Brook syncline. The Magalloway Member in the First East Branch syncline is separated from the Magalloway Member to the east by an overturned anticline that contains greenstone and black slate of the black slate member of the Dixville. Both these folds plunge northeast, and the orerturned anticline containing the black slate member plunges beneath the Magalloway Member just north of marker post 455 on the international boundary.

In the west-central part of the Cupsuptic quadrangle, the black slate member of the Dixville Formation outlines the nose of the Black Cat anticline (pl. 1) which exposes the Portage Brook Member and, locally, the Kennebago Member of the Albee Formation in its core. There are two axial culminations in this major anticline, generally located in the outcrop areas of the Kennebago Member and separated by an axial depression near the South Branch of Black Cat Brook (pl. 1). The attitude of bedding and the plunge of linear features in these areas indicate that the major fold plunges $70^{\circ}$ to $80^{\circ}$ away from the axial culminations.

The black slate member of the Dixville Formation appears on the southeast limb of the Black Cat anticline west of No. 2 Camp on the Cupsuptic River and in the Green Top syncline north of Lincoln Pond (pl. 1). In the Green Top syncline, the black slate member of the Dixville is preserved in an axial depression made by the intersection of the Green Top syncline and a syncline that was formed earlier and trends west-northwest. The plunge of the Green Top syncline ranges from $30^{\circ}$ to $70^{\circ} \mathrm{NE}$. and SW., and the lower plunges are near the inferred trace of the early syncline; this indicates that the 
plunge of the Green Top syncline passes through the horizontal at the trace of the early syncline.

In the southern and southeastern parts of the Cupsuptic quadrangle, a series of northeast-trending folds is outlined by lithologic units in the Deer Mountain Member of the Albee Formation. The doubly plunging Deer Mountain syncline (pl. 1) is separated from tight isoclinal folds in the Deer Mountain Member to the east by an anticline that exposes the Portage Brook Member of the Albee in its core. Although northeast trends predominate in these folds, the pattern of lithologic units indicates that there are several abrupt deflections in a northwest direction; the most pronounced deflection is about 0.6 mile southwest of Moochers Home (pl. 1). On the 1,740-foot hill southwest of Moochers Home there are magnificent exposures of northeast-trending minor folds superimposed on west-trending minor folds, producing a complex interference pattern of domes and basins. 'The intersection of the major folds that trend northeast and westnorthwest in this area produces the broad doubly plunging pattern of the Deer Mountain syncline and the deviations of unit contacts from the general northeast trend.

At Cloutman Ridge (pl. 1) in the southwestern part of the Cupsuptic quadrangle, the Deer Mountain Member of the Albee Formation is succeeded to the east by a thick lens of greenstone assigned to the Dixville Formation. The greenstone interfingers with and is overlain by the black slate member of the Dixville. Poorly preserved pillow structures at two localities in the greenstone and graded beds in the black slate member on Ephraim Ridge (pl. 1) indicate that this sequence faces east and southeast and is on the west limb of a major syncline.

The Dixville Formation, therefore, appears to be symmetrically arranged on the northwest and southeast limbs of a major anticlinorium in the pre-Silurian rocks which contains the Albee Formation in its core. In detail, however, there are several inconsistencies in the symmetrical arrangement of specific rock units. First, the thick lens of greenstone at the base of the Dixville on the southeast limb of the inferred anticlinorium is missing to the north and west where lenses of greenstone are found only scattered within and at the top of the black slate member. This rapid thinning of the greenstone to the northwest probably reflects the limits of the original volcanic flows that appear to have originated in or near the southeast part of the Cupsuptic quadrangle and extended northward into a basin collecting euxinic sediments.

A similar but somewhat more difficult problem is presented by the absence of the Deer Mountain Member of the Albee below the Dixville on the northwest limb of the inferred anticlinorium. (See pl. 1, 
section $\mathrm{E}-\mathrm{E}^{\prime}$.) At this time the most reasonable solution to this problem is a facies change between the Portage Brook Member and the Deer Mountain Member of the Albee. The bulk of the Deer Mountain Member differs from the Portage Brook Member only in its lower content of arenaceous rocks; the contact between these members is arbitrarily drawn in those areas where the basal black phyllite of the Deer Mountain Member is missing. Thus, the Deer Mountain Member could well be a less arenaceous facies of the Portage Brook Member.

Alternatively, the Dixville Formation could be unconformably above the Albee Formation, in which case the absence of the Deer Mountain Member to the north and west would be due to nondeposition or erosion, or both. This alternative is not favored because of the gradational contacts between the Dixville and the Albee Formations and because of the apparent conformity of the bedding in both formations. Another alternative interpretation, favored by E. L. Boudette (written commun., 1968) from his work to the east, places the northern belt of black slate, greenstone, and graywacke of the Dixville Formation stratigraphically below the Albee and thereby eliminates the need for symmetry of units because all the pre-Silurian rocks would essentially face southeast. This interpretation is not favored here because of the northwest-facing top-sense determinations near the Dixville-Albee contact east of Parmachenee Lake and similar determinations along the Dixville black slate member-Magalloway Member contact about 2 miles west of Cupsuptic Pond (pl.1).

\section{TACONIC UNCONFORMITY}

Many investigators in the northern Appalachians, apparently beginning with Rogers (1838), have noted a break, either an angular unconformity or a disconformity, between the Ordovician and Silurian rocks. Stratigraphic evidence for this break has been discussed most recently by Pavlides, Boucot, and Skidmore (1968).

Although the actual contact between the pre-Silurian and Silurian rocks was not observed in the mapped area because of glacial cover, the divergent attitudes of the beds in the two sequences indicate a major structural break, either an unconformity or a folded thrust fault. In the southeastern part of the Cupsuptic quadrangle, for example, gently dipping beds of the Rangeley Formation rest on steeply dipping beds in the Dixville and Albee Formations, and the Rangeley truncates the Dixville-Albee contact almost at right angles. The lower contact of the Rangeley Formation is interpreted to be an unconformity rather than a thrust fault because the polymict metaconglomerate member of the Rangeley contains abundant clasts of black slate, quartzite, vein quartz, 
and chert and minor amounts of greenstone and green slate apparently derived from the subjacent formations.

Granitic pebbles in the polymict metaconglomerate could have been derived from the granodiorite west of Parmachenee Lake (pl. 1), from the large quartz monzonite body near Jackman, Me. (Boucot and others, 1964), or from the Adamstown Granite of Green and Guidotti (1968) in the northern part of the Oquossoc quadrangle (fig. 1). The absence of clasts of schist and gneiss in the polymict metaconglomerate implies that the pre-Silurian rocks of the source area or areas, were not metamorphosed to a higher grade than chlorite, if at all, prior to the time of erosion. The black and green slate fragments, which are platy but undeformed by adjacent pebbles, have a pronounced cleavage parallel to that in the Silurian rocks. Thus, these fragments probably came from indurated but nonfoliated rocks, probably mudstone or argillite, rather than from unconsolidated mud.

The small patch of polymict metaconglomerate east of Parmachenee Lake (pl. 1) contains clasts of granodiorite that were apparently derived from the intrustive body west of the lake. The abundance of graywacke and greenstone clasts in the conglomerate at Thrasher Peaks (pl. 1) in the northwest part of the Cupsuptic quadrangle also suggests a local origin.

The age limits of the Taconic orogeny in this area can be most closely defined by the late Middle Ordovician graptolites in the Dixville (pl. 1, loc. $\mathrm{O}-1$ ) below the unconformity and by the late Llandovery age for the metaconglomerate above the unconformity. This age span, approximately upper Trenton to lower Clinton, is equal to that given by Pavlides, Boucot, and Skidmore (1969). If the limestone and calcareous slate northeast of Thrasher Peaks (pl. 1) is Ludlow, as tentatively established by Naylor and Boucot (1965) and Green (1968), then the unconformity may represent a greater time span in the northwestern part of the map area.

\section{MAJOR TACONIC FOLDS}

The attitude of the pre-Silurian rocks prior to the major Acadian folding can only be inferred from the map pattern in most of the area. South of Johns Pond (pl. 1), however, the attitude of the Dixville Formation before Acadian folding can be determined by rotating the overlying Silurian rocks to the horizontal and rotating the subjacent pre-Silurian beds a corresponding amount about the same axis. Assuming that the Silurian rocks were deposited on a horizontal surface and were folded along with the pre-Silurian rocks about an axis of $\mathrm{N}$. $58^{\circ} \mathrm{E}$., plunging $18^{\circ} \mathrm{NE}$., the pre-Acadian attitude of the calcareous graywacke near fossil locality $\mathrm{O}-1$ (pl. 1) was N. $62^{\circ}$ E., dipping $62^{\circ}$ 
SE., and was $22^{\circ}$ steeper than at present (Harwood, 1970). It is concluded, furthermore, that the pre-Silurian rocks were warped into major folds, uplifted, and eroded during the Taconic orogeny in this area because the Silurian rocks rest on both the Dixville and the Albee Formations in the southeast and on the Dixville Formation near Parmachenee Lake (pl. 1).

The shape of the Dixville-Albee contact and the distribution of map units about the Kennebago Member of the Albee in the west-central part of the Cupsuptic quadrangle strongly suggest that the preSilurian folds had essentially vertical, west- or northwest-trending axial surfaces. Graded beds near the contacts of map units in this area, indicate that the rocks face outward from the Kennebago Member. Thus, the Dixville Formation in the Green Top syncline is separated from the main body of Dixville to the northeast by an early northwest-trending inferred Taconic anticline cored by the Kennebago Member and from the Dixville to the northwest by a late northeasttrending Acadian anticline (Black Cat anticline) (pl. 1). The Dixville Formation in the Green Top syncline is preserved in a basin-shaped fold formed by the superposition of the late Green Top syncline on an early northwest-trending inferred Taconic syncline. South and east of the Cupsuptic pluton, the Kennebago Member is believed to outline the core of a central anticline that separates the Dixville to the north from the Dixville to the southeast.

Thus, the Dixville and the Albee Formations were apparently folded into a series of major west- or northwest-trending isoclinal anticlines and synclines during the Taconic orogeny. These major folds, cored by the Albee Formation and flanked by the Dixville Formation, constitute a northwest-trending anticlinorium of Taconic age, not to be confused with the northeast-trending Boundary Mountain anticlinorium, cored by pre-Silurian and overlain by Silurian and Devonian rocks that formed during the Devonian Acadian orogeny.

The age of the west- and northwest-trending folds in the Magalloway Member of the Dixville Formation in the northeast part of the Cupsuptic quadrangle is uncertain. Their attitude is similar to that of the Taconic folds outlined by the Dixville-Albee contact, and they appear to be warped by the extension of the northeast-trending Black Cat anticline near Kennebago Divide (pl. 1), but there are no Silurian rocks near them to establish the trend of the Acadian folds. These folds in the Magalloway Member are inferred to be Taconic. Possibly, however, both the pre-Silurian and Silurian rocks (now eroded) were compressed into east-trending folds between the Cupsuptic and Seven Ponds plutons at the time of their intrusion. 


\section{MAJOR FAULTS}

\section{FAULTS ASSOCIATED WITH THE DEER BROOK SYNGLINE}

'Two high-angle reverse faults are indicated by the omission of rock units in the Deer Brook syncline. Northwest of the trace of the syncline, the unnamed red slate unit is abruptly cut out on the southeast limb of the doubly plunging anticline at Abbie Pond (pl. 1). To the southwest, the fault is marked by a thin lens of brecciated and silicified intrusive felsite and apparently isolates a thin sliver of greenstone in the footwall northwest of Upper Black Pond (pl.1).

Southeast of the trace of the Deer Brook syncline, a second northeast-trending high-angle reverse fault isolates a sliver of the Silurian and Devonian green slate and metasiltstone unit in the hanging wall and cuts out the calcareous slate and metalimestone unit on the nose and northwest limb of a small anticline cored by greenstone and graywacke of the Magalloway Member. Southwestward along the inferred trace of the fault there is little stratigraphic control of its position. There are, however, notable areas of brecciated and silicified rock such as at the intersection of the Parmachenee town line and lat. $45^{\circ} 15^{\prime} \mathrm{N}$. and along the southeast contact of the Devonian intrusive felsite on the northeast end of Thrasher Peaks (pl. 1).

These faults parallel the dominant northeast-trending cleavage and have a west-over-east movement sense similar to the asymmetric folds in the Silurian and Devonian rocks. The faults clearly postdate the Seboomook Formation and the Devonian intrusive felsite, which may be a syntectonic intrusive rock. It is concluded, therefore, that the faults probably formed during the late stages of the Acadian deformation.

\section{FAULTS IN THE SILURIAN ROGKS EAST OF PARMACHENEE LAKE}

Two essentially vertical normal faults cut the Silurian rocks east of Parmachenee Lake (pl. 1) and form a central graben in which the youngest metalimestone unit is exposed. The northern fault is not conspicuously marked by silicification or gouge, but closely spaced shear fractures obliterate the bedding in the argillaceous metalimestone unit within 50 feet of the fault. The southern fault, which is locally marked by pods of quartz and calcite as much as 2 feet thick, brings successively younger rocks in the graben into contact with the basal rocks on the south side of the Silurian outlier. These relationships are clearly visible at 1,680 feet altitude in and adjacent to the small unnamed brook that flows along the trace of the fault.

The faults in the Silurian rocks east of Parmachenee Lake must be post-Late Silurian and are probably related to the Acadian orogeny. 


\section{FAULT AT LITTLE KENNEBAGO LAKE}

Granodiorite of inferred Ordovician age is intensely fractured, sericitized, and silicified along a northeast-trending fault zone as much as 200 feet wide east of Little Kennebago Lake (pl. 1). The granodiorite in this zone contains massive quartz veins and abundant small solution channels and vugs lined with euhedral quartz crystals. No sulfide mineralization was seen.

Because of the lack of stratigraphic units along the fault, the dip and direction of movement on the fault are not precisely known. Fractures in the granodiorite suggest a vertical or steeply northwestdipping fault zore in which the northwest block moved up in relation to the southeast block.

\section{FAULT AT DADDYS RIDGE}

South of the 2.385-foor Summit of Daddys Ridge in the southeast part of the Cupsuptic quadrangle, rocks of the Deer Mountain Member of the Albee are offset along a northwest-trending, vertical normal fault. The trace of the fault on Daddys Ridge is locally marked by massive stringers of quartz and calcite and by a dike of sericitized granite. Unaltered quartz monzonite dikes intrude the fault at the southwest corner of the Cupsuptic pluton.

The apparent left-lateral offset of the axis of the anticline in the black phyllite on Daddys Ridge suggests that the northeast block of the fault moved up and to the northwest relative to the southeast block.

\section{FAULT AT JOHNS POND}

A southeast-dipping thrust fault that has a southeast-over-northwest movement sense is inferred to offset the Rangeley Formation in the lowland near Johns Pond and to isolate a thin sliver of the basal quartz-pebble metaconglomerate member in the footwall about 3 miles southwest of Johns Pond. The displacement on the fault, inferred from the apparent separation of the quartz-pebble conglomerate member, is 700 to 900 feet. Quartz pebbles in the slice of conglomerate on the west bank of the Kennebago River are slightly elongated down the southeast dip of the bedding which, in this area, also seems to be the dip of the fault.

The inferred thrust fault is not parallel to the vertical axial surfaces of the folds in the Rangeley Formation, and it seems to postdate the folding but it is probably related to the Acadian deformation. The sliver of conglomerate and the inferred thrust fault are offset by a normal fault that trends east-northeast and is conspicuously marked by gouge and alteration in the underlying Albee Formation on the west bank of the Kennebago River. 


\section{OTHER FAULTS}

Several faults mapped by E. L. Boudette (written commun., 1969) in the Kennebago Lake and Chain Lakes quadrangles (fig. 1) to the east apparently extend into the Cupsuptic quadrange. Because of the lack of exposure where the faults enter the Cupsuptic quadrangle, the faults could not be mapped in the field, and their inferred traces are shown for consistency of mapping and as a guide to future workers in the area.

\section{MINOR STRUCTURAL FEATURES}

\section{FOLIATION}

Foliation is used here in the broad sense defined by Mead (1940) and includes a variety of plannar features such as slaty cleavage, crenulated foliation in phyllite, and schistosity, all of which were apparently formed during the major period of Acadian folding.

Distinct slaty cleavage with dull cleavage surfaces is common in the Silurian and Devonian pelitic rocks and in the pre-Silurian rocks in the eastern part of the Cupsuptic quadrangle. The argillaceous rocks in the central and western part of the Cupsuptic quadrangle are phyllites that have crenulated, shiny foliation surfaces, whereas similar rocks in the southern part of the map area are chlorite-muscovite schists. The change from slaty cleavage to phyllitic cleavage to schistosity southwestward across the Cupsuptic quadrangle reflects a progressive recrystallization of the micaceous minerals during regional metamorphism and is compatible with the general southerly increase in metamorphic grade in this part of the northern Appalachians shown bs Green and Guidotti (1968) and Thompson and Norton (1968).

In much of the Albee Formation the foliation is parallel, or nearly parallel, to the bedding; both dip at steep angles. The foliation crosscuts the bedding at the noses of minor folds and is parallel to the axial surface of the minor folds. The most common trend of the foliation is about $\mathrm{N} .45^{\circ} \mathrm{E}$., but major deviations are found near intrusive bodies. In contrast to the parallel bedding and foliation in the Albee, the foliation in the Silurian and Devonian rocks dips steeply and intersects the gently dipping bedding at a large angle.

There seems to be no pervasive foliation whose attitude can be unequivocally related to the major west- or northwest-trending Taconic folds. Locally in the Green Top syncline, however, west-trending, essentially vertical slaty cleavage makes a slight angle with the bedding; both this cleavage and bedding are deformed by a prominent northeast-trending cleavage. The west-trending slaty cleavage may have formed during the Taconic folding. 


\section{FOLIATION IN THE IGNEOUS ROCKS}

Primary foliation is not a common feature in the plutonic igneous rocks except in the granodiorite in the northeast part of the Arnold Pond quadrangle where oriented flakes of biotite and, to a lesser extent, plates of hornblende and plagioclase define steeply dipping to vertical foliation planes. The trend of the foliation changes from northwest in the southern part of the body to north in the western part. These trends conform to the contact with the surrounding quartz monzonite and to the trend of the narrow roof pendants of metamorphic rocks in the quartz monzonite. Where the granodiorite is exposed in a vertical face, such as at the south end of Crosby Pond (pl. 1), hornblende crystals can be seen to plunge $30^{\circ}$ to $40^{\circ} \mathrm{N}$. within the plane of foliation. The foliation is interpreted to be a primary igneous foliation because it is generally restricted to the granodiorite and does not conform to the general northeast-trending cleavage in the Devonian metasedimentary rocks.

The large quartz monzonite bodies lack foliation except adjacent to the narrow roof pendants in the Seven Ponds pluton and in the chilled contact facies of the Cupsuptic and Lincoln Pond plutons. In these areas biotite flakes are oriented approximately parallel to the contact with the country rock.

\section{SLIP GLEAVAGE}

Slip cleavage is used here in the sense of White (1949) for closely spaced, parallel zones or planes along which transposition of a preexisting planar feature such as bedding or foliation has occurred. As such, it is analogous to strain-slip cleavage of Turner and Weiss (1963, p. 98) and fracture cleavage of Leith (1905, p. 120). Slip cleavage is strongly developed in rocks south and west of the Cupsuptic pluton and in a separate zone along the southern boundary of the Cupsuptic quadrangle.

Vertical slip cleavage in the southern part of the mapped area commonly strikes within $10^{\circ}$ of north, but the strike changes to about N. $40^{\circ}$ E. in the area immediately west of the Cupsuptic pluton. The width of the shear planes and the spacing between them ranges from less than a millimeter to a few centimeters (Fig. 8). The most closely spaced and pervasive slip cleavage was found on and east of Deer Mountain (pl.1) on the southern border of the Cupsuptic quadrangle. Areas of intensely developed slip cleavage extend into areas crossed by widely spaced kink bands that have the same orientation and shear sense as the slip cleavage. 


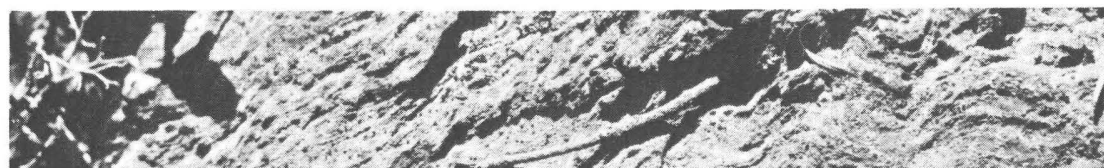

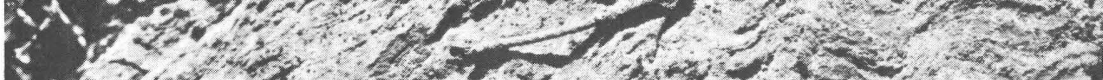

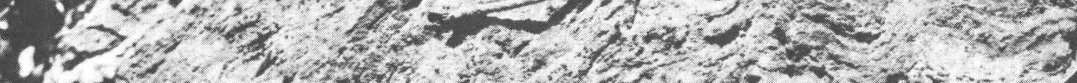

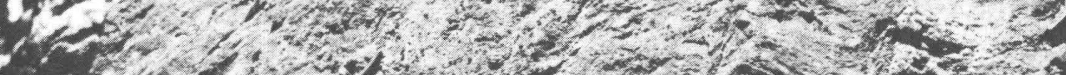

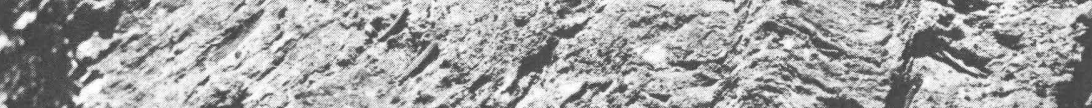

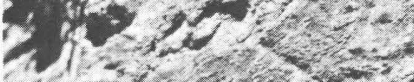

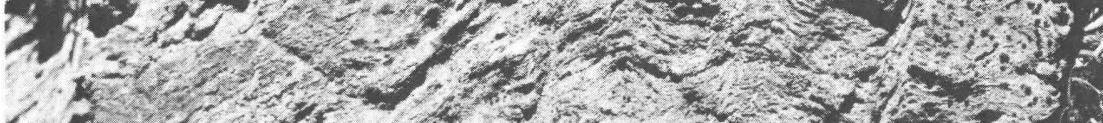

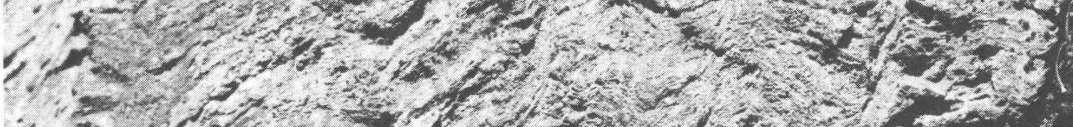

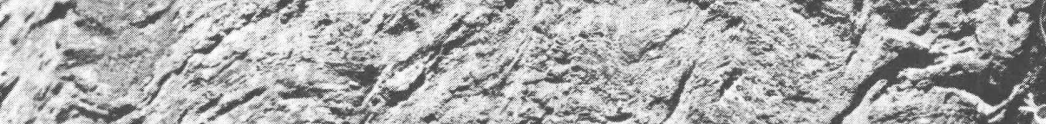

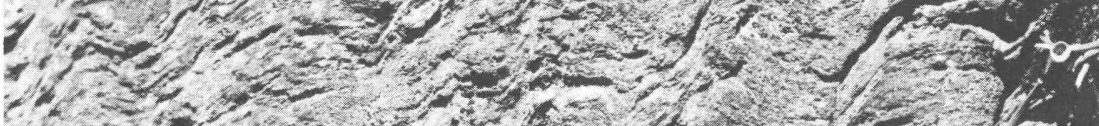

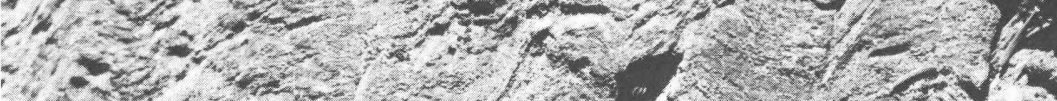

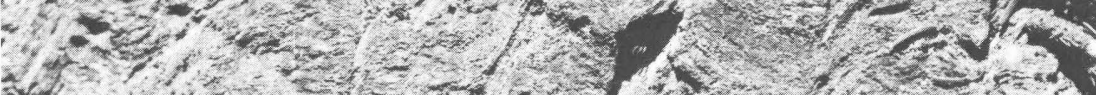

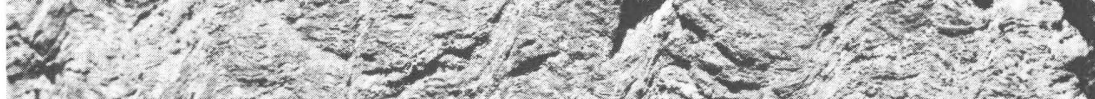

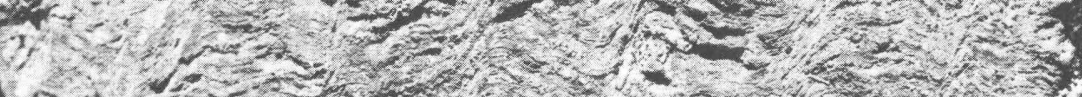

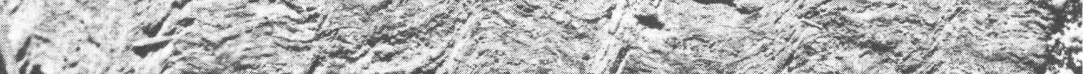

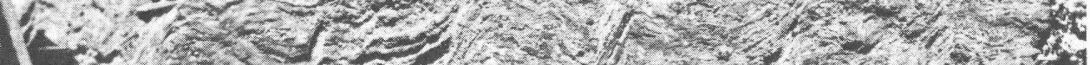

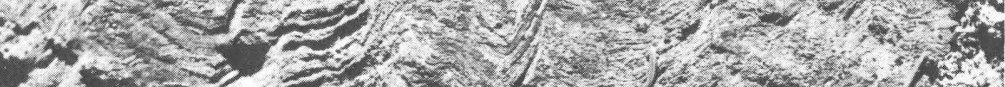

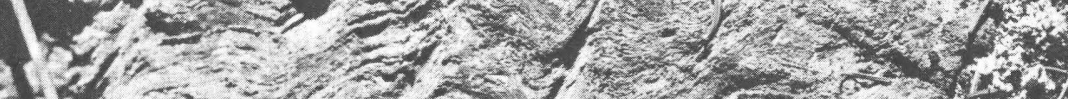

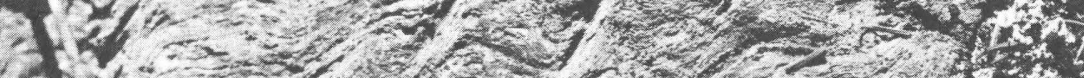

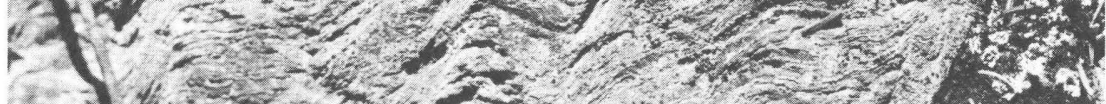

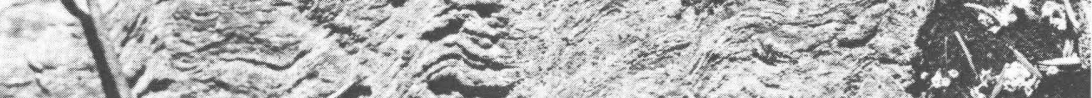

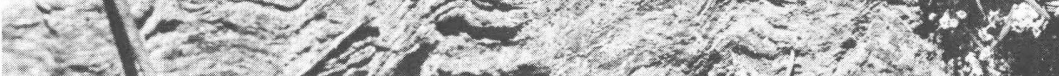

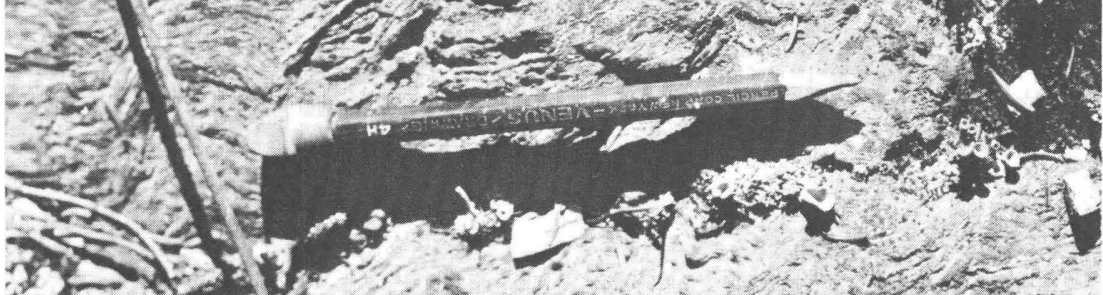

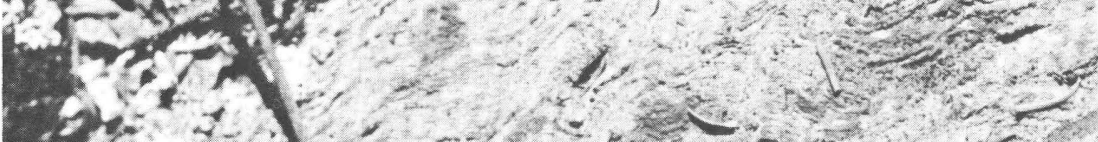

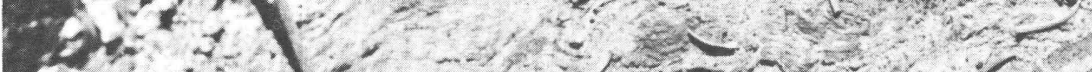
$\int_{1}-x^{2} y$ 


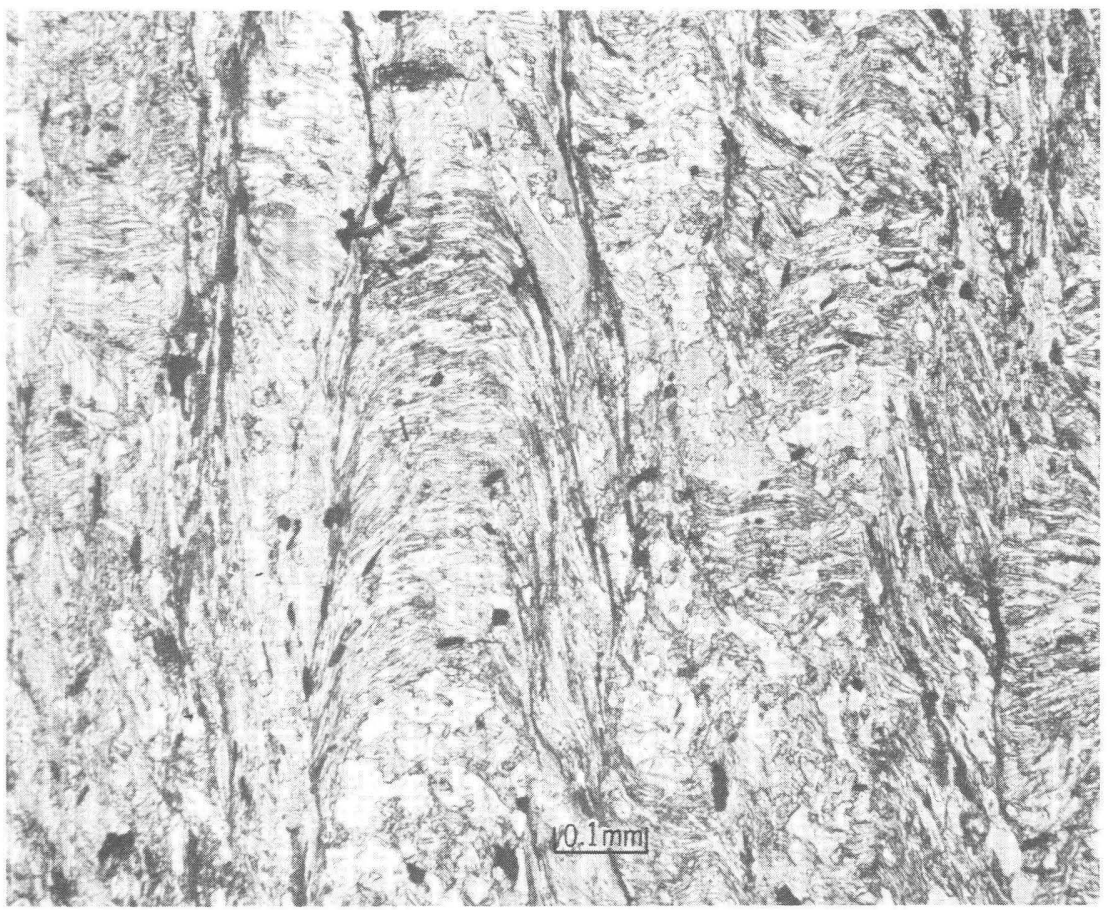

Figure 8.-Slip cleavage crossing foliation in the Portage Brook Member of the Albee Formation on the summit of Deer Mountain. Left: Widely spaced, near-vertical, north-trending slip cleavage crossing northeasttrending foliation in outcrop (plan view). Southeast-trending glacial striations cross the outcrop from upper left to lower right. Above: Photomicrograph of closely spaced slip cleavage (vertical) crossing foliation at right angles. Plane-polarized light.

As shown in figure 8, the slip cleavage clearly postdates and deforms the prominent northeast-trending foliation and invariably produces a steeply plunging lineation, either a minor fold or crenulation, on the early foliation.

\section{MINOR FOLDS}

Minor folds are common and represent a wide variety of forms depending on the development and orientation of the foliation and slip cleavage. In the Silurian and Devonian rocks the minor folds are generally open flexures that have vertical axial surfaces and gently plunging axes, except in the Deer Brook syncline where they are asymmetric or overturned and commonly contain boudinaged beds in the short or overturned limbs. The direction and amount of plunge of the minor fold axes in the Silurian and Devonian rocks are constant within an 
outcrop and generally are constant within a given part of the map area.

The minor folds in the pre-Silurian rocks, on the other hand, vary in wavelength and amplitude (fig. 9) and vary rapidly in direction and amount of plunge of the axes. For example, the axis of the fold in figure 10 plunges about $5^{\circ} \mathrm{NE}$., passes through the horizontal, and plunges about $31^{\circ} \mathrm{SW}$. within a distance of 2 feet. Larger folds in the same area have similar variations over a distance of 13 feet. The axial surfaces of the folds have a constant northeast trend. These hogback folds may have formed by differential movement in the $a$ direction of the fold or by the superposition of northeast-trending Acadian folds on northwest-trending, gently plunging Taconic folds. No northwesttrending Taconic foliation or lineation is preserved in the outcrop, so the origin of these folds cannot be unequivocally established.

In areas where the slip cleavage is strongly developed, such as on the southeast slope of Deer Mountain, the minor folds are the most complex of any in the map area. Typical examples are sketched in figure 11. Two generations of minor folds are easily recognized-one set has the early northeast-trending foliation parallel to its axial

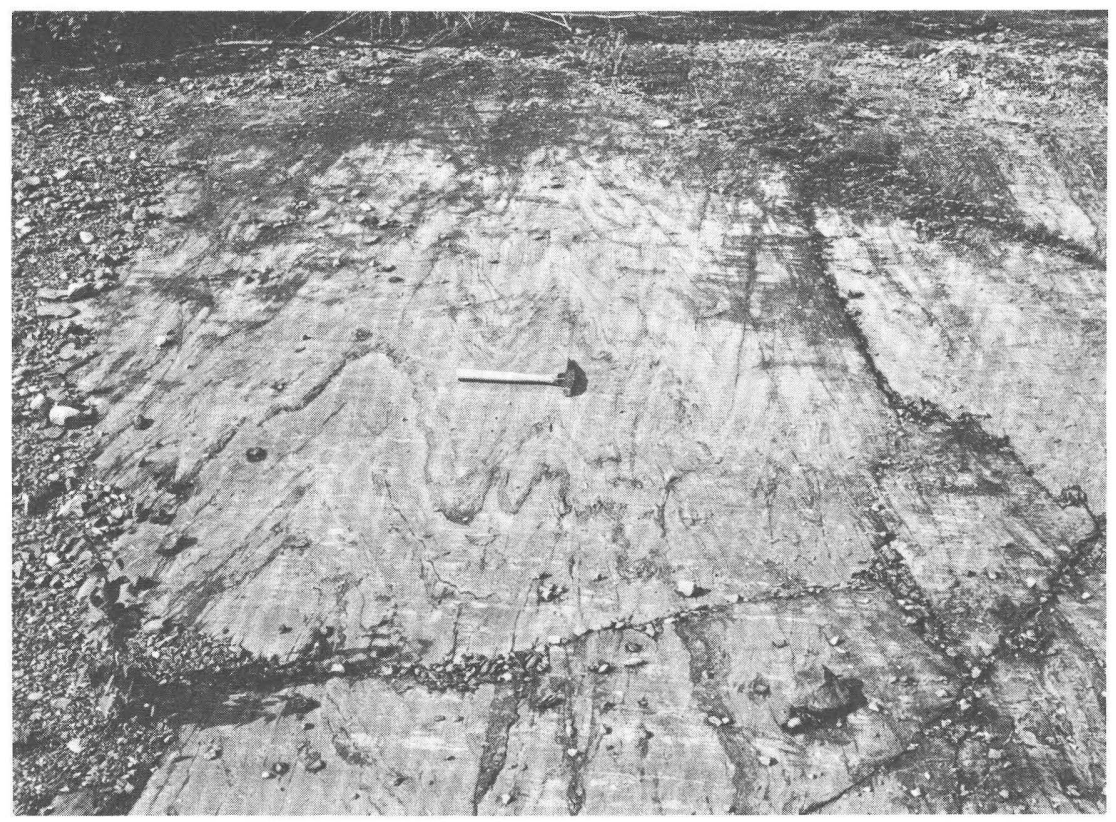

Figure. 9.-Minor folds of variable wavelength and amplitude in the Albee Formation near the west bank of the Cupsuptic River, 0.25 mile west of Camp Dorothy. View looking southwest. 
surface and the second set has the slip cleavage parallel to its axial surface. The early northeast-trending minor folds have steeply plunging axes and essentially vertical limbs. The late folds invariably have steep-plunging to vertical axes parallel to the intersection of the vertical slip cleavage and the near vertical bedding and (or) early foliation.

\section{LINEAR FEATURES}

The linear features measured in the area include axes of minor folds, minor crenulations in the bedding or foliation, quartz rods, bedding-cleavage intersections, and a few bedding-boudinage lines. Over much of the area the combination of steeply plunging folds and flat, pavementlike outcrops restrict the observable linear features to hinge lines of minor folds.

Minor fold axes.-Axes of minor folds are abundant in the Albee Formation and constitute the bulk of the linear features measured in the southern half of the quadrangle. In the Aziscohos Formation, the hinge lines of folded quartz stringers are virtually parallel to either the early or late fold axes in the bedding.

Crenulations.-Minor crenulations are common in the foliation. The crenulations are minor folds, but their amplitude and wave length are

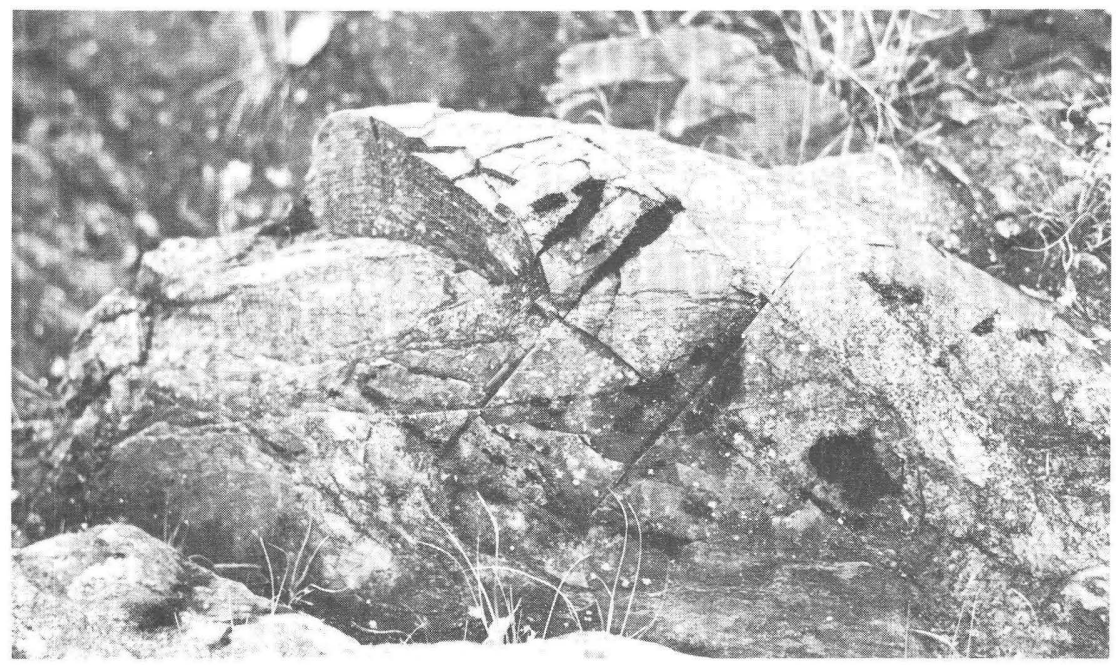

Figure 10.-Hogback fold in feldspathic quartzite of the Kennebago Member of the Albee Formation. Axial surface of the fold trends northeast and is vertical; fold axis plunges $31^{\circ} \mathrm{SW}$, at right of photograph, passes through the horizontal in the center, and plunges $5^{\circ} \mathrm{NE}$. near left part of photograph. Fold is about 2 feet long. In gorge of Kennebago River 100 feet south of dam at outlet to Kennebago Lake. 
on the order of a few millimeters or tenths of millimeters. The crenulations commonly have axes parallel to the hinge lines of minor folds in bedding and are formed about the slip cleavage.

Quartz rods.-Quartz rods are abundant in parts of the Albee and Aziscohos Formations. They represent sheared and transposed fold hinges and planar segments of quartz stringers that lie in zones of pronounced shearing parallel to the slip cleavage direction. The plunge of the quartz rods is parallel to the intersection of the slip cleavage and the foliation.

\section{ECONOMIC GEOLOGY}

No mines or quarries are in the map area, but considerable exploration has been done over the past 15 years along a discontinuous belt of sulfide mineralization that extends at least from Rump Pond in the
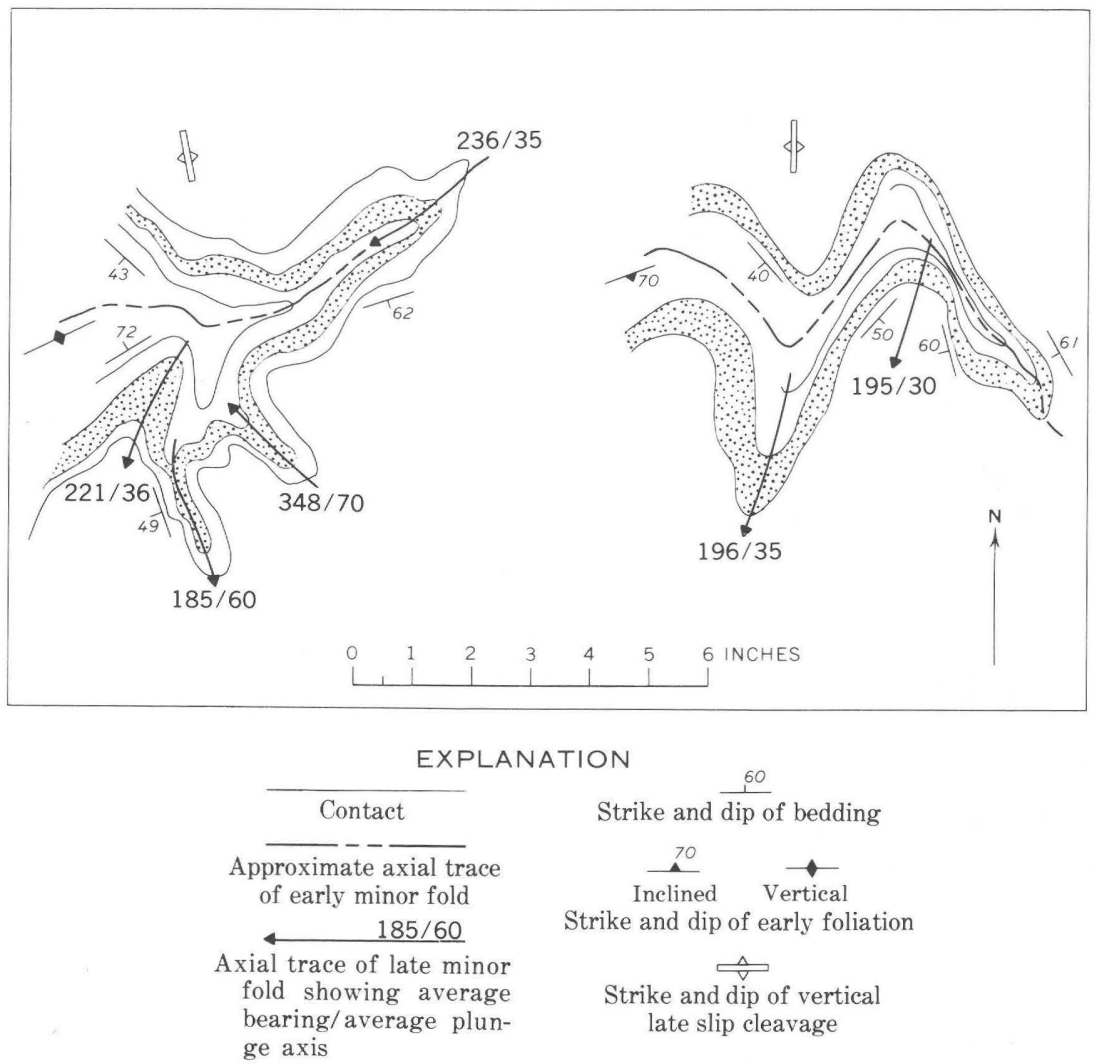

Figure 11.-Sketches of minor folds in feldspathic quartzite beds of the Albee Formation refolded about late slip cleavage. On the east slope of Deer Mountain. Pattern used only to facilitate map interpretation. 
Second Lake quadrangle (fig. 1) northeastward along the southeast slope of Thrasher Peaks (pl. 1) in the northwest part of the Cupsuptic quadrangle. Young (1968, p. 132-133) briefly discussed the pre-1966 exploration and the general geology of the mineralized area.

In this belt, chalcopyrite and sphalerite associated with pyrite occur in stringers and veins less than 1 inch thick to as much as 8 inches thick. Semiquantitative spectrographic analyses of pyritic graywacke adjacent to an 8-inch vein and of the vein material itself are given in table 6 (samples 1,2).

TABLE 6.-Semiquantitative spectrographic analyses of selected sulfide-rich rocks from the Cupsuptic-Arnold Pond area, Maine

[M=major constituent ( $>10$ percent); $0=$ looked for but not detected. The elements $\mathrm{Au}, \mathrm{Bi}, \mathrm{La}, \mathrm{Pd}, \mathrm{Pt}$ $\mathrm{Sb}, \mathrm{Sn}, \mathrm{Ta}, \mathrm{Te}$, and $\mathrm{W}$ were looked for in all samples but were not detected. Analyst: William B. Crandell

\begin{tabular}{|c|c|c|c|c|c|}
\hline & 1 & 2 & 3 & 4 & 5 \\
\hline $\begin{array}{l}\mathrm{Fe} \\
\mathrm{Mg} \\
\mathrm{Ca} \\
\mathrm{Ti}\end{array}$ & $\begin{array}{l}\mathrm{M} \\
5.0 \\
.03 \\
.07 \\
.1\end{array}$ & $\begin{array}{l}\mathrm{M} \\
\quad .2 \\
.03 \\
.015 \\
.01\end{array}$ & $\begin{aligned} & 3 . 0 \\
& 3 . 0 \\
& 10 . 0 \\
& .05 \\
& .1\end{aligned}$ & $\begin{aligned} \text { 10. } 0 \\
10.0 \\
\text { 7. } 0 \\
.03 \\
.15\end{aligned}$ & $\begin{array}{l}2.0 \\
\mathrm{M} \\
\quad .07 \\
.1\end{array}$ \\
\hline 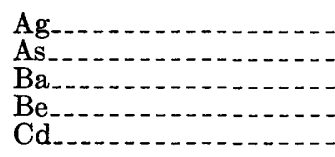 & $\begin{array}{l}0.0003 \\
0.0015 \\
0.02\end{array}$ & $\begin{array}{l}.007 \\
.1 \\
0.001 \\
.1\end{array}$ & $\begin{array}{l}0 \\
.3 \\
.05 \\
.0002 \\
0\end{array}$ & $\begin{array}{l}0 \\
0 \\
0 \\
0 \\
0\end{array}$ & $\begin{array}{l}0 \\
0 \\
.03 \\
.0001 \\
0\end{array}$ \\
\hline $\begin{array}{l}\mathrm{Co} \\
\mathrm{Cr} \\
\mathrm{Cu} \\
\mathrm{Mo} \mathrm{M}_{2} \\
\mathrm{Nb}\end{array}$ & $\begin{array}{l}.03 \\
.0007 \\
2.0 \\
.001 \\
.0003\end{array}$ & $\begin{array}{l}.15 \\
.0003 \\
7.0 \\
.0015 \\
.0003\end{array}$ & $\begin{array}{l}.003 \\
.7 \\
.001 \\
.0005 \\
0\end{array}$ & $\begin{array}{l}.002 \\
3.0 \\
.0015 \\
.0003 \\
0\end{array}$ & $\begin{array}{l}.0005 \\
.0015 \\
.003 \\
.0005 \\
.0005\end{array}$ \\
\hline $\begin{array}{l}\mathrm{Ni} \\
\mathrm{Pb} \\
\mathrm{Sr} \\
\mathrm{V} \\
\mathrm{Y}\end{array}$ & $\begin{array}{l}.0015 \\
.001 \\
.0015 \\
.0015\end{array}$ & $\begin{array}{l}.001 \\
.015 \\
0 \\
.0007\end{array}$ & $\begin{array}{l}.5 \\
.0015 \\
.3 \\
.02 \\
0\end{array}$ & $\begin{array}{l}0^{2} \\
.05 \\
.015 \\
.0007\end{array}$ & $\begin{array}{l}.001 \\
.001 \\
.02 \\
.002 \\
.0015\end{array}$ \\
\hline $\mathbf{Z n}_{\mathbf{Z}_{2}} \ldots$ & $\begin{array}{l}\text { 5. } 0 \\
.003\end{array}$ & ${ }_{.001}$ & $\begin{array}{l}0 \\
0\end{array}$ & $0^{1}$ & ${ }^{0} .002$ \\
\hline
\end{tabular}

1. Pyritic graywacke of Magalloway Member of Dixville Formation adjacent to pyrite-chalcopyrite-sphalerite vein at north side of logging road, 2,900 feet S. $34^{\circ}$ E. from outlet to Caribou Pond, Second Lake quadrangle.

2. Pyrite-chalcopyrite-sphalerite rock from 8 -inch vein; same location as sample 1 .

3. Light-gray feldspathic segregation in dark-green amphibolite associated with serpentinite; 1,700 feet $\mathrm{N}$.

$14^{\circ} \mathrm{W}$. from north inlet to Arnold Pond, Arnold Pond quadrangle.
4. Dark-green amphibolite that contains minor amounts of disseminated chromite; same location as sample 3.

5. Quartz-garnet-calcite skarn about 2 inches thick at contact of quartz monzonite and calcite vein (30 feet wide); 3,600 feet S. $13^{\circ} \mathrm{E}$. from outlet of Arnold Pond, Arnold Pond quadrangle.

The sulfide stringers are generally parallel to the pronounced northeast-trending cleavage in the schistose feldspathic graywacke and interbedded slate and felsic metavolcanic rocks of the Magalloway Member of the Dixville Formation. The sulfide minerals do not seem 
to be consistently confined to any distinct lithologic layer, but the exposed sulfide stringers on Thrasher Peaks are found below the steeply northwest-dipping lens of greenstone in the Magalloway Member. The sulfide minerals lie along the traces of the inferred high-angle reverse fault and are, in part, the justification for extending the fault southwest of the Arnold Pond quadrangle. No sulfide mineralization was found along the trace of the inferred fault or below the lens of greenstone in the Arnold Pond quadrangle, adjacent to Thrasher Peaks. Whether the lens or greenstone or the inferred fault, or both, served to localize the sulfide minerals or whether the mineralization is unrelated to these features is unknown.

Disseminated grains of chromite associated with magnetite were found in the layer of amphibolite adjacent to the serpentinite body 0.25 mile north of Arnold Pond (pl. 1) in the northeastern part of the Arnold Pond quadrangle. The dark-green amphibolite contains lightgray, feldspar-rich stringers and segregations that are separated from the amphibolite by partial rims of fine-grained chromite and magnetite a few tenths of an inch thick. Semiquantitative spectrographic analyses of the amphibolite and the feldspathic segregations in the amphibolite are given in table 6 (samples 3,4 ). The analyzed amphibolite specimen contains 3.0 percent chrome, most of which was probably concentrated in a chromite-magnetite layer adjacent to a feldspathic segregation. The amphibolite specimen also contains 0.2 percent nickel and 0.1 percent zinc. Neither the mineralization nor the feldspathic segregations were found elsewhere in the quadrangle.

Arsenopyrite was found in one rubbly outcrop of quartz-pebble conglomerate of the Rangeley Formation north of Johns Pond (pl. 1) in the southeastern part of the Cupsuptic quadrangle. The arsenopyrite occurs in interstices between quartz pebbles and makes up about 1.5 modal percent of the rock where it is most abundant. A combined fire assay-atomic adsorption analysis for gold was run on the arsenopyritebearing conglomerate and a sample of arsenopyrite-free conglomerate from the same outcrop. These results, as well as analyses for gold in the mineralized samples listed in table 6 , are given in table 7 .

Sporadic exploration for asbestos has been done in the serpentinite body at White Cap Mountain in the northeastern part of the Cupsuptic quadrangle and in the serpentinite in the northwesternmost part of the Arnold Pond quadrangle. The smaller serpentinite bodies in the Seven Ponds pluton were unknown before this report. Although all the serpentinite bodies contain some veinlets of slip-fiber and cross-fiber asbestos, none appear to contain economic quantities of asbestos under the present market conditions. The serpentinite in the northwest corner of the Arnold Pond quadrangle contains an estimated 0.1 percent 
of asbestos veinlets (both cross-fiber and slip-fiber), and the other bodies contain significantly smaller amounts.

The equigranular nonfoliated quartz monzonite in the map area is well suited for building stone, curbing stone, and ornamental stone; but, being far from commercial markets, the rock has not been used. The granitic rocks, greenstone, and possibly the graywacke of the Magalloway Member could be used as crushed stone and fill.

TABLE 7.-Combined fire assay-atomic adsorption determinations for gold in selected sulfide-rich samples from the Cupsuptic-Arnold Pond area, Maine

[Analyst: Carol L. Burton]

\begin{tabular}{|c|c|c|}
\hline Sample & $\begin{array}{r}\text { Gold } \\
(\mathrm{ppm})\end{array}$ & $\begin{array}{r}\text { Sample } \\
\text { size } \\
\text { (grams) }\end{array}$ \\
\hline $1 \ldots$ & 0.08 & 10 \\
\hline $2 \ldots$ & $\{.5$ & 15 \\
\hline $3 \ldots$ & $\begin{array}{l}.0 \\
.05\end{array}$ & 15 \\
\hline $4 \ldots$ & $\left\{\begin{array}{l}.08 \\
.05\end{array}\right.$ & $\begin{array}{l}15 \\
15\end{array}$ \\
\hline & 1.07 & 9 \\
\hline $5 \ldots$ & .1 & $?$ \\
\hline $\begin{array}{l}6 \\
7\end{array}$ & .5 & ? \\
\hline
\end{tabular}

1. Pyrite-chalcopyrite-sphalerite rock from 8-inch vein in exploration trench at north side of logging road, 2,900 feet (bearing S. $34^{\circ}$ E.) from outlet to Caribou Pond, Second Lake quadrangle. Sample 2 in table 6.

2. Light-colored amphibolite from intermixed light and dark volcanic rocks associated with serpentinite; 1,700 feet $N .14^{\circ}$ W. of north inlet to Arnold Pond, Arnold Pond quadrangle. Sample 3 in table 6.

3. Dark amphibolite; same locality as sample 2 . Sample 4 in table 6.

4. Quartz-garnet-calcite skarn about 2 inches thick formed at contact between quartz monzonite and calcite vein (30 feet wide); 3,600 feet S. $13^{\circ}$ E. from outlet of Arnold Pond, Arnold Pond quadrangle. Sample 5 in table 6.

5. Arsenopyrite-bearing, quartz-pebble conglomerate of Rangely Formation; 6,400 feet N. $39^{\circ}$ E. of outlet to Johns Pond, Cupsuptic quadrangle.

6. Quartz-pebble conglomerate of Rangley Formation without $\nabla$ isible arsenopyrite. Same location as sample 7. Same as sample 6 .

Sand and gravel in outwash and esker deposits along the major river valleys is used locally in building and maintaining the extensive network of logging roads. The deposits at the head of Aziscohos Lake, along the Magalloway River north of Parmachenee Lake, and in the lowland south of Little Kennebago Lake are composed dominantly of stratified sand and gravel; coarse to medium gravel is predominant. Assuming an average thickness of 10 feet, the deposits at the head of Aziscohos Lake amount to about 10 million cubic yards, those north of Parmachenee Lake contain about 7 million cubic yards, and those south of Little Kennebago Lake contain about 10 million cubic yards. Significant gravel deposits are also found in the eskers along the Cupsuptic River near Fox Pond (pl. 1, along the Beaver Pond Tote Road north of Little Kennebago Lake, and east of the Kennebago 
River near Realty. Large deposits of sand and pea gravel occur on the east side of the Cupsuptic River near Camp Dorothy, at the Cupsuptic Nursery, and at the outlet to Massachusetts Bog (pl. 1). Each of these deposits contains more than 1 million cubic yards; sand is predominant.

\section{REFERENCES CITED}

Albee, A. L., 1961, Boundary Mountain anticlinorium, west-central Maine and northern New Hampshire: U.S. Geol. Survey Prof. Paper 424-C, C51-C54.

Albee, A. L., and Boudette, E. L., 1972, Geology of the Attean quadrangle, Somerset County, Maine : U.S. Geol. Survey Bull. 1297, 110 p.

Berry, W. B. N., 1959, Graptolite faunas of the northern part of the Taconic area [New York-Vermont], Part 3 of Trip G, in New England Intercollegiate Geological Conference, 51st Annual Meeting, Rutland, Vermont, 1959, Stratigraphy and structure of west-central Vermont and adjacent New York: p. 61-62.

1960, Graptolite faunas of the Marathon region, west Texas: Texas Univ. Pub. 6005, 179 p.

_ 1962, On the Magog, Quebec, graptolites: Am. Jour. Sci., v. 260, p. 142148.

Billings, M. P., 1934, Paleozoic age of the rocks of central New Hampshire: Science, new ser., v. 79 , no. 2038, p. 55-56.

1935, Geology of the Littleton and Moosilauke quadrangles, New Hampshire: Concord, New Hampshire State Plan. and Devel. Comm., 51 p.

1937, Regional metamorphism of the Littleton-Moosilauke area, New Hampshire: Geol. Soc. America Bull., v. 48, no. 4, p. 463-566.

1956, Bedrock geology, Part 2 of The geology of New Hampshire: Concord, New Hampshire State Plan, and Devel. Comm., 203 p.

Boucot, A. J., 1961, Stratigraphy of the Moose River synclinorium, Maine: U.S. Geol. Survey Bull. 1111-E, p. 153-188.

Boucot, A. J., Griscom, Andrew, and Allingham, J. W., 1964, Geologic and aeromagnetic map of northern Maine: U.S. Geol. Survey Geophys. Inv. Map GP-312, scale $1: 250,000,7 \mathrm{p}$.

Boynton, G. R., and Gilbert, F. P., 1964, Aeromagnetic map of the Cupsuptic quadrangle, Oxford and Franklin Counties, Maine: U.S. Geol. Survey Geophys. Inv. Map GP-447, scale 1: 62,500.

Cady, W .M., 1956, Bedrock geology of the Montpelier quadrangle, Vermont: U.S. Geol. Survey Geol. Quad. Map GQ-79.

1960, Stratigraphy and tectonic relationships in northern Vermont and southern Quebec: Geol. Soc. America Bull., v. 71, p. 531-576.

1967, Geosynclinal setting of the Appalachian Mountains in southeastern Quebec and northern New England, in Clark, T. H., ed., Appalachian tectonics : Royal Soc. Canada Spec. Pub. 10., p. 57-68.

1968, The lateral transition from the miogeosynclinal to the eugeosynclinal zone in northwestern New England and adjacent Quebec, in Zen, E-an, White, W. S., Hadley, J. B., and Thompson, J. B., Jr., eds., Studies of Appalachian geology-northern and maritime: New York, Intersci. Publishers, p. 151-161.

Cady, W. M., Albee, A. L., and Chidester, A. H., 1963, Bedrock geology and asbestos deposits of the upper Missisquoi Valley and vicinity, Vermont: U.S. Geol. Survey Bull. 1122-B, 78 p. 
Chidester, A. H., 1962, Petrology and geochemistry of selected talc-bearing ultramafic rocks and adjacent country rocks in north-central Vermont: U.S. Geol. Survey Prof. Paper 345, 207 p.

Clifford, T. N., 1960, Spessartine and magnesium biotite in coticule-bearing rocks from Mill Hollow, Alstead Township, New Hampshire, U.S.A. : Neues Jahrb. Mineralogie Abh., v. 94, p. 1369-1400.

Cooke, H. C., 1937, Thetford, Disraeli, and eastern half of Warwick map areas, Quebec: Canada Geol. Survey Mem. 211, 160 p.

Dale, T. N., 1907, The granites of Maine: U.S. Geol. Survey Bull. 313, 202 p.

Doll, C. G., Cady, W. M., Thompson, J. B., Jr., and Billings, M. P., 1961, Centennial geologic map of Vermont: Montpelier, Vermont Geol. Survey, scale $1: 250,000$.

Emerson, B. K., 1898, Geology of Old Hampshire County, Massachusetts, comprising Franklin, Hampshire, and Hampden Counties : U.S. Geol. Survey Mon. $29,790 \mathrm{p}$.

Faul, Henry, Stern, T. W., Thomas, H. H., and Elmore, P. L. D., 1963, Ages of intrusion and metamorphism in the northern Appalachians: Am. Jour. Sci., v. 261, p. 1-19.

Fenneman, N. M., 1938, Physiography of eastern United States: New York, McGraw-Hill Book Co., 714 p.

Green, J. O., 1964, Stratigraphy and structure of the Boundary Mountains' anticlinorium in the Errol quadrangle, New Hampshire-Maine: Geol. Soc. America Spec. Paper 77, 78 p.

1968, Geology of the Connecticut Lakes-Parmachenee area, New Hampshire-Maine: Geol. Soc. America Bull., v. 79, p. 1601-1638.

Green, J. C., and Guidotti, C. V., 1968, The Boundary Mountains anticlinorium in northern New Hampshire and northwestern Maine, in Zen, E-an, White, W. S., Hadley, J. B., and Thompson, J. B., Jr., eds., Studies of Appalachian geology-northern and maritime : New York, Intersci. Publishers, p. 255-266.

Harwood, D. S., 1969a, The Second Lake anticline, a major structure of the northwest limb of the Boundary Mountain anticlinorium, northern New Hampshire, west-central Maine, and adjacent Quebec: U.S. Geol. Survey Prof. Paper 650-D, p. D106-D115.

1969b, Variations in the delta index of cordierite around the Cupsuptic pluton, west-central Maine: Am. Mineralogist, v. 54, p. 896-908.

-1970, Nature of the Taconic orogeny in the Cupsuptic quadrangle, westcentral Maine, in New England Intercollegiate Geological Conference, 62d Annual Meeting, October 2-4, 1970, Guidebook for field trips in the Rangeley Lakes-Dead River basin region, western Maine: [Syracuse, N.Y., Syracuse Univ. Dept. Geology ] p. H1-H19.

Harwood, D. S., and Berry, W. B. N., 1967, Fossiliferous lower Paleozoic rocks in the Cupsuptic quadrangle, west-central Maine: U.S. Geol. Survey Prof. Paper 575-D, p. D16-D23.

Hatch, N. L., Jr., 1963, The geology of the Dixville quadrangle, New Hampshire: New Hampshire Dept. Resources and Econ. Devel. Bull. 1, 81 p.

Hess, H. H., 1949, Chemical composition and optical properties of common clinopyroxenes: Am. Mineralogist, v. 34, p. 621.

Hitchcock, O. H., 1877, Geology of New Hampshire * * * Part II, Stratigraphical geology : Concord, N.H., 684 p.

1878, Atlas accompanying the report on the geology of New Hampshire: New York. 
Holmes, Ezekiel, and Hitcheock, C. H., 1862, Second annulal report upon the natural history and geology of the State of Maine: Maine Board Agriculture 7th Ann. Rept., p. 217-447.

Hussey, A. M., Chapman, C. A., Doyle, R. G., Osberg, P. H., Pavlides, Louis, and Warner, Jeffrey, compilers, 1967, Preliminary geologic map of Maine: Augusta, Me., Maine Geol. Survey, scale 1: 500,000.

Jackson, C. T., 1839, Third annual report on the geology of the State of Maine: Augusta, $276 \mathrm{p}$.

Kane, M. F., and Bromery, R. W., 1966, Simple Bouguer gravity map of Maine: U.S. Geol. Survey Geophys. Inv. Map GP-580, scale 1: 500,000.

Keith, Arthur, 1933, Preliminary geologic map of Maine: Maine Geol. Survey, scale $1: 1,000,000$. (Issued as a supplement to Maine Tech. Expt. Sta. Bull. 30, v. 2,1935 .)

Leith, C. K., 1905, Rock cleavage: U.S. Geol. Survey Bull. 239, 216 p.

Marleau, R. A., 1957, Preliminary report on East Megantic and Armstrong areas, electoral districts of Frontenac and Beauce, Quebec: Quebec Dept. Mines Prelim. Rept. 362, 7 p.

- 1959, Age relations in the Lake Megantic Range, southern Quebec: Geol. Assoc. Canada Proc., v. 11, p. 129-139.

1968, Woburn-East Megantic-Armstrong area, Frontenac and Beauce Counties: Quebec Dept. Nat. Resources Geol. Rept. 131, 55 p. (also French ed.).

Mead, W. J., 1940, Folding, rock flowage, and foliate structures: Jour. Geology, v. 48 , p. $1007-1021$.

Moench, R. H., 1971, Geologic map of the Rangeley and Phillips quadrangles, Franklin and Oxford Counties, Maine: U.S. Geol. Survey Misc. Geol. Inv. Map I-605, scale $1: 62,500$.

Muir, I. D., 1951, The clinopyroxenes of the Skaergaard intrusion, eastern Greenland: Mineralog. Mag., v. 29, p. 690.

Naylor, R. S., and Boucot, A. J., 1965, Origin and distribution of rocks of Ludlow age (Late Silurian) in the northern Appalachians: Am. Jour. Sci., v. 263 , p. $153-169$.

Neuman, R. B., 1968, Paleogeographic implications of Ordovician shelly fossils in the Magog Belt of the northern Appalachian region, in Zen, E-an, White, W. S., Hadley, J. B., and Thompson, J. B., Jr., eds., Studies of Appalachian geology--northern and maritime: New York, Intersci. Publishers, p. 35-48.

Osberg, P. H., Moench, R. H., and Warner, Jeffrey, 1968, Stratigraphy of the Merrimack synclinorium in west-central Maine, in Zen, E-an, White, W. S., Hadley, J. B., and Thompson, J. B., Jr., eds., Studies of Appalachian geology-northern and maritime: New York, Intersci. Publishers, p. 241-253.

Pavlides, Louis, Boucot, A. J., and Skidmore, W. B., 1968, Stratigraphic evidence for the Taconic orogeny in the northern Appalachians, in Zen, E-an, White, W. S., Hadley, J. B. and Thompson, J. B., Jr., eds., Studies of Appalachian geology-northern and maritime: New York, Intersci. Publishers, p. 61-82.

Post, E. V., and Hite. J. B., 1963, Heavr metals in stream sediment, west-central Maine: U.S. Geol. Survey Mineral Inv. Field Studies Map MF-278, scale $1: 250,000$.

Rogers, H. D., 1838, Second annual report on the geological exploration of the State of Pennsylvania : Harrisburg, Pa., $93 \mathrm{p}$.

Smith, E. S. C., 1923, The Rangeley conglomerate: Am. Jour. Sci., v. 5, p. 147-15t. 
Thayer, T. P., 1963, Flow layering in alpine peridotite-gabbro complexes: Mineralog. Soc. America Spec. Paper 1, p. 55-61.

Theokritoff, G., 1964. Taconic stratigraphy in northern Washington County, New York: Geol. Soc. America Bull., v. 75, p. 171-190.

Thompson, J. B., Jr., and Norton, S. A., 1968, Paleozoic regional metamorphism in New England and adjacent areas, in Zen, E-an, White, W. S., Hadley, J. B., and Thompson, J. B.. Jr., eds., Studies of Appalachian geology-northern and maritime: New York, Intersci. Publishers, p. 319-327.

Turner, F. J., and Verhoogen, John, 1960. Igneous and metamorphic petrology [2d ed.] : New York, McGraw-Hill Book Co., 694 p.

Turner, F. J., and Weiss, L. E., 1963, Structural analysis of metamorphic tectonites: New York, McGraw-Hill Book Co., 545 p.

U.S. Geological Survey, 1965, Geological Survey research 1965: U.S. Geol. Survey Prof. Paper 525-A, 376 p.

White, W. S., 1949, Cleavage in east-central Vermont: Am. Geophys. Union Trans., v. 30, p. 587-594.

Williams, Howel, Turner, F. J., and Gilbert, C. M., 1954, Petrography-an introduction to the study of rocks in thin sections: San Francisco, W. H. Freeman and $\mathrm{Co}, 406 \mathrm{p}$.

Young, R. S., 1968, Mineral exploration and development in Maine, in Ridge, J. D., ed., Ore deposits of the United States, 1933-1967 (Graton-Sales Volume) : New York, Am. Inst. Mining Metall. and Petroleum Engineers, v. 1, p. 125-139.

Zen, E-an, 1967, Time and space relationships of the Taconic allochthon and autochthon: Geol. Soc. America Spec. Paper 97. 107 p. 


\section{INDEX}

[Italic page numbers indicate major references]

\begin{tabular}{|c|c|}
\hline age & Page \\
\hline Acknowledgments_. & Gabbro_. \\
\hline Adamstown Granite of Green and Guidotti.. & Granodiorite of Devonian age. . \\
\hline Aeromagnetic investigations... & Middle or Late Ordovician age. . \\
\hline Albee Formation. & Gravel. \\
\hline Amphibolite...... & Graywacke, Dixville Formation \\
\hline Argillite, rocks of Silurian age & Green Top syncline \\
\hline Arsenopyrite & Greenstone, Albee Formation ........... 19, 21 \\
\hline Asbestos. . . . . & Dixville Formation \\
\hline Aziscohos Formation..... & in Formation. \\
\hline ormation & Heavy metals i \\
\hline Bibliography & Hornfels......... \\
\hline Biotite Gneiss, Dixville Formation & \\
\hline Black Cat anticline & (6) \\
\hline $\begin{array}{l}\text { Black slate member of the Dixville Forma- } \\
\text { tion. }\end{array}$ & Intrusive felsite \\
\hline Boundary Mountain anticlinoriu & Kennebago Member of the Albee Formation.. \\
\hline $\begin{array}{c}\text { Caldwell Facies of the Mansonville Forma- } \\
\text { tion }\end{array}$ & Lamprophyre dikes. \\
\hline ormation & Dixville Formation \\
\hline $\begin{array}{l}\text { Clear Stream Amphibolite Member of the Dix- } \\
\text { ville Formation. }\end{array}$ & $\begin{array}{l}\text { Linear features. } \\
\text { Lisbon Group of Hitchcock. }\end{array}$ \\
\hline an ilations. & $\begin{array}{l}\text { Lobster Lake Formation } \\
\text { Location of report area }\end{array}$ \\
\hline & \\
\hline
\end{tabular}

Deer Mountain Member of the Albee Formation

Deer Mountain syncline.

Dixio Brook Member of the Dixville Formation.

Dixville Formation.

Economic geology

Faults.

Feldspathic quartzite, Albee Formation

Folds, Acadian in pre-Silurian rocks. Acadian in Silurian and Devonian rocks.. major Taconic minor

Foliation igneous rocks

Fossils, general

Bilobia.

Climacograptus bicornis zone

Diambonia

Eccentricosta.

Eoplectodonta.

Plectodonta.

Protospongia sp
Magalloway Member of the Dixville Formation.

Mapping methods.......................... 6

Metaconglomerate, rocks of Silurian age..... 40,43

Metadiorite............................... 52

Metalimestone, rocks of Silurian age.... 41, 42, 44

Metamorphism .............................. 60

Metamorphosed felsic tuff................. 45

Metasiltstone, rocks of Silurian age.......... 46

Metatuff, rocks of Silurian age............. 40

Moose River synclinorium ................... 45, 47

Moretown Formation ..................... 10,11, 14

Ottauquechee Formation

Phyllite, Albee Formation................ 12, 20, 21

Polymict metaconglomerate member of the Rangeley Formation............ $\quad 36$

Polymict metaconglomerate, unnamed Silurian rocks....................... 43

Portage Brook Member of the Albee Formation............................... 12

Poultney Slate_.

Pyroxenite. 
Quartz monzonite.

Quartz-pebble metaconglomerate member of the $R$ : ngeley Formation.

Quartz rods..........................................

Quartzite, Albee Formation

Dixville Formation

rocks of Ordovician and Silurian age

rocks of Silurian age

S1

Serpentinite....................... 50

Slate, Albee Formation................ 12, 18, 19, 20

80

16,19

27

34

40

Rangeley Formation

$\mathbf{3 5}, 36$

Rice Mountain Member of the Dixville Formation. 22

Sand.

unnamed Silurian rocks................. 44

unnamed Silurian and Devonian rocks..- 46

Slate and quartzite member of the Rangeley Formation.......... 38

cleavage

Stowe Formation............ 10,11, 18

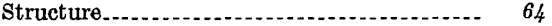

Sulfide mineralization. 80

Taconic unconformity . 64,69

White Mountain Plutonic Series.......... 60 